\title{
1997 Annual Report on Alaska's Mineral Resources
}

\author{
JILL L. SCHNEIDER, Editor
}

\section{U.S. GEOLOGICAL SURVEY CIRCULAR 1154}

Prepared in cooperation with the Bureau of Land Management, Minerals Management Service, National Park Service,

U.S. Fish and Wildlife Service, U.S. Department of Energy, and U.S. Department of Agriculture-Forest Service, as mandated by Section 1011 of the Alaska National Interest Lands Conservation Act, Public Law 96-487, of December 2, 1980

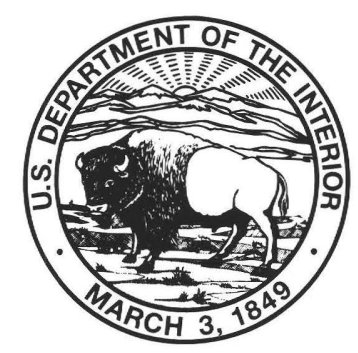

A summary of mineral resource activities in Alaska during 1996 


\title{
U.S. DEPARTMENT OF THE INTERIOR BRUCE BABBITT, Secretary
}

\author{
U.S. GEOLOGICAL SURVEY \\ CHARLES G. GROAT, Director
}

Free on application to the

U.S. Geological Survey, Information Services

Box 25286, Federal Center

Denver, CO 80225

Any use of trade, product, or firm names in this publication is for descriptive purposes only and does not imply endorsement by the U.S. Government

Graphics prepared by Judy Weathers

Cover design by Susan Mayfield 


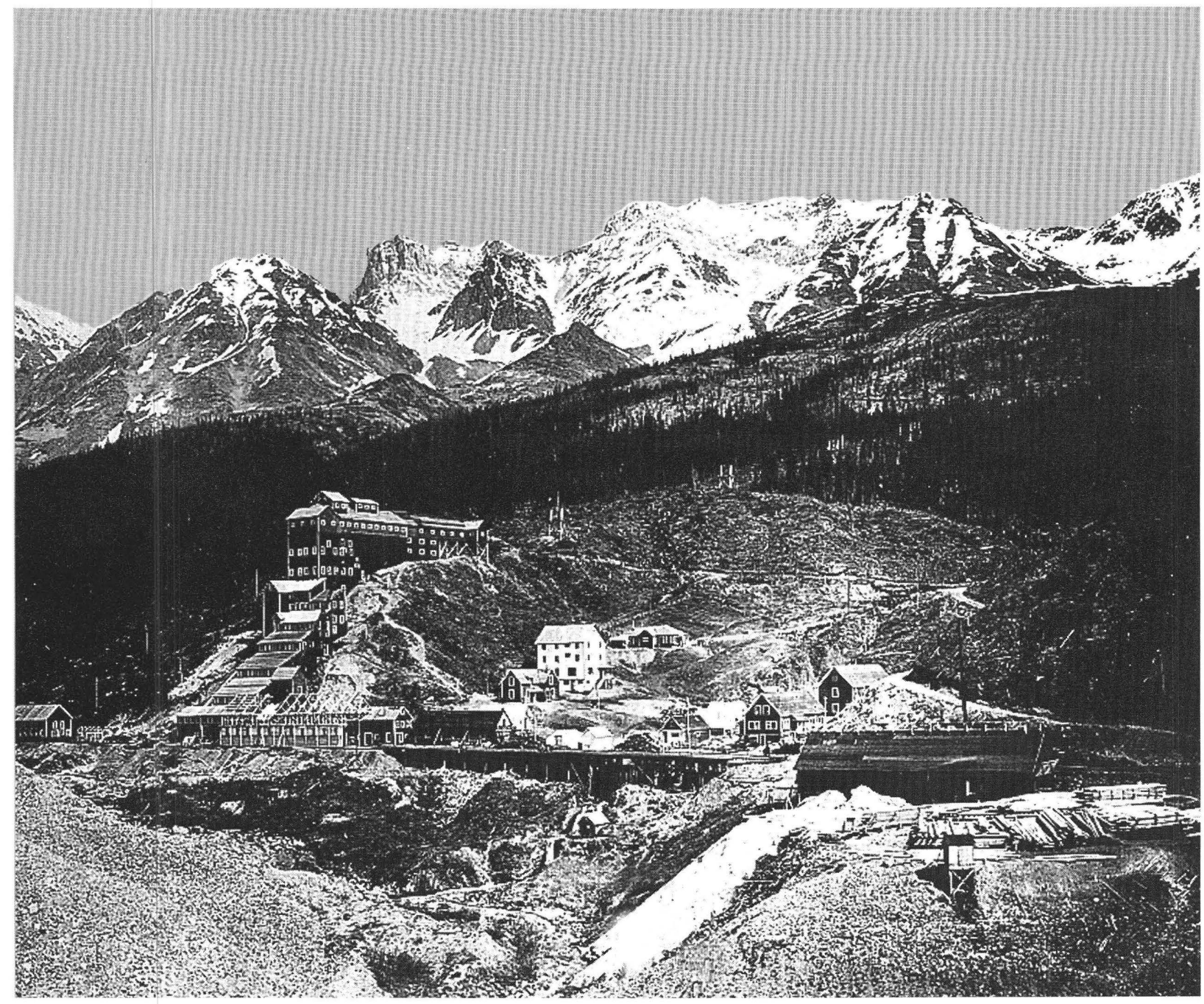

Frontispiece. Kennecott mill and mine area in Wrangell-St. Elias National Park and Preserve. U.S. Geological Survey (USGS) and National Park Service (NPS) geologists are cooperating on a study to evaluate the environmental geochemistry of mineral deposits and mines within the park, in order to provide NPS land managers with baseline information that will allow for better planning of mining and mitigation activities and for the assessment of undiscovered mineral deposits. Photograph from USGS files. 


\section{CONTRIBUTORS}

\section{U.S. DEPARTMENT OF THE INTERIOR}

Bureau of Land Management Donald Baggs

Arthur C. Banet, Jr. Robert Fisk

Minerals Management Service Richard C. Newman

National Park Service Kevin Meyer

U.S. Fish and Wildlife Service Jerald Stroebele

U.S. Geological Survey

Kenneth J. Bird

John P. Galloway Jill L. Schneider Gary D. Stricker Judy G.Weathers

\section{U.S. DEPARTMENT OF ENERGY}

Charles W. Byrer

Robert M. Kornosky

Nelson Rekos

Arden R. Strycker

\section{U.S. DEPARTMENT OF AGRICULTURE} Forest Service

John J. Kato 


\section{CONTENTS}

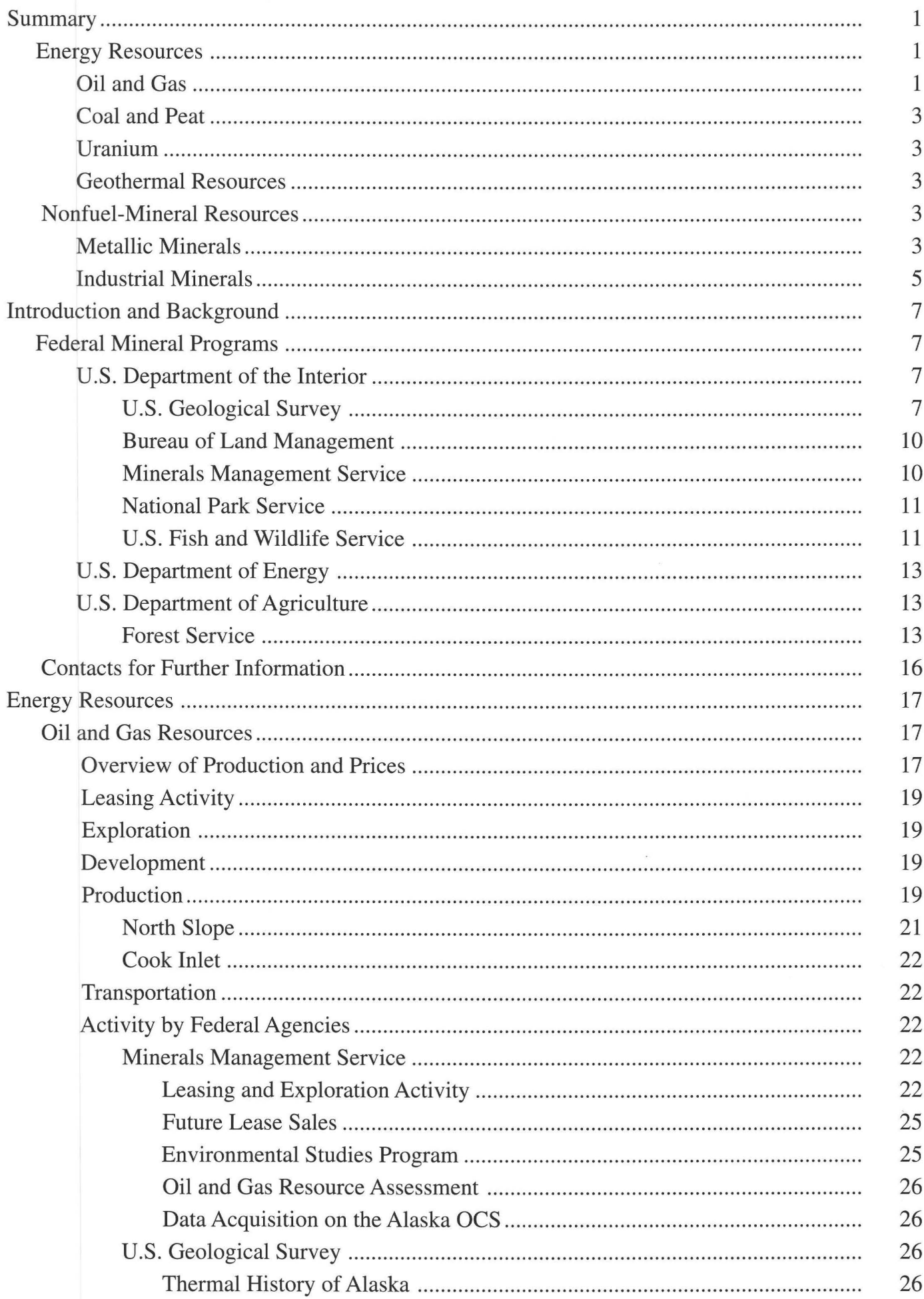


Energy Resources-Continued

Oil and Gas Resources-Continued

Activity by Federal Agencies-Continued

U.S. Geological Survey-Continued

Arctic National Wildlife Refuge

Cooperative Work with Foreign Agencies ...................................................... 26

Cooperative Work with the State of Alaska ................................................... 27

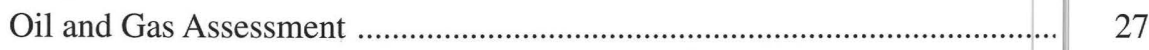

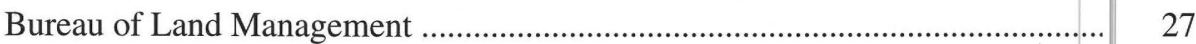

Lease Operations …................................................................................. 28

Resource Evaluation ............................................................................... 28

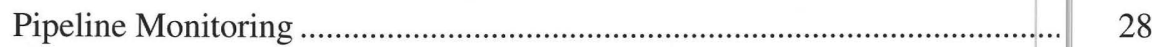

National Park Service ................................................................................... $\quad 30$

U.S. Fish and Wildlife Service ................................................................... 30

Kenai National Wildlife Refuge ................................................................. 30

Activities under Section 1008 of ANILCA .................................................... 30

Resource Activity Impact Assessment ......................................................... 30

Activities under Sections 302 and 303 of ANILCA .................................... 31

Regulation ...................................................................................... 31

Exxon Valdez Oil Spill Restoration Project ……........................................... 31

Arctic National Wildlife Refuge .................................................................. 31

U.S. Department of Energy ............................................................................ 33

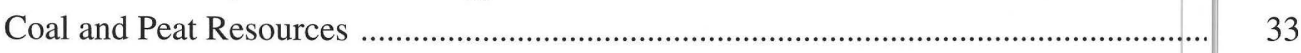

Overview of Production ................................................................................................. 33

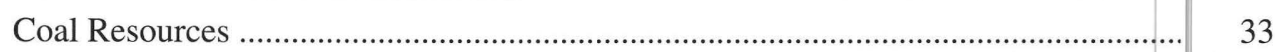

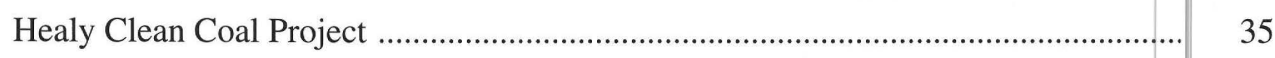

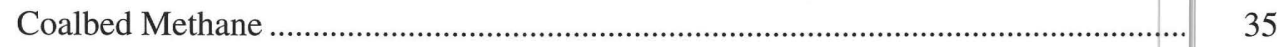

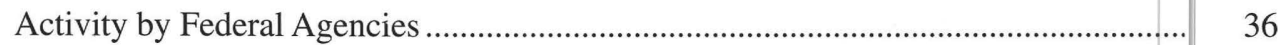

U.S. Geological Survey .................................................................................. 36

U.S. Department of Energy ......................................................................... 36

Healy Clean Coal Project ……………………………………................. 36

Coal-Diesel Project ............................................................................. 37

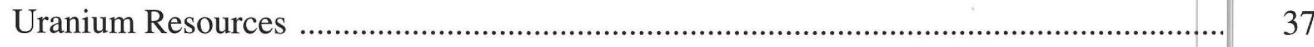

Geothermal Resources ............................................................................................. 37

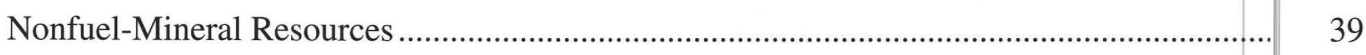

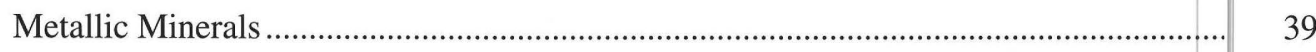

Economic Overview ........................................................................................... 39

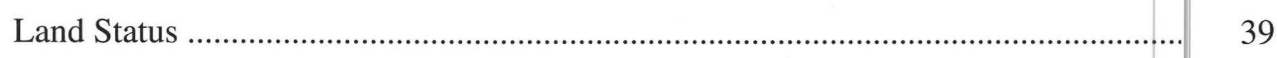

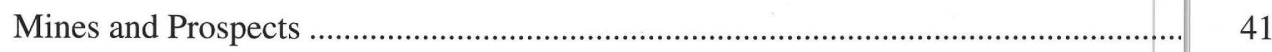

Northern Alaska ............................................................................................ 41

Western and Southwestern Alaska ....................................................................... 41

Fairbanks Mining District ............................................................................. 42

East-Central Alaska ..................................................................................... 42

South-Central Alaska ........................................................................................ 43

Southeastern Alaska ....................................................................................... 43

Activity by Federal Agencies ................................................................................... 43

Interagency Minerals Coordinating Group ...................................................... 43

U.S. Geological Survey ......................................................................... 44 
Nonfuel-Mineral Resources-Continued

Metallic Minerals-Continued

Activity by Federal Agencies - Continued

U.S. Geological Survey-Continued

Mineral-Resource Assessments ..................................................................... 44

Environmental Studies ............................................................................. 47

Cooperative Work with Federal Agencies ................................................... 48

Cooperative Work with the State of Alaska .................................................... 49

Cooperative Work with Alaska Native Corporations ....................................... 49

Cooperative Work with Foreign Scientific Agencies ..................................... 49

Bureau of Land Management ........................................................................ 49

Mining Claim Management ........................................................................ 49

Cooperative Work with the Forest Service ................................................... 51

Other Activities ........................................................................................... 51

National Park Service ................................................................................ 52

Mineral Lands Management ................................................................ 52

Abandoned Mineral Lands Reclamation .................................................... 53

AMRAP Authorizations ............................................................................ 54

U.S. Fish and Wildlife Service .......................................................................... 54

Forest Service …...................................................................................... 55

Minerals Development on NFS Lands ..................................................... 55

Mineral Patent and Validity Examinations .................................................. 55

Exploration on NFS Lands ..................................................................... 56

Cooperative Work with the BLM .............................................................. 56

Industrial Minerals .................................................................................................... 56

Economic Overview ..................................................................................... 56

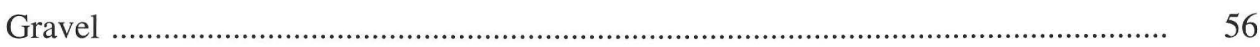

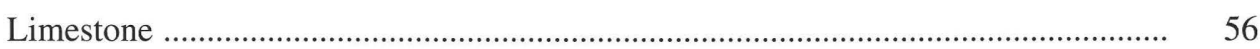

Granite ............................................................................................ 56

Activity by Federal Agencies .......................................................................... 57

U.S. Geological Survey ............................................................................... 57

Bureau of Land Management ............................................................................ 57

U.S. Fish and Wildlife Service ........................................................................... 57

Forest Service ….............................................................................. 58

Selected References ..................................................................................................... 59

Appendix 1. Roles of Federal Agencies in Mineral Programs ................................................ 67

U.S. Department of the Interior .................................................................................... 67

U.S. Geological Survey ................................................................................. 67

Bureau of Land Management .............................................................................. 67

Minerals Management Service .............................................................................. 68

National Park Service ........................................................................................ 68

U.S. Fish and Wildlife Service ........................................................................ 69

U.S. Department of Energy ................................................................................................ 69

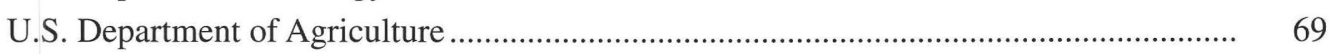

Forest Service ............................................................................................... 69

Appendix 2. Listing of USGS Circulars in ANILCA Section 1011 Annual Mineral Report

Series 


\section{FIGURES}

Frontispiece. Photograph of Kennecott mill and mine area in Wrangell-St. Elias

National Park and Preserve

1. Map of Federal land ownership in Alaska

2. Photograph of USGS geologist mapping gold prospect on Alaska Peninsula

3. Map of National Park System units in Alaska

4. Map of national wildlife refuges in Alaska

5. Map of Forest Service ranger districts in Alaska

6. Graph showing fluctuation in Alaska North Slope crude oil prices for 1996

7. Graph showing fluctuation in annual average price of Alaska North Slope crude oil, 1988-1996

8. Map showing locations of 1996 exploratory oil wells, known oil and gas fields, and possible petroleum-bearing sedimentary basins

9. Map showing Alaska Region OCS planning areas, lease sale history, and location of OCS Lease Sale 144

10. Photograph of Aleutian Range and Big River Valley on Alaska Peninsula

11. Map showing selected Federal land units

12. Photograph of stream-gaging station on Little Black River in Yukon Flats National Wildlife Refuge

13. Map showing areas of potential coal, uranium, and geothermal resources; industry activities; and agency activities

14. Photograph of coal seams in Nenana coal field

15. Map showing locations of nonfuel metallic-mineral mines and deposits and areas of significant industry activity in 1996

16. Map showing locations of 1996 USGS regional and topical studies listed in Table 10 .....

17. Map showing status of USGS AMRAP quadrangle studies as of January 1997

18. Photograph of USGS geologists at Hirst-Chichagof Mine on Chichagof Island

19. Map showing locations of 1996 active Federal mineral patent case files

20. Photograph of BLM geologist at abandoned Ronan Mine north of Hyder

21. Photograph of NPS soil cleanup in Yukon-Charley Rivers National Preserve

22. Photograph of Kennel Creek limestone on northeastern Chichagof Island

\section{TABLES}

1. 1996 Alaskan oil and gas production statistics

2. Oil and gas production in Alaska, 1902-1996

3. Alaska exploratory oil wells drilled on Federal and State lands in 1996

4. Proceeds from lease sales on Alaska Region OCS planning areas, 1976-1996

5. Alaska Region OCS leases and wells drilled, 1976-1996

6. Producible oil leases, Beaufort Sea planning area, as of December 31, 1996

7. Proposed activity for Alaska Region OCS planning areas, 1997-2002 .....

8. FWS Letters of Authorization issued in 1996

9. Mining production in Alaska, 1993-1996.

10. USGS regional and topical studies in 1996 


\section{INTERNATIONAL SYSTEM OF UNITS (SI) CONVERSION TABLE ${ }^{1}$}

\begin{tabular}{|c|c|c|}
\hline To convert from & to & divide by \\
\hline cubic meter & cubic foot (gas) & 0.02831685 \\
\hline cubic meter & cubic yard & 0.7645549 \\
\hline degree Celsius & degree Fahrenheit & $t^{\circ} \mathrm{F}=32+\left(1.8 \times t^{\circ} \mathrm{C}\right)$ \\
\hline gram & troy ounce & 31.10348 \\
\hline kilocalories per kilogram ${ }^{2}$ & Btu per pound & 0.556 \\
\hline liter & gallon & 3.785 \\
\hline meter & foot & 0.3048 \\
\hline kilogram & pound & 0.4535924 \\
\hline kilogram & troy ounce & 0.03110348 \\
\hline kilometer & mile & 1.609347 \\
\hline metric ton & ton (short) & 0.9071847 \\
\hline square kilometer & acre & 0.004046873 \\
\hline square kilometer & square mile & 2.589998 \\
\hline
\end{tabular}

\footnotetext{
${ }^{1}$ American Society for Testing and Materials (1980)

${ }^{2}$ Weast (1974, p. F-284)
} 


\section{ACRONYMS AND ABBREVIATIONS}

ACE

ADEC

ADGGS

ADNR

AESP

AIDEA

AIM

A-J

AMHT

AML

AMRAP

ANILCA

AOGCC

ARCO-Ak

ARDF

ARLIS

$\mathrm{bbl} / \mathrm{d}$

BLM

$\mathrm{BPX}$

BPX-Ak

CFR

COST

CWA

DOE

DOI

EIS

EPA

ERP

FS

FWS

GIS

GPS

I\&E

IMCG

JPO

LOA

MAS

MILS
U.S. Army Corps of Engineers

Alaska Department of Environmental Conservation

Alaska Division of Geological and Geophysical Surveys

Alaska Department of Natural Resources

Alaska Environmental Studies Program

Alaska Industrial Development and Export Authority

Abandoned and Inactive Mines

Alaska-Juneau

Alaska Mental Health Trust

abandoned mine lands

Alaska Mineral Resource Assessment Program

Alaska National Interest Lands Conservation Act

Alaska Oil and Gas Conservation Commission

ARCO Alaska

Alaskan Resource Data File

Alaska Resources Library and Information Services

barrels per day (of oil)

Bureau of Land Management

BP Exploration, Inc.

BP Exploration Alaska

Code of Federal Regulations

continental offshore stratigraphic test

Clean Water Act of 1977

U.S. Department of Energy

U.S. Department of the Interior

Environmental Impact Statement

Environmental Protection Agency

Energy Resources Program

U.S. Department of Agriculture, Forest Service

U.S. Fish and Wildlife Service

geographic information system

Global Positioning System

Inspection and Enforcement

Interagency Minerals Coordinating Group

Joint Pipeline Office

Letter of Authorization

Minerals Availability System

Minerals Industry Location System 


$\begin{array}{ll}\text { MMS } & \text { Minerals Management Service } \\ \text { MRDS } & \text { Mineral Resources Data System } \\ \text { MRP } & \text { Mineral Resources Program } \\ \text { NGL } & \text { natural gas liquid } \\ \text { NFS } & \text { National Forest System } \\ \text { NP\&P } & \text { National Park and Preserve } \\ \text { NPRA } & \text { National Petroleum Reserve-Alaska } \\ \text { NPS } & \text { National Park Service } \\ \text { NTIS } & \text { National Technical Information Services } \\ \text { NWR } & \text { National Wildlife Refuge } \\ \text { OCS } & \text { Outer Continental Shelf } \\ \text { SAMRAP } & \text { State of Alaska Mineral Resource Assessment project } \\ \text { TAPS } & \text { Trans-Alaska Pipeline System } \\ \text { UAF } & \text { University of Alaska-Fairbanks } \\ \text { USBM } & \text { U.S. Bureau of Mines } \\ \text { USC } & \text { United States Code } \\ \text { USGS } & \text { U.S. Geological Survey }\end{array}$





\title{
1997 ANNUAL REPORT ON ALASKA'S MINERAL RESOURCES
}

\author{
Jill L. Schneider, Editor \\ - SUMMARY-
}

Section 1011 of the Alaska National Interest Lands Conservation Act (ANILCA) of 1980, as amended, requires that "On or before October 1, 1982, and annually thereafter, the President shall transmit to the Congress all pertinent public information relating to minerals in Alaska gathered by the United States Geological Surveys, United States Bureau of Mines, and any other Federal agency" [16 USC 3151]. This is the sixteenth annual report that has been prepared in response to that requirement; current Alaskan mineral projects and events that occurred during 1996 are summarized. For the purpose of this document, the term "minerals" encompasses both energy resources (oil and gas, coal and peat, uranium, and geothermal) and nonfuelmineral resources (metallic and industrial minerals).

The U.S. Geological Survey (USGS), Bureau of Land Management (BLM), and Minerals Management Service (MMS) were the principal Federal agencies that published information about energy and mineral resources in Alaska in 1996, and their activities are detailed in this report. Additional agencies in the U.S. Department of the Interior (DOI) that contributed to this document are the National Park Service (NPS) and U.S. Fish and Wildlife Service (FWS); the U.S. Department of Energy (DOE) and U.S. Department of Agriculture, Forest Service (FS), also reported on their respective mineral activities. Other sources of public information for this report include State publications, trade and professional journals, presentations at public meetings, and press releases.

This report addresses both onshore and offshore areas of Alaska.

\section{ENERGY RESOURCES}

\section{OIL AND GAS}

Alaskan production of oil and natural gas liquids totaled 544 million barrels in 1996, a decrease of 5 percent from 1995 levels; production has declined annually since

Manuscript approved for publication October 21, 1997. the peak total of 760 million barrels in 1988. Dry natural gas production in 1996 totaled 5.23 billion cubic meters, a 2-percent increase from 1995. Alaska provided about 25 percent of total United States oil production in 1996 and, of the 50 states, ranked tenth in revenues from Federal oil and gas leases. North Slope oil prices during the year averaged \$19.86 per barrel, an 18-percent increase from the previous year and the highest since 1990.

After the Federal ban on North Slope oil exports was lifted in early 1996, BP Exploration Alaska contracted to ship 3.65 million barrels of crude oil to Taiwan. The oil industry and Federal and State agencies continued to cooperate in establishing the Alaska Energy InfoBank, a centralized repository for all nonproprietary oil and gas data shared by those entities.

Three lease sales were held. The MMS held Lease Sale 144 in the Beaufort Sea planning area, the first Federal lease sale on the Alaska Outer Continental Shelf (OCS) since 1991; total high bids were $\$ 14.4$ million for 29 tracts covering 405 square kilometers. The State of Alaska held two lease sales, one on the North Slope and one in the Cook Inlet region; combined total high bids were \$5.1 million for 49 tracts comprising 728 square kilometers.

The Alaska Oil and Gas Conservation Commission issued 203 drilling permits in 1996, a 6-percent decrease from 1995. A total of 12 exploratory wells were active during 1996, three more than the previous year; 140 development wells and 18 service wells were also drilled. Seismic surveys were conducted in Cook Inlet and on the North Slope. On the North Slope, discovery of the Alpine Oil Field was announced, and the Badami and Northstar fields were slated for development.

North Slope fields produced 97 percent of Alaska's oil and natural gas liquids during 1996. The Prudhoe Bay and Kuparuk River fields were the two most productive oil fields in the United States, yielding 19 percent of national production. The Cascade pool of the Niakuk field began production. The Cook Inlet region produced 99 percent of the State's dry natural gas. Alyeska Alloys planned to build a production facility in Tyonek that would use Cook Inlet natural gas to produce iron carbide from iron ore.

The Trans-Alaskan Pipeline System (TAPS) transported 1.4 million barrels of North Slope crude oil per 
day in 1996, but 3 of the line's 12 pump stations were shut down as a cost-cutting measure. A pipeline to connect the Alpine field to TAPS was designed. Yukon Pacific Corporation continued to promote its proposed trans-Alaska gas pipeline to carry natural gas from the North Slope to Valdez.

The State of Alaska received $\$ 18.35$ million in minerals revenues collected by the MMS from both onshore and offshore Federal leases. At year's end, the oil industry held 80 active leases on the Alaska OCS, all in the Beaufort Sea planning area. The MMS released its final proposal for the next 5-year (1997-2002) leasing program: leasing will be considered in the Beaufort Sea, Chukchi Sea and Hope Basin, Lower Cook Inlet, and Gulf of Alaska/Yakutat planning areas. The MMS Alaska Environmental Studies Program continued to monitor the possible effects of oil and gas exploration or drilling after lease sales. The MMS published a new assessment of the hydrocarbon resources of Alaska OCS lands.

Petroleum research by the USGS is aimed at onshore oil and gas resources. In 1996, the USGS released a map and companion report on the thermal maturity of rocks and thermal history of sedimentary basins in Alaska; the study provides a framework for the estimation of hydrocarbon potential in the State. Geologic mapping and sampling were conducted in the Arctic National Wildlife Refuge (Arctic NWR) for a new evaluation of the oil and gas potential underlying the refuge. The USGS formally agreed to participate with private industry and the Geological Survey of Canada in a project to evaluate the potential for gas-hydrate production in the Arctic and worked with the Alaska Division of Geological and Geophysical Surveys (ADGGS) to assess the petroleum potential of possible reservoir rocks in the northern foothills of the western Brooks Range. A report on the economics of undiscovered oil and gas resources in Alaska was released.

The BLM managed lease agreements and governed leasehold operations for 37 producing oil and gas leases and a Compensatory Royalty Agreement on the Kenai Peninsula. The BLM also administered 126 nonproducing oil and gas leases in central and western Alaska. Five applications for drilling permits on the Kenai NWR were processed; two exploratory wells were completed.

BLM investigations showed that oils from three distinct petroleum systems are present under the Arctic NWR Coastal Plain. The BLM provided data for a USGS assessment of Coastal Plain reserves and compiled maps for the FWS showing caribou calving areas in relation to areas of potential oil and gas resources. The BLM responded to inquiries for information on oil and gas leasing in the National Petroleum Reserve-Alaska (NPRA) and advised the FWS on the assessment of leasable minerals in the Yukon Flats NWR.
The Joint Pipeline Office (JPO) is a cooperative effort between the BLM and 10 other Federal and State agencies to monitor TAPS. The JPO reviewed an application for the Alpine development pipeline on the North Slope, coordinated cleanup for an oil leak at TAPS Pump Station 10 , and investigated the cause and effect of audible shocks and ground shaking emanating from TAPS in the Thompson Pass area north of Valdez. The JPO received the Alaska Governor's Excellence in Government Service Award for its Compliance Monitoring program.

The NPS provided comments to the MMS on the draft Environmental Impact Statement (EIS) for the proposed OCS Oil and Gas Leasing Program, 1997-2002. Potentially affected lands include the Aniakchak, Bering Land Bridge, Cape Krusenstern, Glacier Bay, Katmai, and Kenai Fjords units of the National Park System in Alaska.

During 1996, the FWS maintained oversight for remedial cleanup programs in the Beaver Creek and Swanson River Oil Fields of the Kenai NWR and issued eight specialuse permits for exploration activities on the Alaska Maritime, Arctic, and Izembek NWR's. For oil and gas activities off refuge lands, the FWS reviewed 28 permit applications to the U.S. Army Corps of Engineers (ACE). The FWS also conducted one informal consultation for TAPS under Section 7 of the Endangered Species Act. Reviews and comments were provided for two Federal OCS leasing plans and three proposed State oil and gas lease sales.

Research on airborne metal and hydrocarbon contamination continued on the North Slope. Water resources inventories and assessments were continued on the Kenai and Yukon Flats NWR's in order to reserve water rights for fish and wildlife purposes in areas of possible oil and gas activities. Stream gaging stations were installed on the Becharof and Innoko NWR's for other mineral-related concerns. One FWS ruling concerning the incidental take of marine mammals during specified activities was in effect for the Beaufort Sea and coastal Alaska in 1996, and nine Letters of Authorization were issued under this ruling. The FWS issued an authorization to allow polar bear deterrence during oil and gas activities in the same area.

The FWS also pursued its continuing wildlife and related studies on the Coastal Plain of the Arctic NWR. Eleven applications were filed with the State of Alaska for water rights on selected lakes within the Coastal Plain.

Work continued on DOE's cooperative research and development agreement with BP Exploration, Inc. (BPX) to develop a process to recover heavy oil from the Prudhoe Bay Oil Field; laboratory studies to characterize the oil's physical properties were conducted at the DOE's National Institute for Petroleum and Energy Research in Bartlesville, Oklahoma. BPX is funding 78 percent of the $\$ 6.3$-million project and will undertake a pilot study if an economically viable recovery process is developed. 


\section{COAL AND PEAT}

Alaskan coal production decreased 11 percent in 1996 to 1.3 million metric tons, valued at $\$ 38$ million; peat production increased 9 percent to 29,053 cubic meters, valued at $\$ 175,000$. Coal and peat combined represented 6.4 percent of total mining production value. The Usibelli Mine near Healy produced all commercial Alaskan coal; half of this was used for in-state power generation, and the other half was exported overseas.

Other coal resources in Alaska include the Kuchiak Research Mine on the western North Slope, the Matanuska Coal Field northeast of Anchorage, and the Beluga Coal Field west of Cook Inlet. In the Matanuska Coal Field, the Alaska Office of Surface Mining issued a permit to Nerox Power Systems to reopen the underground Jonesville Mine near Sutton, and Usibelli Coal acquired an option to purchase the Wishbone Hill project from North Pacific Mining. Two companies hold State-owned leases in the Beluga Coal Field and plan to develop the field if anticipated improvements are made to the existing dock at Tyonek. Matanuska Energy proposed to produce coalbed methane gas in the Houston area of south-central Alaska and conducted studies to determine additional rural areas that could benefit from this energy source.

The USGS continued research on the coal-bearing formations of the Kenai Group in south-central Alaska. Personnel also continued studies to quantify Alaska's coal resources for inclusion in the next National assessment.

The Healy Clean Coal Project is one of 40 DOEsponsored projects in the United States being built to demonstrate new, clean-burning coal technologies that limit the emission of pollutants commonly cited as a cause of acid rain. The DOE issued the Healy project's Final EIS in December 1993, signed a Record of Decision in March 1994, and is providing $\$ 117.3$ million in Federal funding for design, permitting, construction, and operation of the project. Construction of the 50-megawatt power plant continued in 1996; full commercial operation was slated for mid-1999. The \$267.2-million project is funded by the DOE and the Alaska Industrial Development and Export Authority (AIDEA).

The Coal-Diesel Project at the University of Alaska-Fairbanks (UAF) is the second DOE-sponsored project in Alaska. Project managers plan to install a 4.2megawatt electrical generator at UAF that will burn a coalwater slurry and be 15 percent more efficient than conventional oil-fired boilers. An Environmental Information Volume was prepared in 1996, and the permitting process was expected to be completed by mid1997. The \$44.6-milllion project is being funded by DOE, UAF, Alaska Science and Technology Foundation, and Usibelli Coal.

\section{URANIUM}

Limited exploration continued at the Bokan Mountain uranium claims in southeastern Alaska. The USGS summarized environmental concerns associated with the deposit.

\section{GEOTHERMAL RESOURCES}

State geothermal leases are still active in the Makushin Valley area in the Aleutian Islands, but no development has occurred. Geothermally heated greenhouses are being operated at Circle Hot Springs and Manley Hot Springs. No Federal geothermal research was funded in 1996.

\section{NONFUEL-MINERAL RESOURCES}

\section{METALLIC MINERALS}

The value of Alaska's mining industry exceeded \$1 billion in 1996, an increase of 43 percent over 1995; this included production estimates of $\$ 590$ million, development costs of $\$ 393.8$ million, and exploration expenditures of $\$ 44.5$ million. Metallic minerals comprised 84 percent of total mining production value, and copper values were reported for the first time in 40 years. The five major metallic minerals produced in Alaska were zinc ( $\$ 361.6$ million), gold (\$62.6 million), lead (\$52.3 million), silver (\$19.1 million), and copper ( $\$ 0.8$ million); copper was produced as a byproduct from both the Greens Creek polymetallic mine and Nixon Fork gold mine. The mining industry employed 3,760 people in Alaska in 1996, an increase of 10 percent. There were 9,642 Federal and 38,700 State mining claims registered in Alaska in 1996.

The Fort Knox gold mine near Fairbanks opened, and the Greens Creek silver-lead-zinc mine in southeastern Alaska reopened. Cominco Alaska initiated upgrades to the DeLong Mountains Transportation System, which connects the Red Dog Mine to the port on Kotzebue Sound. Construction began at the Illinois Creek gold-silver mine in western Alaska, and development of the Kensington gold property continued in southeastern Alaska. Exploration for lode-gold deposits occurred on the Seward Peninsula, at Donlin Creek in western Alaska, at True North, Golden Summit, and Ester Dome in the Fairbanks area, and at Stone Boy in east-central Alaska.

A Federal-State Interagency Minerals Coordinating Group (IMCG) was formed in March 1996 to address coordination of mineral activities in Alaska by IMCG members USGS, BLM, FS, and ADGGS. The agencies created a 5-year plan for mineral-resource assessments and produced a prototype of an Internet-accessible bibliographic data base. 
The USGS continued its program of geologic mapping and assessment of undiscovered mineral resources. A draft report on the statewide mineral-resource assessment was completed, and seven quadrangle-scale subsets of the Alaska Resource Data File were published. Regional assessments were underway for the Alaska Peninsula, eastern Alaska Range and east-central Alaska, west-central Alaska, and southeastern Alaska; aeromagnetic and gravity maps for Interior Alaska were published in conjunction with the State. Geologic maps for the Craig, Dixon Entrance, and Killik River quadrangles, and resource assessments for the Chandler Lake, Survey Pass, Port Moller, Stepovak Bay, and Simeonof Island quadrangles, were published. A study of geology, mineral deposits, and mining history of the Fortymile Mining District was also published. The annual report of current USGS activities in Alaska was compiled. Regional environmental geochemistry studies focused on mercury deposits in southwestern Alaska, acid mine drainage in southeastern Alaska, and mineral deposits in Wrangell-St. Elias National Park and Preserve (NP\&P). A volume describing research results of USGS environmental studies on mineral deposits in Alaska was published.

The USGS conducted cooperative studies with Federal, State, Native, and foreign entities. At WrangellSt. Elias NP\&P, the USGS and NPS worked to evaluate the environmental geochemistry of mineral deposits, active mines, and abandoned mine lands within the park. A geologic map was compiled for the FS ecosystem study of northeastern Chichagof Island. The USGS worked with the ADGGS to map and evaluate the Rampart Mining District. The USGS also worked with the Calista Corporation to assess the mineral resources of Native lands in southwestern Alaska and collaborated with scientists from Russia, Alaska, and Canada to compile mineral deposit data and a metallogenic map for lands of the circum-North Pacific.

The BLM accepted 952 new Federal mining claims during fiscal 1996; total recorded claims was 9,642. The BLM also processed 64 Plans of Operations and 131 Notices of Intent and conducted 353 site inspections to ensure operator compliance with permitted mining activities. Field examinations were conducted for four mineral patent applications, and eight mineral patent reports were reviewed; one patent was issued. The BLM also completed 103 mineral reports for land-use planning.

The BLM Reclamation Standards working group initiated projects to evaluate specific reclamation methods. Final regulations were issued governing occupancy of mining claims. A preliminary inventory of abandoned mine lands in Alaska was initiated, using mineral-information data bases and case files. In the Tongass National Forest, the BLM continued its evaluation of the mineral resources of the Sitka and Hoonah Ranger Districts, began a similar study for the Stikine Area, and continued its evaluation of abandoned mine sites throughout the Tongass. Fieldwork was completed on the geologic guide for the Taylor Highway-Fortymile Wild and Scenic River area. The Campbell Creek Science Center at the BLM's Campbell Tract in Anchorage was dedicated in November 1996.

The NPS reviewed nine proposed mining Plans of Operations for Denali and Wrangell-St. Elias NP\&P's; no Plans were approved. Two mining operations were under permit, one in Bering Land Bridge National Preserve and one in Wrangell-St. Elias NP\&P; only minimal activity occurred at the sites. NPS geologists conducted two mineral validity field examinations and completed three mineral validity reports for claims in Denali and Wrangell-St. Elias NP\&P's. NPS cultural resource specialists continued to compile the cultural landscape inventory of historic mining camps and operations in the Gold Hill-Chisana Historic Mining District in Wrangell-St. Elias NP\&P and completed a draft report on 344 archeological sites in Denali NP\&P. Land surveys were conducted to determine the boundaries of 32 patented and unpatented claims within Wrangell-St. Elias NP\&P.

Under the NPS Mineral Land Restoration program, three adits and one trench were closed in Kenai Fjords National Park, and plans were developed to close an adit in Denali NP\&P. Also in Denali NP\&P, land recontouring was initiated at the Red Top Mine mill site, and field data were collected in preparation for future reclamation work on Slate Creek. Restored stream channels and revegetated flood plains were monitored for stability at the Glen Creek placer mine reclamation project in Denali NP\&P. Under an NPS hazardous waste remediation program, 15.3 cubic meters of contaminated soils on a former mining property in YukonCharley Rivers National Preserve was cleaned, contaminated soils were scheduled for removal from a former mining property in Kenai Fjords National Park, and mine tailings at the Nabesna Mine mill site in Wrangell-St. Elias NP\&P were evaluated. No permits were issued for Federal mineral assessment activities in Alaska park units.

In 1996, there were 56 active mining claims on 5 of the 16 national wildlife refuges in Alaska. The FWS reviewed 56 ACE permit applications for mining-related activities off refuges, mining plans for the Illinois Creek Mine, and task reports on the Alaska-Juneau and Kensington mines for the Environmental Protection Agency (EPA). The FWS also monitored the start-up of the Fort Knox Mine in Fairbanks.

The FS received 22 Notices of Intent and 120 Plans of Operations for mineral activities in Alaska's national forests in 1996. The Greens Creek Exchange Act became law in 1996, allowing underground access to lands adjacent to Greens Creek Mine patented claims, in return for royalty payments and land transfers by the mine's owner. The FS initiated a supplement to the Final EIS of the Kensington gold project in order to analyze proposed changes to the 
approved Plan of Operations. Two mineral reports for patent applications were in preparation, and two revised reports were resubmitted for adjudication. Inventories of environmental and safety hazards on abandoned and inactive mining claims were in progress on the Tongass National Forest.

\section{INDUSTRIAL MINERALS}

The combined value of Alaska's industrial minerals comprised 10 percent of total mineral production in 1996. The value of sand, gravel, and building stone production rose 9 percent in 1996 to $\$ 58.1$ million; jade and soapstone production value were level with 1995 production at $\$ 25,000$. Sealaska Corporation applied for State and Federal permits to operate an open-pit limestone quarry on northern
Prince of Wales Island.

The USGS began to assess the limestone resources of Chichagof Island for the Tongass National Forest and published a map of surficial deposits found in northeastern Anchorage. The BLM began work on a project for the FS to survey the industrial minerals of the Chugach National Forest in south-central Alaska. Mapping, sampling, and geophysical surveys were used to determine quantity and quality of aggregate, building stone, and other mineral materials.

The FWS made 14 gravel sales on the Alaska Maritime, Arctic, Izembek, and Yukon Delta NWR's in 1996. The FS disposed of 1.6 million cubic meters of sand, gravel, and quarried stone through in-service use, material sales, and Free-Use Permits. Primary use for these commodities is in the construction of State of Alaska public roads, timber-sale roads, breakwaters, airports, and other large public-use projects. 


\section{INTRODUCTION AND BACKGROUND}

Section 1011 of the Alaska National Interest Lands Conservation Act (ANILCA) of 1980, as amended, required that "On or before October 1, 1982, and annually thereafter, the President shall transmit to the Congress all pertinent public information relating to minerals in Alaska gathered by the United States Geological Surveys, United States Bureau of Mines, and any other Federal agency" [16 USC 3151]. The U.S. Geological Survey (USGS) subsequently was delegated as the lead agency in responding to this requirement. In 1996, the U.S. Bureau of Mines (USBM) was defunded as a Federal agency, and the personnel and programs of the USBM Alaska Field Operations Center were transferred to the Alaska Office of the Bureau of Land Management (BLM).

In 1996, the USGS and the BLM were the principal Federal agencies that generated information about onshore mineral resources in Alaska; the Minerals Management Service (MMS) was the prime agency reporting on resource activities in Alaska's coastal waters. Their data, analyses, and reports were used in-house and by other agencies for resolving questions on land use, access, environmental impacts, and mining claim evaluation. Additional Federal agencies that contributed to this report were the National Park Service (NPS) and U.S. Fish and Wildlife Service (FWS) in the U.S. Department of the Interior (DOI); the U.S. Department of Energy (DOE); and the U.S. Department of Agriculture, Forest Service (FS). Current mineral programs of these agencies are outlined below, and agency roles and guidelines related to mineral programs are discussed in appendix 1. The distribution of lands under Federal management is shown in figure 1.

This circular is the sixteenth in its series (see appendix 2). The report summarizes information made public in 1996 and early 1997 for the two broad categories of "minerals": energy resources (oil, gas, coal, peat, uranium, and geothermal) and nonfuel-mineral resources (metallic and industrial minerals). As used herein, the term "public information" includes results of Federal projects as published in government reports and professional and trade journals; oral presentations by representatives of Federal and State agencies and industry at symposia, conferences, and other public forums; conference proceedings volumes; and press releases. Data from the State's annual summaries on Alaska's oil and mining industries are cited in parts of this circular. Papers cited in the text and other recently published reports pertinent to Alaska's mineral resources are listed in the "Selected References" section of this document.

\section{FEDERAL MINERAL PROGRAMS}

\section{U.S. DEPARTMENT OF THE INTERIOR}

\section{U.S. GEOLOGICAL SURVEY}

In 1980, Section 1010 of ANILCA established the Alaska Mineral Resource Assessment Program (AMRAP) and directed the Secretary of the Interior to "assess the oil, gas, and other mineral potential on all public lands in the State of Alaska in order to expand the data base with respect to the mineral potential of such lands." To assist in meeting the mandate of AMRAP, the USGS entered upon a systematic investigation of Alaska's energy and nonfuelmineral resources through four progressively more detailed levels of statewide, regional, quadrangle-based, and topical studies. This program of studies continued in 1996.

The USGS performed fieldwork and laboratory research in support of resource assessments in Alaska through two programs in 1996: (1) the Mineral Resources Program (MRP), which included studies of undiscovered mineral resources on public lands, development of assessment techniques, mineral-environmental investigations, and studies of mineral deposit genesis; and (2) the Energy Resources Program (ERP), which included studies of petroleum-forming processes and potential source regions, in order to produce reliable estimates of undiscovered petroleum resources. The mineral-resource aspects of these programs are more fully described in later sections of this report.

USGS research is essential for determining the distribution and potential of national mineral and energy endowments, for formulating public policy affecting resource and land management, for improving resourceassessment technology, and for minimizing potential impacts from development. These studies also develop the concepts, models, and techniques needed to identify new energy resources and mineral deposits, tools which are indispensable to the earth-resources exploration industries.

USGS publications are a critical source of information about Alaska's geology and mineral resources. Statewide geologic investigations are published at the $1: 1,000,000$ scale; regional studies at the $1: 500,000$ scale. Investigations at the quadrangle level draw on many geologic disciplines to produce resource assessments at scales of 1:250,000 and 1:125,000 (fig. 2). Topical research focuses 


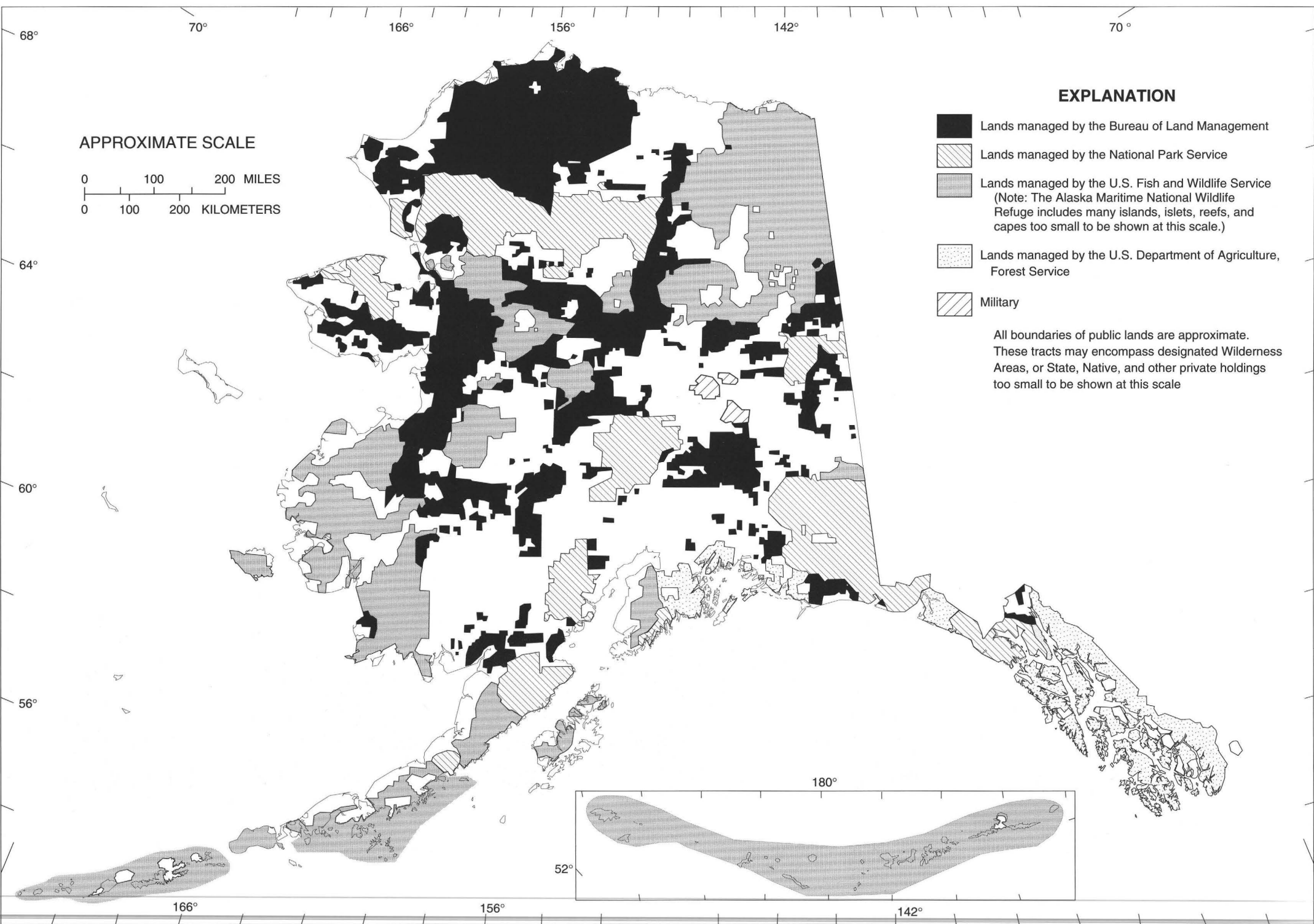


on detailed studies of oil and gas provinces and mining districts, specific oil fields and mineral deposits, or questions relating to the genesis of petroleum plays and mineral deposits. In 1996, 22 MRP and 4 ERP studies were in progress.

The USGS Mineral Resources Data System (MRDS) is a digital data base of mineral deposits and occurrences in the United States and worldwide. Each MRDS record includes up to 200 pieces of information related to a site's geographic location, geology, commodity, deposit type, known exploration and development, mine workings, production, reserves, resources, and references. In Alaska, there are 4,156 records for deposits and occurrences in 100 1:250,000-scale quadrangles (Leonard and Huber, 1987). Further information on MRDS can be obtained from Bruce Lipin, MRDS Project Chief, U.S. Geological Survey, 954 National Center, Reston, VA 22092 0001. In 1992, Alaska records in the MRDS files were extracted, refined, and compiled into the Alaska Resource Data File (ARDF); additional records have also been incorporated into the data base. Information on ARDF can be obtained from Frederic Wilson at the USGS office in Anchorage, Alaska.

Geologic information from the MRDS files can be used to complement data from the Minerals Availability System (MAS), which contains information on reserve

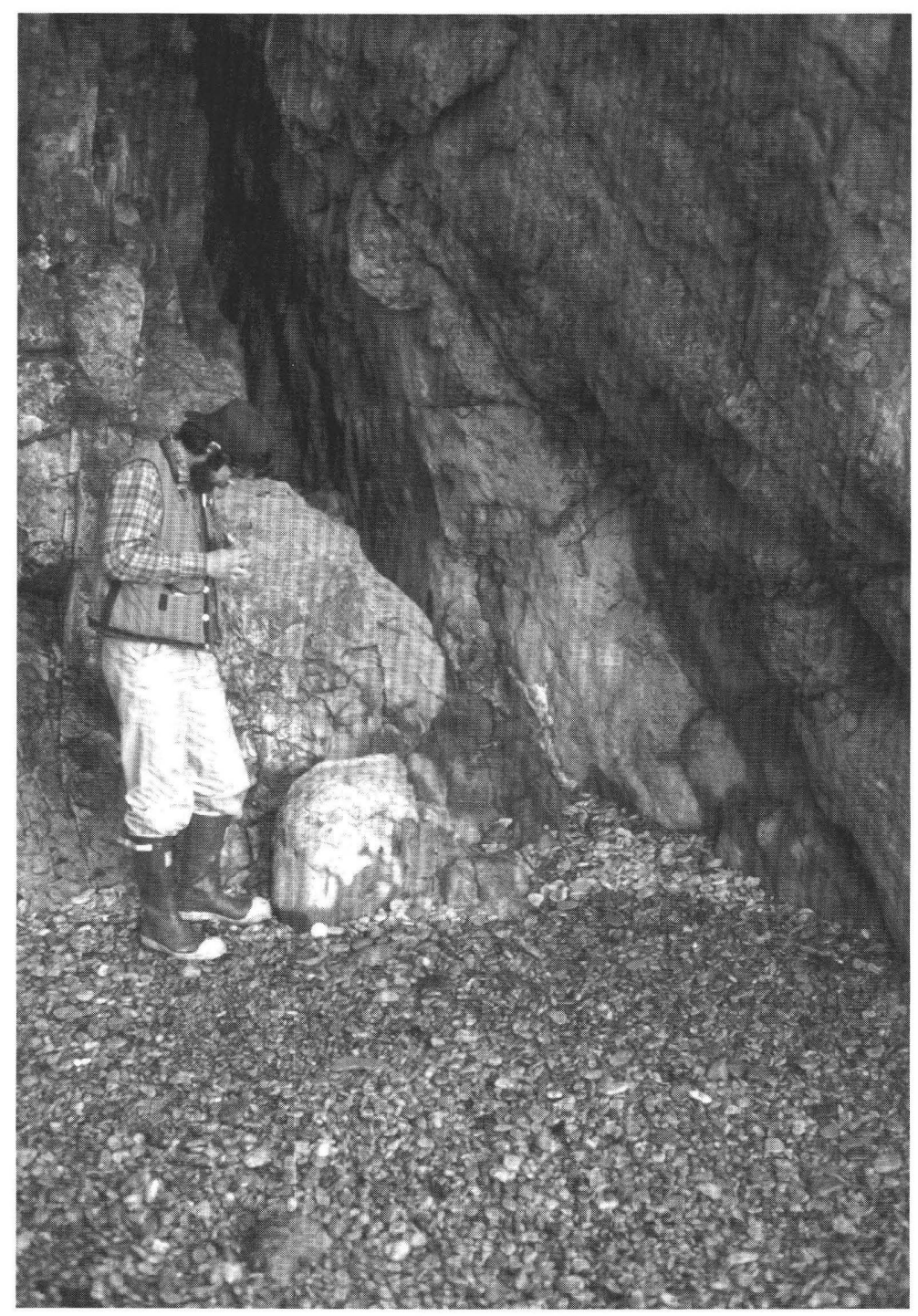

Figure 2. USGS geologist maps an unnamed gold prospect on Mitrofania Island near the Alaska Peninsula in the Stepovak Bay quadrangle of southwestern Alaska. The USGS published the mineral-resource assessment of the Port Moller, Stepovak Bay, and Simeonof Island quadrangles in 1996. Photograph by F. H. Wilson, USGS. 
estimates, mineral extraction and beneficiation methodologies, environmental constraints on mining, and cost analyses for selected major mineral deposits, and the Minerals Industry Location System (MILS), which is a subset of MAS that lists information on the identification and location of each known mineral deposit. Information on the Alaska portions of the MAS and MILS data bases can be obtained from the BLM in Anchorage, Alaska.

\section{BUREAU OF LAND MANAGEMENT}

The BLM manages three classes of mineral resources: leasable minerals, locatable minerals, and salable minerals. Oil, gas, coal, uranium, potash, sodium, and sulfur comprise leasable minerals; placer and lode deposits comprise locatable minerals; and sand, gravel, and building materials comprise salable minerals. The BLM has authority for leasable minerals for all onshore Federal lands in Alaska, including site inspection and enforcement of lease terms. Administration of locatable and salable minerals is restricted to BLM-managed surface estate.

BLM mineral responsibilities include (1) assessment of mineral potential on BLM-managed lands (fig. 1) and, through the planning process, the identification of how the minerals can be optimally managed; (2) development of terms and conditions, through the planning process and environmental review in accordance with the National Environmental Policy Act, for mineral exploration and development on BLM lands; (3) preparation of mineralresource and economic evaluations to determine mineral values for lease sales, land exchanges, and Federal land disposal; (4) administrative maintenance and adjudication of Federal mining claims, determination of claim validity, critical review of all Federal mineral validity reports, and issuance of mineral patents; (5) regulation of mining activities on BLM-managed surface estate to protect the environment, including evaluation of mining Plans and Notices for undue and unnecessary degradation, design and evaluation of mine reclamation criteria, and evaluation of adverse occupancy of mining claims; (6) issuance and management of Federal onshore leases in coordination with the accountable surfacemanagement agency; (7) regulation, permit, and agreement approval, inspection of oil and gas leasehold operations, and enforcement of lease terms for Federal onshore leases producing oil and gas in the Cook Inlet Basin, in compliance with the BLM's National Inspection and Enforcement Strategy; (8) protection of public energy resources through an active program to identify, analyze, and study oil and gas drainage patterns for optimal recovery; (9) determination of resource potential and evaluation of engineering and development scenarios for Federal lands nominated for lease or open to leasing activities by Congressional decree, pursuant to onshore oil and gas leasing orders; (10) administration of lease sales and lease tract analyses of
Federal onshore oil and gas leases; (11) performance of risk assessments for plugged and abandoned wells on Federal lands, in accordance with the State's Abandoned Well Site Closure Program; (12) participation in deyelopment of Alaska Energy InfoBank, a centralized repository for nonproprietary oil and gas data gathered by Federal, State, and industrial entities in Alaska; (13) cooperation with the Alaska Geologic Materials Center to facilitate utilization of geologic samples and analytical data; and (14) assessment of the known oil, gas, and hardrock mineral resources on Federal lands, pursuant to section 1010 of ANILCA.

The BLM is responsible for enforcing the environmental and technical stipulations of the Agreement and Grants of Rights-of-Way for the Trans-Alaska Pipeline System (TAPS). The overall goal of this effort is to ensure continuous oil flow through TAPS by maintaining pipeline integrity and to protect the public and enyironment by minimizing adverse or irreversible impacts. The BLM conducts land-use materials sales to support the operations and maintenance of TAPS. The BLM is also the Authorizing Officer for the Joint Pipeline Office, which audits TAPS monitoring programs and carries out preconstruction activities for proposed pipelines throughout Alaska.

Mineral leasing requires close coordination among Federal surface-management agencies. As in the case of onshore oil and gas leases, the BLM issues leases, maintains reservoir management responsibilities, and integrates its surface inspection and enforcement activities with other land uses in cooperation with the participating agency. To ensure proper surface and subsurface resource protections after a lease is issued, the BLM enforces the regulations in Section 3160 of Title 43, Code of Federal Regulations [43 CFR 3160] and the lease stipulations and permit conditions for exploration and development activities.

\section{MINERALS MANAGEMENT SERVICE}

The primary mission of the MMS in Alaska is the management of mineral-resource exploration and development on Federal Outer Continental Shelf (OCS) lands. Management efforts are largely focused on leasing offshore areas for oil and gas exploration and development, but the MMS also has the authority to lease and manage OCS lands for mining of nonfuel minerals.

Prior to an OCS lease offering, the MMS appraises the economic worth of leasable offshore lands and assesses environmental risks associated with development of resources on or beneath these lands. Following public review and comment, the MMS selectively makes these lands available through competitive OCS lease sales. The MMS regulates postlease exploration, development, and production activities to ensure that operations are conducted in a safe and environmentally acceptable manner. The MMS inspects operations to ensure compliance with applicable laws, 
regulations, and lease terms. Finally, the MMS is responsible for the collection and accounting of rents and royalties generated by the leased properties. Although 80 leases were active at the end of 1996 on the Alaska OCS, no energy or nonfuel-mineral resources were produced; however, development and production plans are underway for the North Star Unit in the Beaufort Sea.

Federal OCS lands begin offshore at 4.8 kilometers, but the OCS Lands Act entitles coastal states to 27 percent of the revenues from leases occurring between 4.8 and 9.7 kilometers offshore from their coasts. During 1996, Alaska's share of such moneys amounted to $\$ 13.28$ million; this included a $\$ 9.38$-million payment from revenues generated by Federal Alaska OCS sales held between 1978 and 1986.

The MMS does not oversee the onshore exploration and development of Federal mineral commodities in Alaska, but the agency is responsible for the collection of royalties, bonus payments, and lease rentals generated from onshore Federal and certain Native lands. Productive leases in the Beaver Creek and Swanson River Oil and Gas Fields, as well as the Beluga and Kenai Gas Fields, provide the bulk of this kind of revenue. The State of Alaska received \$5.07 million as its 1996 share of minerals revenues collected from such properties. Specific data on production and revenues from these fields may be obtained from Michael Baugher, MMS Royalty Management Program, P.O. Box 25165, Denver, CO 80225.

The MMS also conducts regional studies of the geologic history and petroleum potential of Alaska's offshore basins for the National Resource Assessment, an MMS-USGS inventory of America's oil and gas resources. OCS Reports and Maps are geologic studies prepared by MMS professional staff, and OCS Studies are environmental, socioeconomic, and technological investigations that may be prepared on contract. The "Selected References" section of this circular lists some of these titles. Copies of the reports may be obtained from the MMS Public Affairs Office in Anchorage.

\section{NATIONAL PARK SERVICE}

The NPS manages over 206,390 square kilometers in Alaska in 15 administrative units and 13 wild river segments (fig. 3). Under its congressional mandate, the NPS manages all units of the National Park System so as "to conserve the scenery and natural and historic objects and wildlife therein and to provide for the enjoyment of the same in such manner and by such means as will leave them unimpaired for the enjoyment of future generations" [16 USC 1 et seq., NPS Organic Act]. This mandate requires that the NPS manage park ecosystems at the highest possible level of natural resources stewardship. To help the NPS meet that goal, Congress passed the Mining in the Parks Act [16 USC 1901 et seq.] in 1976, closing all park units to the location of new Federal mining claims under the 1872 Mining Law. In 1996, the Federal government purchased the subsurface oil and gas rights to 25 square kilometers in the Yantarni Bay area of Aniakchak National Monument and Preserve.

Minerals management within the NPS deals with a variety of minerals issues including mining claim management, navigability, access, hazardous waste, acquisition, reclamation, and non-Federal oil and gas and other non-Federal minerals. The goal of the NPS is to prevent adverse impacts to park resources from mineral activities occurring on valid claims or private lands within park boundaries owned by individuals, Native corporations, or the State.

The NPS carries out a variety of mineralsmanagement functions through its offices at the national, regional, and park levels. These activities include (1) the evaluation of proposed mining Plans of Operations, including completeness determinations, engineering analysis, impact assessment, and bonding; (2) mineral examinations to determine claim validity; (3) compliance monitoring of approved operations; (4) aerial photography acquisition and topographic mapping; (5) hydrologic monitoring; (6) inventory and cleanup of debris and hazardous materials on abandoned mine lands; and (7) reclamation research and planning. For mining claim acquisition, the NPS conducts mineral and land valuation appraisals, negotiates purchases and donations, and administers relocation of personal property. The NPS also surveys historic and prehistoric sites and provides cultural resources protection for both active and former mining properties.

\section{U.S. FISH AND WILDLIFE SERVICE}

In Alaska, the FWS manages 334,406 square kilometers of National Wildlife Refuge (NWR) surface and submerged lands. This is an increase of 109 square kilometers over 1995 due to the acquisition of inholdings within the Innoko, Kenai, and Kodiak NWR's. Most additions occurred within the Kodiak NWR, where inholdings were purchased using Land and Water Conservation funds and Exxon Valdez Oil Spill Restoration funds; two parcels were donated. An additional 252 square kilometers of subsurface oil and gas rights were purchased in the Yantarni Bay area of the Alaska Peninsula NWR, using congressionally appropriated funds.

Mineral-related activities of the FWS occur both on and off NWR lands and include environmental monitoring, permit review and comment, contaminant analysis, waterresources inventory and assessment, and regulation of certain exploration activities. Some commercial mineral activities may be allowed under permit on national wildlife refuges provided that the activity is compatible with the purposes for which the refuge was established. Under Section 810 of ANILCA, if an activity would significantly restrict subsistence use of Federal lands, the agency must give notice and hold hearings to determine (1) that the restriction is necessary, (2) that a minimum amount of land is affected, and (3) that 


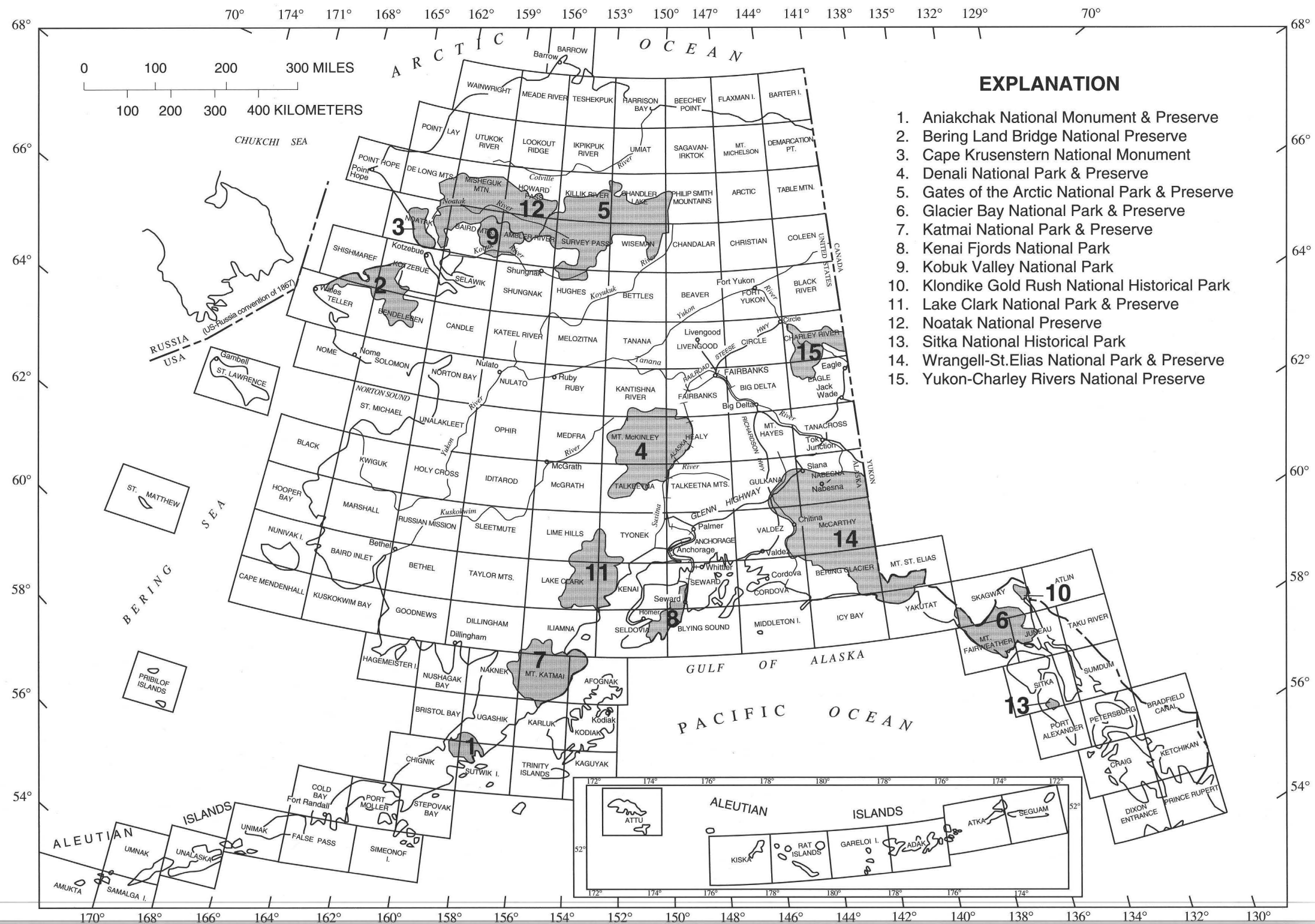

Figure 3. National Park System units in Alaska. 1:250,000-scale quadrangles are outlined and labeled. 
reasonable steps are taken to minimize adverse impacts upon subsistence uses and resources. In 1996, eight special-use permits were issued for minerals activities on Alaska refuges. The locations of the 16 national wildlife refuges in Alaska are shown in figure 4.

The FWS makes recommendations to other Federal agencies for mitigating adverse impacts to fish, wildlife, and habitats from federally constructed, funded, or permitted projects. The FWS also reviews U.S. Army Corps of Engineers (ACE) permit applications under Section 404 of the Clean Water Act of 1977, as amended, and under Section 10 of the Rivers and Harbors Act of 1899, as amended; these permit requirements apply to both public and private lands and waters. In 1996, the FWS reviewed 84 Section 404 applications for oil, gas, and mining activities.

The FWS manages migratory birds, species listed as threatened and endangered, and certain marine mammals. When an agency is considering permit applications for exploration or development activity, that agency must determine if listed species are present within the area of activity. When a listed species is present and it is determined that the proposed activity may adversely affect that species, the agency must consult with the FWS in accordance with the Endangered Species Act of 1973, as amended.

The FWS manages three marine mammal species in Alaska: polar bear, sea otter, and Pacific walrus. Section 101(a)(5) of the Marine Mammal Protection Act of 1972, as amended, authorizes the Secretary of the Interior to allow, via a Letter of Authorization (LOA), the incidental, but not intentional, taking of small numbers of marine mammals when engaged in a specified activity in a specified region; these LOA's are restricted to U.S. citizens. Nine LOA's were issued in 1996 in conjunction with oil and gas industry activities in the Beaufort Sea and adjacent coastal Alaska.

\section{U.S. DEPARTMENT OF ENERGY}

The DOE administers Congressional mandates relating to energy, monitors grants, and oversees contracts for energy-resource studies. In Alaska, the DOE is focusing its efforts on petroleum, natural gas, and coal resources.

To develop a better understanding of petroleum resources and to provide fundamental information to accelerate utilization of these resources, the DOE emphasizes resource and technological investigations that continue to expand the body of essential and basic scientific knowledge concerning conventional and heavy petroleums. A 4-year cooperative research and development agreement was negotiated in 1995 with BP Exploration to investigate the economic recovery of heavy oil from the Prudhoe Bay Oil Field on Alaska's North Slope.

The DOE works to evaluate Alaskan coal in terms of its potential contribution to total national resources. Coal research currently centers on utilization methods suitable to Alaskan coals and conditions. Recent interest in coalbedmethane resources in Alaska may allow for remote power generation using this indigenous energy source. The DOE's Clean Coal Technology Program is funding two projects in Alaska: the Healy Clean Coal Project, under construction in central Alaska, will demonstrate new, clean-burning technology that limits the emission of pollutants commonly cited as a cause of acid rain; and the Coal-Diesel Project, currently in the permitting stage, will demonstrate an advanced coal-fueled diesel engine to generate electricity at the University of Alaska-Fairbanks.

\section{U.S. DEPARTMENT OF AGRICULTURE}

\section{FOREST SERVICE}

The FS cooperates with DOI agencies in issuing mineral leases and assuring mitigation of surface impacts from lease activities. Under a Memorandum of Understanding with the BLM, the FS jointly administers the general mining laws on National Forest System (NFS) lands in Alaska. As part of the process, the FS conducts field examinations for mineral patent applications and mining claim validity determinations; the resultant mineral reports are submitted to the BLM for review and adjudication.

The FS also cooperates with State agencies and the private sector in the development of energy and mineral resources on inholdings. One such inholding is the Bering River Coal Field in Chugach National Forest, which is under consideration for possible development in a joint venture by Chugach Alaska Corporation and others.

In Alaska, 93,000 square kilometers of land in 14 ranger districts (fig. 5) is administered by the FS through its regional office in Juneau. The Chugach National Forest is located in south-central Alaska and has offices in Anchorage, Cordova, Girdwood, and Seward; the Tongass National Forest is in southeastern Alaska and has offices in Craig, Hoonah, Juneau, Ketchikan, Petersburg, Sitka, Thorne Bay, Wrangell, and Yakutat. 


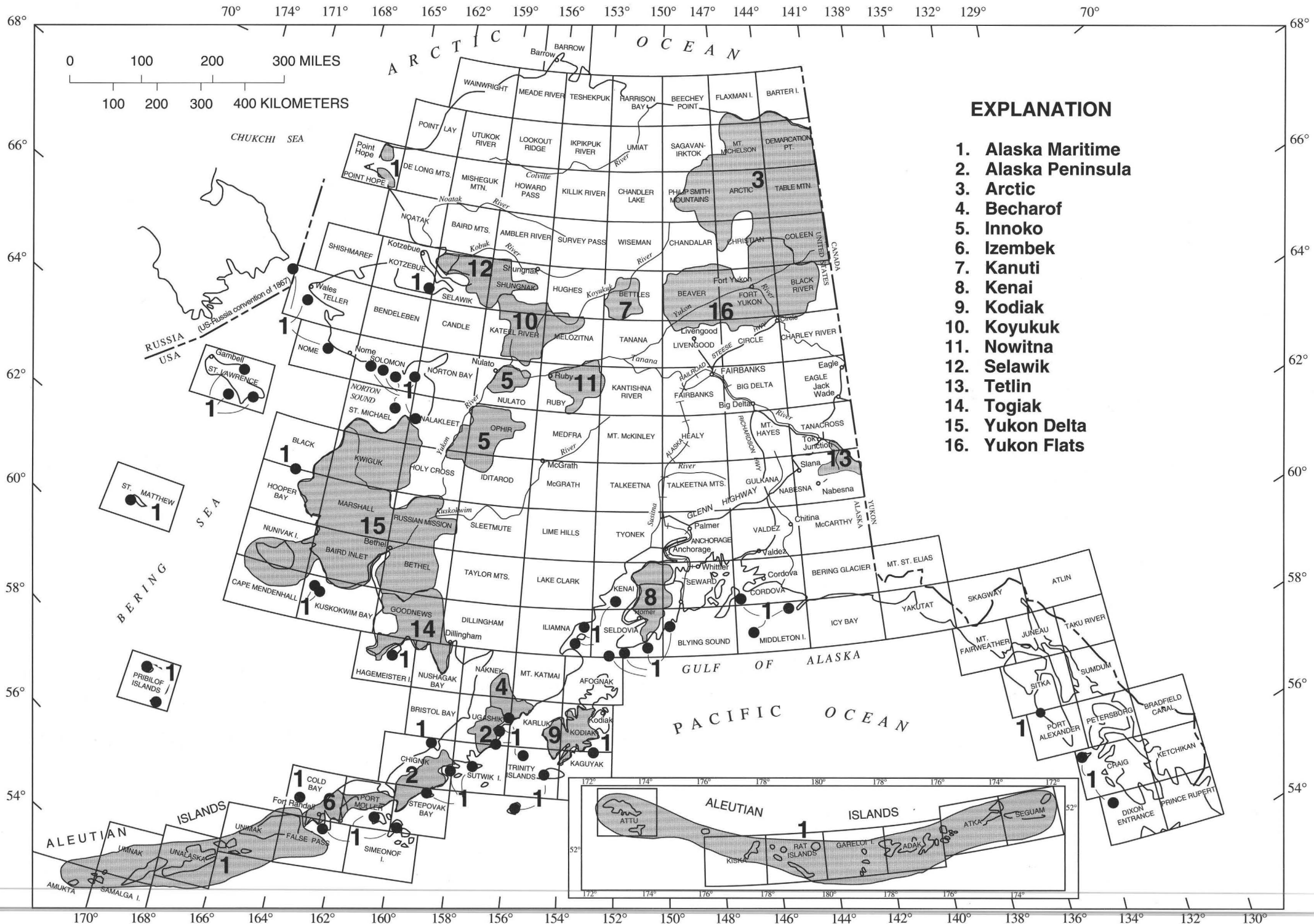

Figure 4. National wildlife refuges in Alaska. 1:250,000-scale quadrangles are outlined and labeled. 


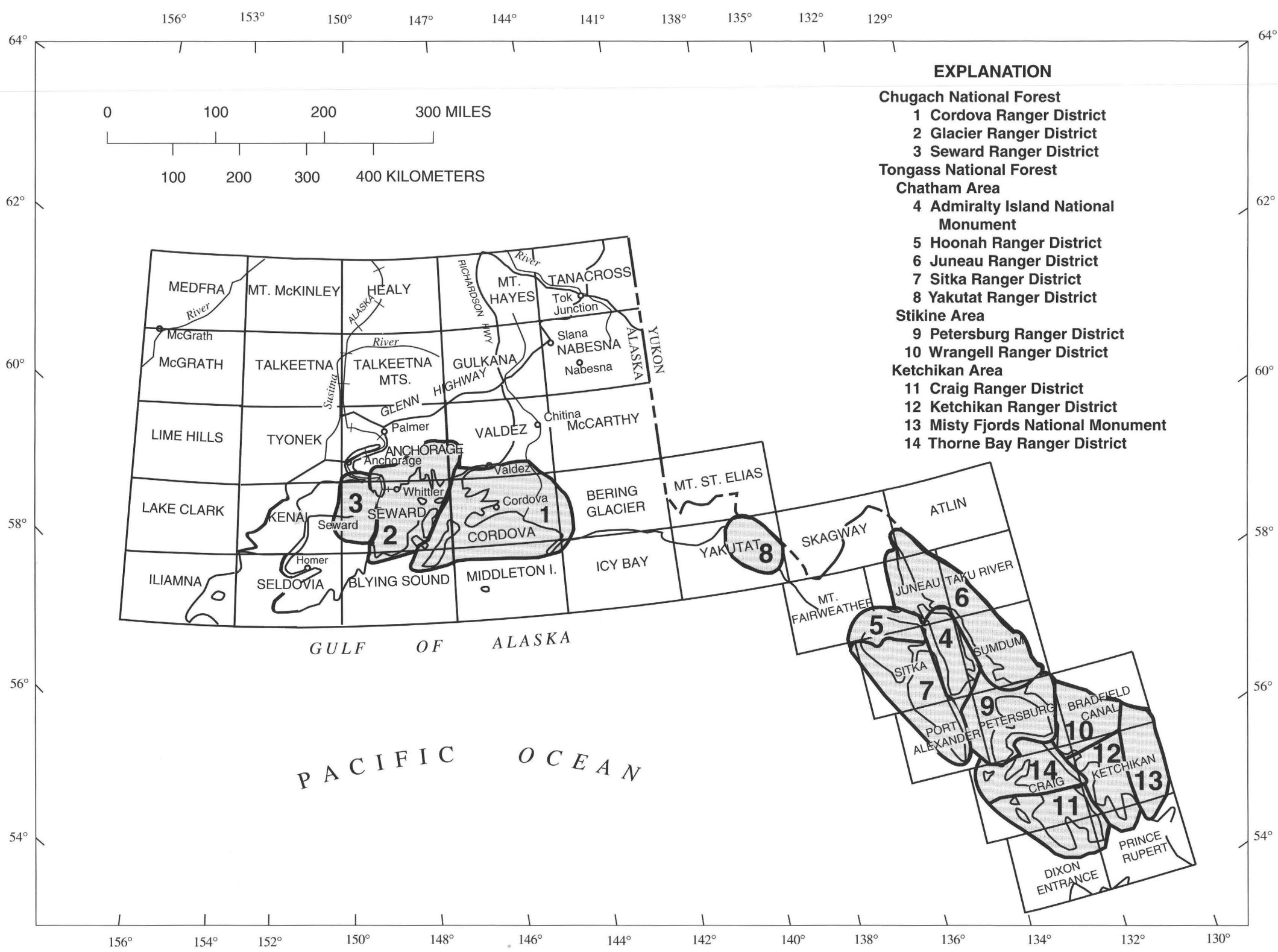

Figure 5. Forest Service ranger districts in Alaska. 1:250,000-scale quadrangles are outlined and labeled. 


\section{CONTACTS FOR FURTHER INFORMATION}

\section{U.S. DEPARTMENT OF THE INTERIOR}

Bureau of Land Management

Tom Allen, State Director

Federal Building

222 West Seventh Avenue, No. 13

Anchorage, AK 99513-7599

Minerals Management Service

John T. Goll, Regional Director

Alaska OCS Region

University Plaza Building

949 East 36th Avenue

Anchorage, AK 99508-4363

National Park Service

Robert Barbee, Field Director

Alaska Field Office

2525 Gambell Street, Room 107

Anchorage, AK 99503-2892

U.S. Fish and Wildlife Service

David B. Allen, Regional Director

1011 East Tudor Road

Anchorage, AK 99503-6199

U.S. Geological Survey

Alison B. Till, Associate Chief Scientist

Mineral Resources Survey Program-Western

Region

4200 University Drive

Anchorage, AK 99508-4667

\section{U.S. DEPARTMENT OF ENERGY}

Hydrocarbon Resources

Charles Byrer

Federal Energy Technology Center

P.O. Box 880, 3610 Collins Ferry Road

Morgantown, WV 26507-0880

Forest Service

Regional Forester

Alaska Region

P.O. Box 21628

Juneau, AK 99802-1628 


\section{- ENERGY RESOURCES-}

\section{OIL AND GAS RESOURCES}

\section{OVERVIEW OF PRODUCTION AND PRICES}

Oil and gas remained the most valuable commodities produced in Alaska. Alaska's two oilproducing areas, the Arctic North Slope and the Cook Inlet region, provided a total of 510.8 million barrels $(1$ barrel $=$ 159 liters) of oil, 33.2 million barrels of natural gas liquids (NGL), 5.23 billion cubic meters of dry natural gas, and 90.8 billion cubic meters of casinghead gas in 1996 (table 1); 83 billion cubic meters of gas and 962 million barrels of water were reinjected for enhanced oil recovery. Oil and NGL production decreased by 4.8 percent from 1995 levels; dry gas production increased 2 percent. Daily oil production averaged 1.4 million barrels per day (bbl/d), almost 85,000 $\mathrm{bbl} / \mathrm{d}$ less than in 1995.

Alaska's oil production has fallen steadily since the peak year of 1988 (table 2), when 738.6 million barrels was produced. As the oil reservoirs have been drawn down, proportionately more casinghead gas and water have been produced as by-products; this gas and water are separated from the crude oil and reinjected in the field to enhance oil recovery. Annual production of NGL has also increased over the years to 33 million barrels in 1996. Despite decreasing production, Alaska provided about 25 percent of total United States oil production in 1996, and among the 50 states, ranked tenth in revenues from Federal oil and gas leases.

Alaska North Slope crude oil prices in 1996 were lowest at the first of the year, rose to a peak in May, declined slightly, then rose to a high for the year in November (fig. 6). The average 1996 price was $\$ 19.86$ per barrel, 18 percent above the 1995 average price of $\$ 16.81$ and the highest since 1990 (fig. 7). In previous years, BP Exploration Alaska (BPX-Ak) had listed prices for both West Coast and Gulf Coast deliveries but discontinued this two-tier pricing structure in 1996. Alaska's treasury is especially vulnerable to crude oil prices because 80 percent of its current revenues are derived from royalties and taxes paid on State-owned oil and gas leases.

A Federal law that lifted the 23-year ban on exports of North Slope oil was passed in late 1995, and regulations were issued in 1996 to address the environmental and safety issues involved. BPX-Ak signed a 1-year contract to export $10,000 \mathrm{bbl} / \mathrm{d}$, or four tanker loads, to a petroleum company in Taiwan.

The oil and gas industry, in cooperation with Federal and State agencies, created the Alaska Energy InfoBank in 1995, a centralized repository for all

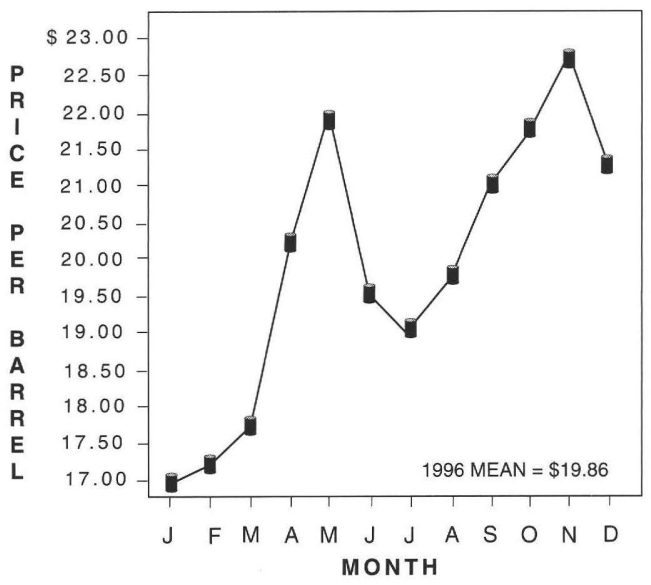

Figure 6. Fluctuation in Alaska North Slope crude oil prices for 1996. Data compiled from Alaska Report.

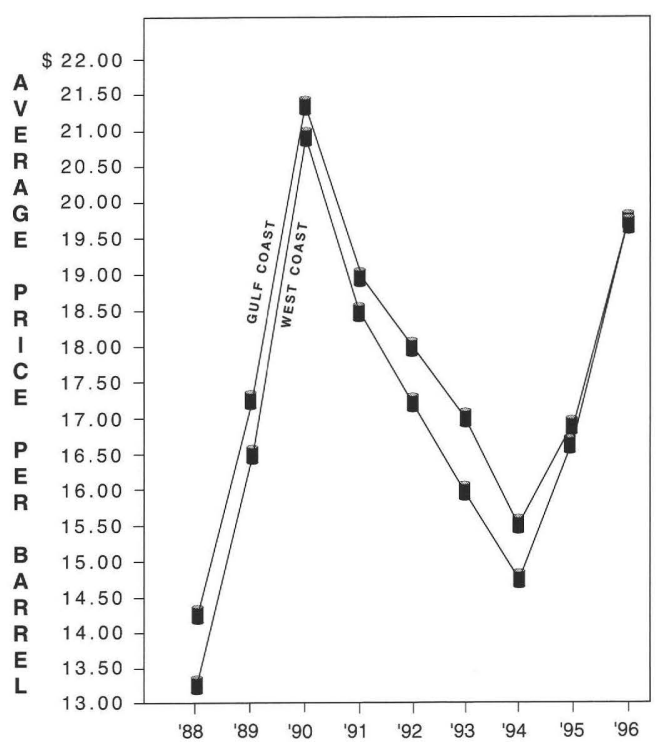

Figure 7. Fluctuation in annual average price of Alaska North Slope crude oil, 1988-1996. Averages calculated from data compiled from Alaska Report. 
Table 1. 1996 Alaskan oil and gas production statistics.

[Data from Alaska Oil and Gas Conservation Commission (1997); fields listed in descending order of production of oil or dry natural gas. BBL, barrels; NGL, natural gas liquids; MCM, thousand cubic meters; DNG, dry natural gas; CHG, casinghead gas; _ _ no production]

\begin{tabular}{|c|c|c|c|c|}
\hline FIELD & BBL OIL & BBL NGL & MCM DNG & MCM CHG \\
\hline \multicolumn{5}{|l|}{ NORTH SLOPE } \\
\hline PRUDHOE BAY & $298,061,969$ & $31,358,842$ & - & $80,125,453$ \\
\hline KUPARUK RIVER & $99,459,400$ & - & - & $3,052,706$ \\
\hline POINT MCINTYRE & $57,926,190$ & 824,633 & - & $1,602,288$ \\
\hline ENDICOTT & $26,648,881$ & $1,013,850$ & 951 & $3,512,218$ \\
\hline MILNE POINT & $14,100,385$ & - & - & 194,924 \\
\hline WALAKPA & - & - & 32,859 & - \\
\hline EAST BARROW & - & - & 1,822 & - \\
\hline SOUTH BARROW & - & - & 1,452 & - \\
\hline SUBTOTALS & $496,196,825$ & $33,197,325$ & 37,084 & $88,487,589$ \\
\hline \multicolumn{5}{|l|}{ COOK INLET } \\
\hline MCARTHUR RIVER & $6,102,208$ & - & $1,798,450$ & 106,558 \\
\hline GRANITE POINT & $2,556,020$ & - & 3,684 & 60,063 \\
\hline MIDDLE GROUND SHOAL & $2,396,458$ & - & 177 & 23,963 \\
\hline SWANSON RIVER & $1,521,462$ & 18,885 & 35,369 & $2,121,206$ \\
\hline WEST MCARTHUR RIVER & $1,295,740$ & - & - & 8,760 \\
\hline TRADING BAY & 589,506 & - & 629 & 10,271 \\
\hline BEAVER CREEK & 124,887 & - & 85,164 & 963 \\
\hline NORTH COOK INLET & - & - & $1,585,055$ & - \\
\hline BELUGA RIVER & - & - & $1,045,730$ & - \\
\hline KENAI & - & 15 & 435,125 & - \\
\hline IVAN RIVER & - & - & 187,040 & - \\
\hline PRETTY CREEK & - & - & 8,531 & - \\
\hline STUMP LAKE & - & - & 5,244 & - \\
\hline LEWIS RIVER & - & - & 3,237 & - \\
\hline STERLING & - & - & 1,034 & - \\
\hline SUBTOTALS & $14,586,281$ & 18,900 & $5, \overline{194,469}$ & $2,331,784$ \\
\hline TOTALS & $510,783,106$ & $33,216,225$ & $5,231,553$ & $90,819,373$ \\
\hline
\end{tabular}

Table 2. Oil and gas production in Alaska, 1902-1996.

[Data from Alaska Oil and Gas Conservation Commission (1997); BBL, barrels; NGL, natural gas liquids; MCM, thousand cubic meters; DNG, dry natural gas; $\mathrm{CHG}$, casinghead gas]

\begin{tabular}{rrrrr}
\hline YEAR & BBL OIL & BBL NGL & MCM DNG & MCM CHG \\
\hline pre-1988 & $7,002,944,103$ & $30,650,300$ & $89,132,814$ & $294,106,662$ \\
& & & & \\
1988 & $738,555,472$ & $21,224,309$ & $5,291,778$ & $49,982,322$ \\
1989 & $684,624,534$ & $18,888,342$ & $5,530,919$ & $50,392,896$ \\
1990 & $647,513,924$ & $18,190,587$ & $5,810,827$ & $52,663,363$ \\
1991 & $656,388,109$ & $23,883,790$ & $5,623,176$ & $62,110,192$ \\
1992 & $627,341,337$ & $26,864,398$ & $5,669,758$ & $69,092,075$ \\
1993 & $577,946,276$ & $26,847,508$ & $5,413,541$ & $73,713,558$ \\
1994 & $568,967,418$ & $25,890,655$ & $5,143,155$ & $82,717,616$ \\
1995 & $541,653,315$ & $29,649,356$ & $5,109,784$ & $90,835,783$ \\
1996 & $510,783,106$ & $33,216,225$ & $5,231,553$ & $90,819,373$ \\
SUBTOTALS & $5,553,773,491$ & $224,655,170$ & $48,824,491$ & $622,327,178$ \\
TOTALS & $\mathbf{1 2 , 5 5 6 , 7 1 7 , 5 9 4}$ & $\mathbf{2 5 5 , 3 0 5 , 4 7 0}$ & $\mathbf{1 3 7 , 9 5 7 , 3 0 5}$ & $\mathbf{9 1 6 , 4 3 3 , 8 4 0}$ \\
\hline
\end{tabular}


nonproprietary oil and gas data shared by those entities. In addition to geologic information from well logs and seismic lines, the database includes production data and mandated regulatory materials such as permits and environmental assessments. The Energy InfoBank promotes standards for data storage, facilitates data retrieval, and minimizes storage costs for duplicate copies of permits, reports, and assessments. Projected savings were estimated at \$7 million annually. ARCO Alaska (ARCO-Ak), BPX-Ak, Exxon, Marathon, Unocal, Alyeska Pipeline Service Company, Alaska Department of Natural Resources (ADNR), Alaska Oil and Gas Conservation Commission (AOGCC), the BLM, and the MMS are current participants in the InfoBank.

\section{LEASING ACTIVITY}

The MMS conducted its first OCS lease sale in Alaska since 1991 (Minerals Management Service, 1995a 1996b). On September 18, OCS Sale 144 offered 1,413 tracts covering 29,540 square kilometers in the Beaufort Sea planning area. Five companies submitted 31 bids in the sale, and 29 leases covering 405 square kilometers were awarded for a total of $\$ 14,429,363$. The highest bid received, submitted by BPX-Ak, was \$10,611,680 for a four-block tract near the Tern Island exploration area. Other winning bidders included ARCO-Ak, Anadarko Petroleum, Chevron U.S.A., and Petrofina Delaware.

The State of Alaska also held a lease sale in northern Alaska. Held in October, State Sale 86A offered 13 tracts covering 63 square kilometers on the Colville River delta adjacent to the eastern edge of the National Petroleum Reserve-Alaska (NPRA). Some of the acreage offered is jointly owned by the State and the Arctic Slope Regional Corporation. Five tracts were leased for \$2 million. All winning bids were made by a consortium composed of ARCO-Ak, Anadarko Petroleum, and Union Texas.

The State held its second lease sale of 1996 in southcentral Alaska. State Sale $85 \mathrm{~A}$ was held in December and offered 234 tracts in the Cook Inlet region. Total high bids brought \$3.1 million for 44 tracts covering 702 square kilometers. Successful bidders included ARCO-Ak, Anadarko Petroleum, Forcenergy, Marathon Oil, Union Texas, Unocal, and several other small companies and investor groups.

\section{EXPLORATION}

Permits.-The AOGCC issued 203 drilling permits in 1996, a 6-percent decrease from 1995 (Alaska Oil and Gas Conservation Commission, 1997). Fourteen exploratory wells were permitted, 12 on the North Slope and 2 in the Cook Inlet region, but not all the wells were drilled by year's end. Also permitted were 168 development wells and 21 service wells.
Geophysical surveys.-Seismic surveys were conducted in Cook Inlet and on the North Slope. More than 1,127 line-kilometers of two-dimensional surveys were permitted for Cook Inlet. On the North Slope, more than 3,212 square kilometers of three-dimensional surveys and 644 line-kilometers of two-dimensional surveys were conducted in numerous areas, both onshore and offshore.

Drilling.-Twelve exploratory wells were active in 1996, three more than the year before: ten wells were active on the North Slope and two in the Cook Inlet region (fig. 8; table 3). Although most wells were plugged and abandoned, complete information on the wells has not been released.

Alpine discovery.-ARCO-Ak and partners Union Texas and Anadarko Petroleum announced the Alpine Oil Field discovery in the Colville River delta on the North Slope. Containing 250-300 million barrels of recoverable oil, Alpine is the largest field discovered in Alaska since the Point McIntyre discovery in 1988. The Alpine field covers 162 square kilometers and will be developed from two gravel pads. Production is anticipated to start by 2000 and reach peak production within a year at about 60,000 bbld. A 55kilometer pipeline will transport the oil to the Kuparuk field and TAPS. The discovery is adjacent to NPRA and to lands offered in State Sale 86A, in which the Alpine partners were the successful bidders.

\section{DEVELOPMENT}

North Slope.-Although BPX-Ak submitted a revised plan of development for the Badami field to the Alaska Division of Oil and Gas, a formal decision had not yet been made to develop the field, which is estimated to contain as much as 100 million barrels of oil and 2.8 billion cubic meters of gas. Results from recently drilled wells showed that the reservoir was more complex than previously believed. The Badami field is located about 60 kilometers east of the Endicott field.

Beaufort Sea.-BPX-Ak planned to develop the Northstar field, which lies 13 kilometers north of Milne Point and north of the offshore barrier islands. The field was discovered in 1982 and is estimated to contain between 100 and 200 million barrels of recoverable oil. Because the field is under 9 to 12 meters of water, technical issues include reinforcement of the man-made Seal Island, location of proposed production facilities, and design of a 10-kilometerlong undersea pipeline. BPX-Ak has begun work on an Environmental Impact Statement (EIS).

\section{PRODUCTION}

At the end of 1996, there were 1,756 producing oil wells, 102 gas wells, 705 service wells, and 27 disposal wells active in Alaska (Alaska Oil and Gas Conservation 


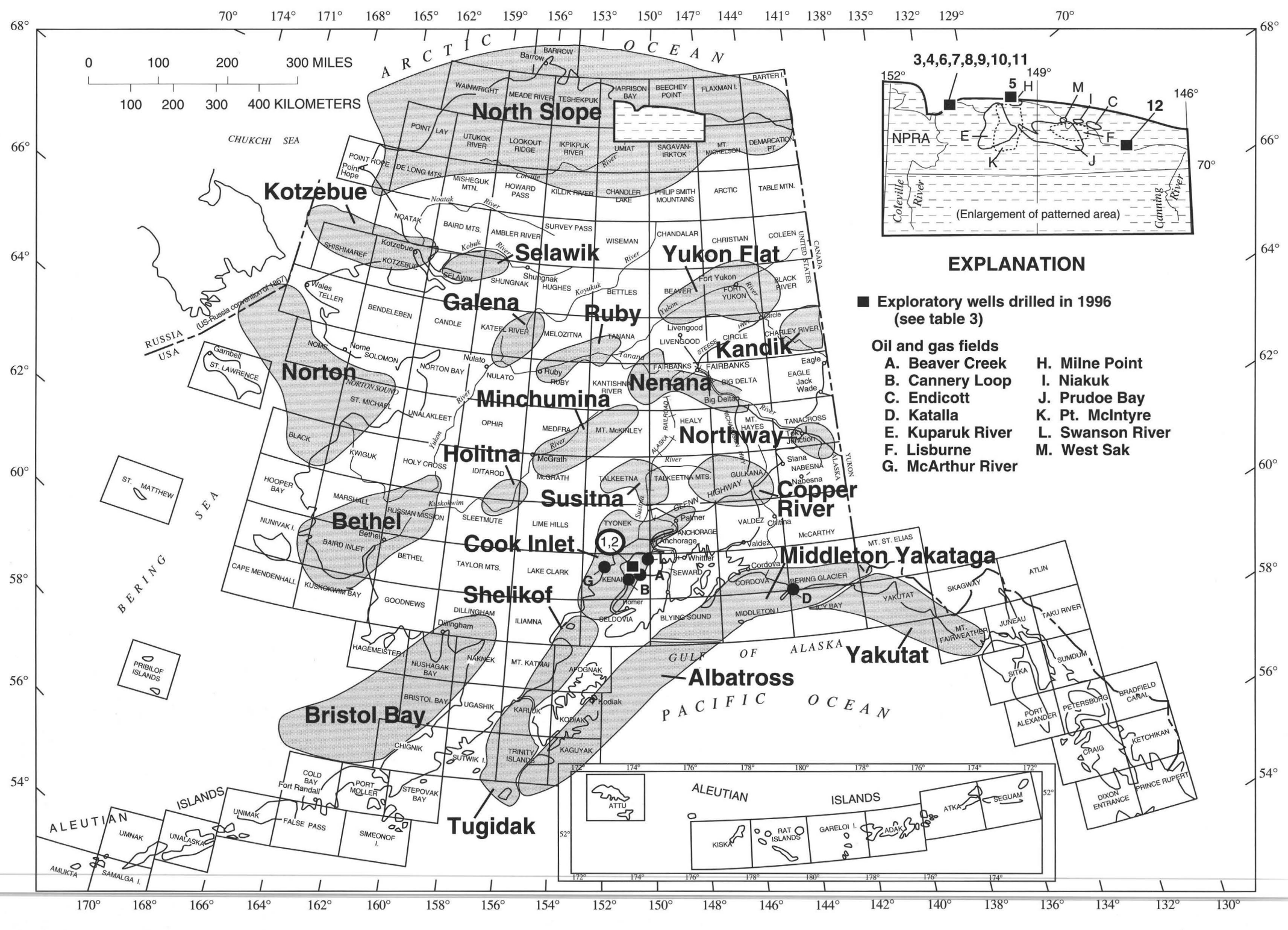

Figure 8. Locations of 1996 exploratory oil wells, known oil and gas fields, and possible petroleum-bearing sedimentary basins (shaded). Basins adapted from Kirschner (1988). 1:250,000-scale quadrangles are outlined and labeled. 
Table 3. Alaska exploratory oil wells drilled on Federal and State lands in 1996.

[Data from Alaska Oil and Gas Conservation Commission (1997); see figure 8 for locations. Cook Inlet wells were drilled on Federal lands, North Slope wells were drilled on State lands. Locations given in section-township-range; SM, Seward Meridian (Cook Inlet); UM, Umiat Meridian (North Slope). ARCO-Ak, ARCO Alaska; BPX-Ak, BP Exploration-Alaska, P\&A, plugged and abandoned]

\begin{tabular}{lllll}
\hline Well Company & Well name & API Number & Location & $\begin{array}{l}\text { Total } \\
\text { depth } \\
\text { (meters) }\end{array}$ \\
& & $\begin{array}{l}\text { Date } \\
\text { completed }\end{array}$ & Remarks \\
\hline
\end{tabular}

Cook Inlet (Federal)

\begin{tabular}{|c|c|c|c|c|c|c|c|}
\hline $\begin{array}{l}1 . \\
2 .\end{array}$ & $\begin{array}{l}\text { ARCO-Ak } \\
\text { Marathon }\end{array}$ & $\begin{array}{l}\text { Bufflehead } 1 \\
\text { Corea Creek Fed } 1\end{array}$ & $\begin{array}{l}50-133-20466-00 \\
50-133-20467-00\end{array}$ & $\begin{array}{l}03-08 \mathrm{~N}-09 \mathrm{~W}, \mathrm{SM} \\
12-01 \mathrm{~N}-13 \mathrm{~W}, \mathrm{SM}\end{array}$ & $\begin{array}{l}3,674 \\
2,968\end{array}$ & $5 / 31$ & $\begin{array}{l}\text { suspended } \\
\text { gas production }\end{array}$ \\
\hline \multicolumn{8}{|c|}{ North Slope (State) } \\
\hline 3. & ARCO-Ak & Bergschrund 2 & 50-103-20232-00 & 09-11N-05E,UM & 2,621 & $2 / 27$ & $\mathrm{P} \& \mathrm{~A}$ \\
\hline 4. & ARCO-Ak & Alpine 3 & 50-103-20234-00 & 25-12N-04E,UM & 2,331 & $3 / 11$ & P\&A \\
\hline 5. & BPX-Ak & North Milne Point 2 & 50-029-22653-00 & 17-14N-10E,UM & 4,595 & $3 / 18$ & P\&A \\
\hline 6. & ARCO-Ak & Alpine 1B & 50-103-20211-02 & 01-11N-04E,UM & 2,697 & $3 / 23$ & $\mathrm{P} \& \mathrm{~A}$ \\
\hline 7. & ARCO-AK & Nanuk 1 & 50-103-20238-00 & 19-11N-05E,UM & 2,326 & $3 / 24$ & P\&A \\
\hline 8. & ARCO-Ak & Temptation 1 & 50-103-20233-00 & 16-12N-04E,UM & 2,362 & $4 / 04$ & P\&A \\
\hline 9. & ARCO-Ak & Bergschrund 2A & 50-103-20232-01 & 09-11N-05E,UM & 2,407 & & suspended \\
\hline 10. & ARCO-Ak & Neve 1 & 50-103-20231-00 & 14-11N-04E,UM & 2,347 & $4 / 23$ & $\mathrm{P} \& \mathrm{~A}$ \\
\hline 11. & ARCO-Ak & Temptation 1A & 50-103-20233-01 & 16-12N-04E,UM & 2,728 & $4 / 23$ & $\mathrm{P} \& \mathrm{~A}$ \\
\hline 12. & BPX-Ak & Sourdough 3 & 50-089-20026-00 & 29-09N-24E,UM & 3,790 & & suspended \\
\hline
\end{tabular}

Commission Bulletin, February 1997). Of these, 140 development and 18 service wells were drilled in 1996. Some data on these wells have been made available through AOGCC monthly bulletins and annual report and the Petroleum Information Corporation's weekly Alaska Report. North Slope fields produced 97 percent of Alaska's oil and NGL during 1996, and the Cook Inlet region produced 99 percent of the State's dry natural gas.

\section{NORTH SLOPE}

Prudhoe Bay.-The Prudhoe Bay field, the Nation's largest producing oil field, generated 329.4 million barrels of oil and natural gas liquids, about 62 percent of North Slope production; this was a 7-percent decline from 1995 totals. By year's end, the field had produced a cumulative total of 9.4 billion barrels of oil. When discovered in 1968 , the field was estimated to contain 9.6 billion barrels of recoverable oil, but producers are now confident that they will be able to recover 13 billion barrels. One factor is the 25-percent cost reduction, since 1991, for a North Slope well, which has allowed more development wells to be drilled than initially anticipated. Another factor is development of the horizontal drilling technique, which has allowed more effective access to remaining reserves in the field.
The Niakuk pool of the Prudhoe Bay field was discovered in 1985 and began production in 1994. Oil production during 1996 totaled 10.9 million barrels, a 55-percent increase from 1995. Estimated to contain 54 million barrels of recoverable oil, Niakuk is located entirely offshore in the eastern part of Prudhoe Bay and is being developed through extended-reach drilling from an onshore production facility at Heald Point. The Niakuk NK-28 (West Niakuk 2) well, which was drilled in 1996 to test the western limit of the field, is notable for two reasons: the hole's total depth of 6.5 kilometers set the North Slope record for extended-reach drilling, and the well also produces about 4,500 bbl/d of oil.

Kuparuk River-The Kuparuk River field is the Nation's second largest producing oil field, generating $272,492 \mathrm{bbl} / \mathrm{d}$ of oil in 1996 . An enhanced oil-recovery project was initiated in 1996: additional development wells were to be drilled, and gas injection expanded from the current 5 drill sites to 15 drill sites. A solvent used in the reinjection and recovery process will be manufactured on-site, using 25,000 bbl/d of NGL from Prudhoe Bay. The goal of the project is to increase and maintain the level of production to $300,000 \mathrm{bbl} / \mathrm{d}$ over the next 5 years, ultimately recovering an additional 200 million barrels of oil.

Milne Point.-Output at the Milne Point Oil Field 
in 1996 was $38,631 \mathrm{bbl} / \mathrm{d}$, up 62 percent from $23,811 \mathrm{bbl} / \mathrm{d}$ in 1995. New development wells throughout the field, production from the offshore extension of the Kuparuk reservoir, and production from the onshore Cascade pool all contributed to the increased yield. Continued expansion of production facilities is expected to increase output to 60,000 $\mathrm{bbl} / \mathrm{d}$. BPX-Ak originally estimated recovering 100 million barrels of oil from the Milne Point field, but now anticipates recovery of more than 300 million barrels.

The Cascade pool, which lies 5 kilometers southeast of the main part of the field, was discovered in 1993, and 1996 was its first year of production. Cascade contains at least 20 million barrels of recoverable oil and is expected to produce $15,000 \mathrm{bbl} / \mathrm{d}$.

\section{COOK INLET}

In 1996, the Cook Inlet region produced 14.6 million barrels of oil and NGL, a 6-percent decrease from 1995, and 5.2 billion cubic meters of dry natural gas, a 2-percent increase. Fifteen fields were active, one less than the previous year; the West Fork Gas Field did not produce in 1996. The top five oil fields produced 95 percent of the region's total, and the top five gas producers yielded 97 percent of the region's dry natural gas. The McArthur River field alone produced 42 percent of the oil and 35 percent of the gas for the region. West McArthur River was the only field to increase oil production, from 2,526 bbl/d in 1995 to 3,550 $\mathrm{bbl} / \mathrm{d}$ in 1996; West McArthur River is the newest field in the region and has not yet reached peak production.

Access to abundant natural gas was a primary factor in Alyeska Alloys' selection of Tyonek as the site for its planned iron carbide production facility, which will use Cook Inlet gas to produce iron carbide from iron ore imported from South America; the finished product is to be shipped to Pacific Rim sites for use in steel production. The two-module iron reduction plant will utilize 269 million cubic meters of gas and 1 million metric tons of iron ore to produce 700,000 metric tons of iron carbide annually. The company applied to the Alaska Industrial Development and Export Authority (AIDEA) for funding to extend the existing Native-owned dock at Tyonek into deeper water for a planned shipping facility. If funding is approved, construction of the plant could begin by spring of 1999 . The plant would be the second one of its type built in the United States and only the third one worldwide.

\section{TRANSPORTATION}

Trans-Alaska oil pipeline.-TAPS is 1,280 kilometers long, connecting the oil fields of Alaska's North Slope to port facilities at Valdez. More than 10.5 billion barrels of oil have been transported through TAPS since its startup in 1977, but declining production from North Slope fields has dropped daily throughput from a peak of 2 million barrels in 1988 to less than 1.5 million barrels in 1996. Because less power is needed to move less oil through the pipeline, 3 of the line's 12 pump stations were shut down in 1996 as a cost-cutting measure. State officials estimated that current and newly discovered oil fields should provide sufficient throughput to keep TAPS in operation through 2017.

Alpine development pipeline.-A 55-kilometer-long oil pipeline has been designed to connect ARCO-Ak's Alpine field to the production facilities at the Kuparuk River field; the pipeline would be 0.6 meters in diameter. Peak production from Alpine has been forecast at $60,000 \mathrm{bbl} / \mathrm{d}$, and production may begin as soon as 2000. An application for pipeline rightof-way was processed by the Federal-State Joint Pipeline Office (JPO) in 1996.

Proposed natural gas pipeline.-Yukon Pacific Corporation has proposed construction of a 1,280-kilometerlong natural gas pipeline that will parallel TAPS. Starting at Prudhoe Bay and ending at a liquefied-natural-gas plant at Anderson Bay near Valdez, the pipeline would provide access to approximately 850 billion cubic meters of known North Slope natural gas reserves. Estimated cost of this pipeline is $\$ 18.4$ billion. Yukon Pacific has received all major government approvals for this project, and the Federal Energy Regulatory Commission has approved construction and operation of the liquefaction plant. Two factors have delayed construction of the pipeline: North Slope natural gas is currently reinjected to maximize oil recovery, and, at present, there is no market for the gas. Major North Slope gas owners contend the project is too costly to be profitable.

\section{ACTIVITY BY FEDERAL AGENCIES}

\section{MINERALS MANAGEMENT SERVICE}

LEASING AND EXPLORATION ACTIVITY

In September 1996, the MMS conducted OCS Lease Sale 144 in the Beaufort Sea planning area (Minerals Management Service, 1995a), the first sale in Alaska since 1991 (fig. 9). High bids totaling $\$ 14,429,363$ were accepted on 29 tracts covering 405 square kilometers. BPX-Ak submitted the highest single bid, paying \$10.6 million for a four-block tract near Tern Island.

Lease Sale 144 was the eighteenth OCS sale that the DOI has held in Alaska (fig. 8, table 4). Beginning in 1976, the DOI has offered oil and gas leases in 8 of the 15 Alaska OCS planning areas and has awarded 1,591 leases covering 35,165 square kilometers, receiving almost $\$ 6.5$ billion in high bonus bids. A total of 1,511 leases have been relinquished or have expired, leaving 80 leases still held by oil and gas companies as of December 31, 1996 (table 5).

Fourteen continental offshore stratigraphic test 


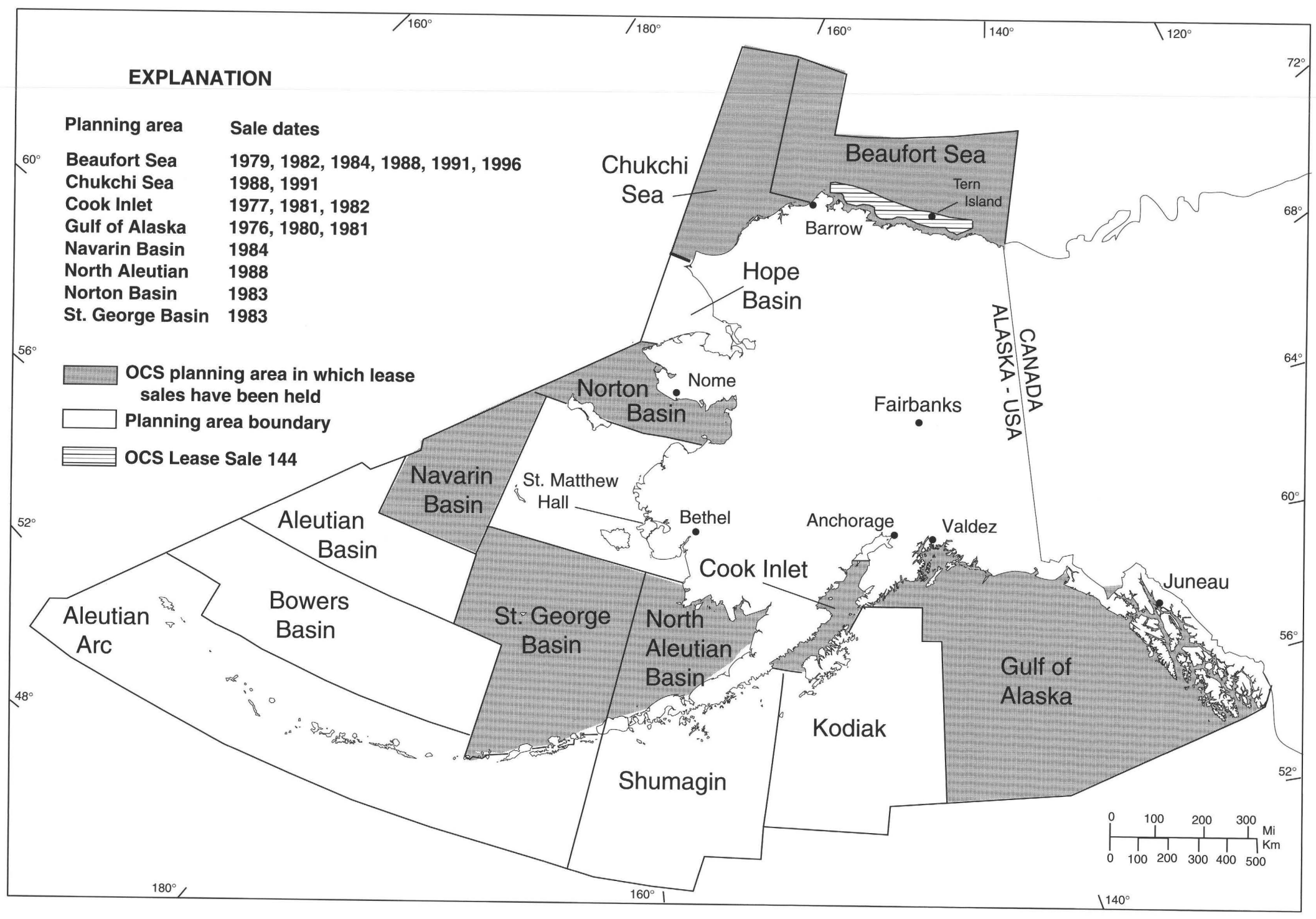

Figure 9. Alaska Region OCS planning areas, lease sale history, and location of OCS Lease Sale 144. 
Table 4. Proceeds from lease sales on Alaska Region OCS planning areas, 1976-1996.

\begin{tabular}{|c|c|c|c|c|}
\hline Planning area & Sale & Year & $\begin{array}{l}\text { Leases } \\
\text { awarded }\end{array}$ & $\begin{array}{l}\text { Proceeds } \\
\text { (dollars) }\end{array}$ \\
\hline \multirow[t]{6}{*}{ Beaufort Sea } & $\mathrm{BF}^{1}$ & 1979 & 24 & $488,691,138$ \\
\hline & 71 & 1982 & 121 & $2,055,632,336$ \\
\hline & 87 & 1984 & 227 & $866,860,327$ \\
\hline & 97 & 1988 & 202 & $115,261,636$ \\
\hline & 124 & 1991 & 57 & $16,807,025$ \\
\hline & 144 & 1996 & 29 & $14,429,363$ \\
\hline \multirow[t]{3}{*}{ Cook Inlet ${ }^{2}$} & CI & 1977 & 87 & $398,471,313$ \\
\hline & 60 & 1981 & 13 & $4,405,899$ \\
\hline & RS-2 & 1982 & 0 & 0 \\
\hline \multirow[t]{2}{*}{ Chukchi Sea } & 109 & 1988 & 350 & $478,032,631$ \\
\hline & 126 & 1991 & 28 & $7,117,304$ \\
\hline \multirow[t]{3}{*}{ Gulf of Alaska } & 39 & 1976 & 76 & $559,836,587$ \\
\hline & 55 & 1980 & 35 & $109,751,073$ \\
\hline & RS-1 & 1981 & 1 & 170,496 \\
\hline Navarin Basin & 83 & 1984 & 163 & $516,317,331$ \\
\hline $\begin{array}{l}\text { North Aleutian } \\
\text { Basin }\end{array}$ & 92 & 1988 & 23 & $95,439,500$ \\
\hline Norton Basin & 57 & 1983 & 59 & $317,873,372$ \\
\hline St. George & 70 & 1983 & 96 & $426,458,830$ \\
\hline \multicolumn{5}{|l|}{ Basin } \\
\hline \multicolumn{2}{|c|}{ TOTALS } & & 1,591 & $6,471,556,161$ \\
\hline \multicolumn{5}{|c|}{$\begin{array}{l}{ }^{1} \text { Held jointly with the State of Alaska: sale revenues totaled } \\
\$ 1,056,082,635 . \\
{ }^{2} \text { Includes Lower Cook Inlet and Shelikof Straits. }\end{array}$} \\
\hline
\end{tabular}

Table 5. Alaska Region OCS leases and wells drilled, 1976-1996.

[EXPL, exploratory; COST, continental offshore stratigraphic test]

\begin{tabular}{lrrrc}
\hline Planning area & $\begin{array}{c}\text { Tracts } \\
\text { leased }\end{array}$ & $\begin{array}{c}\text { EXPL } \\
\text { wells }{ }^{1}\end{array}$ & $\begin{array}{c}\text { COST } \\
\text { wells }{ }^{1}\end{array}$ & $\begin{array}{c}\text { Active } \\
\text { leases }\end{array}$ \\
\hline Beaufort Sea & 660 & 28 & 0 & 80 \\
Chukchi Sea & 378 & 4 & 0 & 0 \\
Cook Inlet ${ }^{2}$ & 100 & 13 & 1 & 0 \\
Gulf of Alaska & 112 & 12 & 1 & 0 \\
Kodiak ${ }^{3}$ & 0 & 0 & 6 & 0 \\
Navarin Basin & 163 & 8 & 1 & 0 \\
North Aleutian & & & & \\
$\quad$ Basin ${ }^{4}$ & 23 & 0 & 1 & 0 \\
Norton Basin & 59 & 6 & 2 & 0 \\
St. George & & 10 & 2 & 0 \\
$\quad$ Basin & 96 & & & \\
$\quad$ TOTALS & $\mathbf{1 , 5 9 1}$ & $\mathbf{8 1}$ & $\mathbf{1 4}$ & $\mathbf{8 0}$ \\
\hline
\end{tabular}

${ }^{1}$ All wells permanently plugged and abandoned.

${ }^{2}$ Includes Lower Cook Inlet and Shelikof Straits.

${ }^{3}$ No lease sales held.

${ }^{4}$ Exploratory drilling prohibited; leases surrendered on July 28, 1995.
(COST) wells and 81 exploratory wells have been drilled on the Alaskan OCS (table 5). COST wells were drilled to delineate the geologic framework and hydrocarbon potential of the basins penetrated; exploratory wells probed for oil and gas. For the third consecutive year, no exploratory wells were drilled in Alaska OCS planning areas in 1996. All of the Alaska OCS wells have been permanently plugged and abandoned.

Beaufort Sea planning area.-The 80 Alaska OCS oil and gas leases held by industry all lie within the Beaufort Sea planning area (table 5). Nine leases have been classified as producible (table 6), but only five are active. The Hammerhead, Kuvlum, Northstar, and Sandpiper prospects, which cover a total of 20 Federal leases, are being evaluated for development; Union Texas expects Kuvlum to yield 150 to 300 million barrels of oil, and BPXAk estimates that the Northstar unit contains between 100 and 200 million barrels of recoverable oil. OCS Sale 144 was held in the Beaufort Sea planning area in September 1996, and additional sales are proposed for 1998 and 2000. Chukchi Sea planning area.-OCS Sale 148, originally proposed for June 1997 in the Chukchi Sea planning area, was deferred to the next 5-year (1997-2002) schedule due to low industry interest. A sale is proposed for 2002 in the Chukchi Sea and Hope Basin planning areas. Cook Inlet planning area.- Although no Federal leases were active in this area at the end of 1996, refined seismic technology, the discovery of new prospects, improved drilling and production techniques, and increased

Table 6. Producible oil leases, Beaufort Sea planning area, as of December 31, 1996.

[As defined by MMS regulations at 30 CFR 250.11, a "producible" lease is one from which oil, gas, or both can be produced in quantities sufficient to yield, after completion of the well, a return in excess of the costs of producing hydrocarbons at the wellhead; R-19XX, year relinquished]

\begin{tabular}{|c|c|c|c|}
\hline $\begin{array}{l}\text { Prospect } \\
\text { name }\end{array}$ & $\begin{array}{l}\text { Lease } \\
\text { number }\end{array}$ & $\begin{array}{l}\text { Lease } \\
\text { status }\end{array}$ & $\begin{array}{l}\text { Number of } \\
\text { wells drilled }\end{array}$ \\
\hline Seal ${ }^{1}$ & OCS-Y-0181 & Active & 1 \\
\hline Salmon & OCS-Y-0191 & R-1988 & 2 \\
\hline Tern & OCS-Y-0195 & R-1990 & 1 \\
\hline Tern & OCS-Y-0196 & R-1990 & 1 \\
\hline Tern & OCS-Y-0197 & R-1990 & 1 \\
\hline Sandpiper & OCS-Y-0370 & Active & 1 \\
\hline Sandpiper & OCS-Y-0371 & Active & 1 \\
\hline Hammerhead & OCS-Y-0849 & Active & 2 \\
\hline Kuvlum & OCS-Y-0866 & Active & 2 \\
\hline
\end{tabular}


oil production on State leases have contributed to the revitalization of hydrocarbon exploration and development in the Cook Inlet basin. In response to this interest, OCS Sale 149 in the Lower Cook Inlet area was scheduled for June 1996 (Minerals Management Service, 1996c); however, the sale was reduced in area and deferred until June 1997 due to environmental concerns expressed by the State. Another sale is proposed for 2001.

Gulf of Alaska planning area.-OCS Sale 114 was postponed in May 1989 to allow additional time to assess the effects of the Exxon Valdez oil spill. OCS Sale 158 was tentatively scheduled for June 1997 in the Yakutat area of the Gulf of Alaska planning area (Minerals Management Service, 1995b), but the sale was deferred due to low industry interest. OCS Sale 179 is proposed for 2001.

North Aleutian Basin planning area.-OCS Sale 92 in the North Aleutian Basin planning area was completed in October 1988, but a 1-year moratorium and suspension of operations was initiated in 1989 to allow time to assess consequences from the Exxon Valdez oil spill and to evaluate possible effects of oil development on Bristol Bay fisheries. After six consecutive moratoria and suspensions, the lease owners sued the Federal Government for breach of contract; in mid-1995, the affected companies agreed to surrender their leases for due compensation. No leases remain in effect, and the moratoria precluded any exploratory drilling.

Saint George Basin planning area.-The leases awarded in OCS Sale 70 are no longer active, and two subsequent sales in the Saint George Basin planning area have not been held due to low industry interest. OCS Sale 153 , scheduled for 1996, has been deferred indefinitely.

\section{FUTURE LEASE SALES}

The OCS Lands Act requires that the DOI prepare 5 -year programs that specify the size, location, and scheduling of areas to be assessed for Federal offshore natural gas and oil leasing. For the 1997-2002 program, the MMS established the Alaska Regional Stakeholders Task Force to provide input into which Alaska OCS planning areas should be considered for lease sales. A comprehensive program for the management and leasing of natural gas and oil on the Alaska OCS was prepared (Minerals Management Service, 1995c), and the draft EIS was released for public hearings and comments (Minerals Management Service, 1996d). The proposal limited the amount of acreage offered for lease by excluding areas where resource potential and industry interest were low. In the proposed final program (Minerals Management Service, 1996e ), five sales were to be considered during the 1997-2002 program (table 7); the Chukchi Sea and Hope Basin proposals constitute a single sale. Studies planned for the 1997-2002 program will focus on
Table 7. Proposed activity for Alaska Region OCS planning areas, 1997-2002.

[Data from Minerals Management Service (1996e)]

\begin{tabular}{lc}
\hline $\begin{array}{l}\text { Region and } \\
\text { planning area }\end{array}$ & $\begin{array}{c}\text { Leasing } \\
\text { considered }\end{array}$ \\
\hline Aleutian Arc & No \\
Aleutian Basin & No \\
Beaufort Sea & 1998,2000 \\
Bowers Basin & No \\
Chukchi Sea & ${ }^{2}$ \\
Cook Inlet & \\
Gulf of Alaska & 2002 \\
Hope Basin ${ }^{2}$ & 2001 \\
Kodiak & 2001 \\
Navarin Basin & 2002 \\
North Aleutian Basin & No \\
Norton Basin & No \\
Saint George Basin & No \\
Saint Matthew-Hall & No \\
Shumagin & No \\
\hline${ }^{1}$ Specific sale dates will depend upon the outcome \\
of the Area Evaluation and Decision Process. \\
${ }^{2}$ A single sale will offer leases in both the Chukchi Sea \\
and Hope Basin planning areas. \\
${ }^{3}$ Includes Lower Cook Inlet and Shelikof Straits.
\end{tabular}

hydrocarbon potential and environmental characteristics of the areas.

ENVIRONMENTAL STUDIES PROGRAM

The Alaska Environmental Studies Program (AESP) was created by the DOI in 1974 in response to the Federal Government's decision to lease areas of the Alaska OCS for gas and oil development. Administered by the MMS, the purpose of the AESP is to determine information needs and implement studies to assist in predicting, assessing, and managing the potential effects of oil and gas exploration and development on the human, marine, and coastal environments of Alaska and the Alaska OCS. Assessment information is provided to the AESP through cooperative Federal and State interagency agreements and direct MMS contracts with private enterprises. More than half of the $\$ 500$ million spent on the national Environmental Studies Program has funded AESP studies in the 15 planning areas of the Arctic, Bering Sea, and Gulf of Alaska subregions.

The initial objective of the AESP was to obtain baseline information on the physical characteristics and biological resources of the Alaskan environment, using studies of basic oceanography and meteorology, investigations of geologic and sea-ice phenomena, and 
biological surveys of marine species. As the OCS leasing program accelerated in the late 1970's and early 1980's, the emphasis of AESP studies shifted to the potential effects of oil contamination on biological resources and to the probable transport and dispersion of oil that might be spilled in the marine environment. Because the Alaska OCS leasing program has matured and significant exploration activity has declined, the current mission of the AESP is to conduct postlease studies to monitor the possible effects of oil and gas exploration and drilling activities on the OCS environment and its resources. AESP studies can be categorized into several broadly defined subjects: living resources, endangered species, environmental geology, ecosystems, pollutant transport, environmental monitoring, oil spill fate and effects, and social and economic studies. Descriptions of ongoing and proposed AESP studies for 1996 and 1997 have been published (Minerals Management Service, 1994).

\section{OIL AND GAS RESOURCE ASSESSMENT}

The MMS prepares estimates of the undiscovered, economically recoverable oil and gas resources on the OCS as part of the Federal National Oil and Gas Resource Assessment. The new national (Minerals Management Service, 1996a) and Alaska (Sherwood, Craig, and Cooke, 1996) assessments were published in 1996. These reports include both a geologic evaluation of the undiscovered oil and gas resources and an economic appraisal of the undiscovered recoverable resources with regard to fluctuating market conditions.

\section{DATA ACQUISITION ON THE ALASKA OCS}

As in 1995, geophysical operations in 1996 were geared primarily toward prospect and play definition on nearshore lands in the Beaufort Sea. Although there have been recent discoveries in the area, the high cost of data acquisition and the unfavorable economic conditions for small field development have kept exploration efforts at low levels. Approximately 510 square kilometers of threedimensional seismic data were acquired in programs over State and Federal lands in the Beaufort Sea in 1996.

\section{U.S. GEOLOGICAL SURVEY}

Research on the North Slope, the study of petroleum systems and gas hydrates, and the assessment of undiscovered oil and gas resources are the principal USGS activities directed at an improved understanding of onshore oil and gas resources in Alaska. During 1996, USGS scientists conducted fieldwork, performed laboratory analyses of samples collected in the field, prepared maps and reports, and published findings from earlier work.
Highlights of results were presented during 1996 at various technical meetings.

\section{THERMAL HISTORY OF ALASKA}

USGS scientists have worked to understand the thermal history of rocks in Alaska since the late 1980's. Using nearly 10,000 samples collected from 3,500 outcrops and 214 wells across the State, determinations of vitrinite reflectance and conodont color-alteration index were made (Johnsson and others, 1992), and a generalized thermal maturity map of Alaska was compiled (Johnsson and Howell, 1996a). The map portrays the thermal maturity of rocks exposed at the surface and, where data permit on the North Slope and in the Cook Inlet region, the configuration of the top of the oil generation zone in the subsurface. The map and data, in a geographical information system (GIS) format, provide a framework for interpretation of tectonic history and estimation of hydrocarbon potential throughout Alaska. A volume on the thermal maturity of sedimentary basins in Alaska (Johnsson and Howell, 1996b) presents an overview (Johnsson and Howell, 1996c) and series of reports on the thermal history of the Alaska Peninsula (fig. 10) (Molenaar, 1996), the Kandik region in east-central Alaska (Shelton and others, 1996; Underwood and others, 1996), and the North Slope (Deming, Sass, and Lachenbruch, 1996; O'Sullivan, 1996).

ARCTIC NATIONAL WILDLIFE REFUGE

Helicopter-supported fieldwork was conducted in and adjacent to the northern part of the Arctic NWR in 1996. Samples were collected for apatite fission-track analysis and petroleum source- and reservoir-rock analysis, and observations were made of structural and sedimentologic features. A new evaluation of the oil and gas potential of the Arctic NWR Coastal Plain will be based on these studies.

A study of the age and depositional environments of the Lisburne Group in the Sadlerochit Mountains of Arctic NWR has been completed (Harris and others, 1997). Because the Lisburne Group hosts the main producing reservoir at the Prudhoe Bay Oil Field, 150 kilometers to the northwest, this study will help determine if rocks in Arctic NWR are also a potential oil reservoir.

\section{COOPERATIVE WORK WITH FOREIGN AGENCIES}

In 1996, the USGS formally agreed to participate with private industry and the Geological Survey of Canada in a project to evaluate the potential for gas-hydrate production in the Arctic. Also during 1996, reports were published on the assessment of gas-hydrate resources in the United States (Collett, 1996a), the source of surficial methane in northern Alaska (Collett, 1996b), and investigations of 


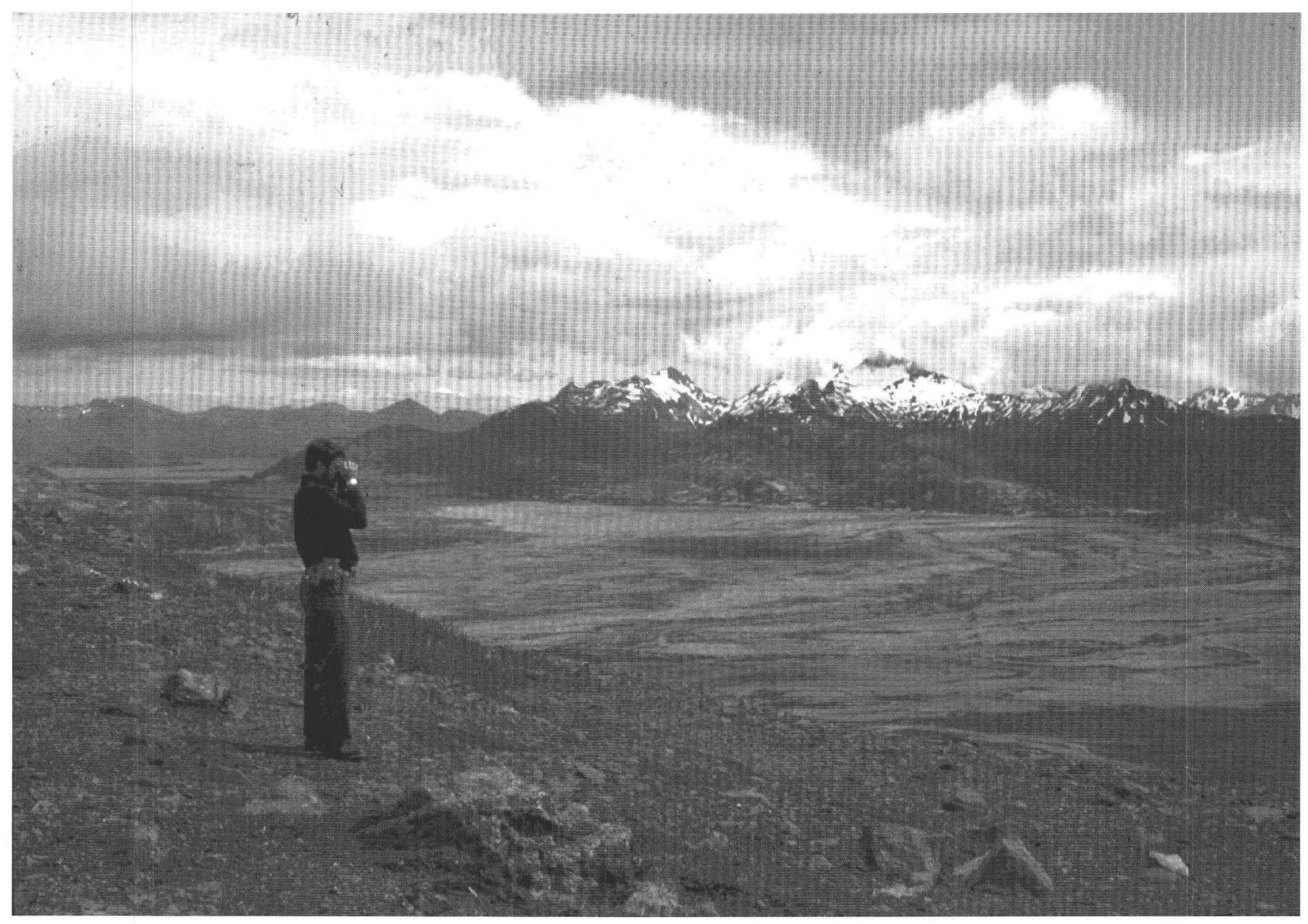

Figure 10. USGS geologist looks southwest across the Big River valley to Aleutian Range mountains north of Stepovak Bay. This area is included in an analysis of thermal maturity patterns of rocks on the Alaska Peninsula (Molenaar, 1996). The rocks underlying this area are abnormally hot, as evidenced by the Phillips Big River No.A-1 drill hole, which had a geothermal gradient of $60^{\circ} \mathrm{C}$ per kilometer of depth, well above the regional average of $37^{\circ} \mathrm{C}$ per kilometer. Photograph by F. H. Wilson, USGS.

seismic velocities in hydrate-bearing sedimentary rocks (Lee and others, 1996).

COOPERATIVE WORK WITH THE STATE OF ALASKA

The Alaska Division of Geological and Geophysical Surveys (ADGGS) designed a study to assess the petroleum potential of possible reservoir rocks in the northern foothills of the western Brooks Range. Fieldwork to collect data on the stratigraphy, sedimentology, and structure of Jurassic and Lower Cretaceous rocks in the DeLong Mountains was performed by the USGS in support of this study.

\section{OIL AND GAS ASSESSMENT}

The USGS released a report on the economics of undiscovered oil and gas resources in Alaska (Attanasi and
Bird, 1996). This report completes the onshore and State offshore part of the 1995 National Oil and Gas Resources Assessment (Gautier and others, 1995; U.S. Geological Survey, 1995a, 1995b).

\section{BUREAU OF LAND MANAGEMENT}

The BLM has primary responsibility for mineral leasing, for economic evaluation of mineral resources, and for appraisal of mineral estate values of federally managed lands in Alaska. Evaluation of mineral potential is a required component of all BLM Resource Management Plans and Federal lands dispositions. In addition, the mineral potential of BLM-administered lands must be studied in relation to development impacts both to and from activities on adjacent, non-Federal leaseholdings. BLM personnel systematically interpret geologic, geophysical, geochemical, mineral- 
resource, and economic data as they become available from private industry, State offices, and other Federal agencies. Proprietary information is held confidential in accordance with appropriate law and lease stipulations; nonproprietary data, interpretations, and assessments may be published as BLM-Alaska open-file or technical reports.

\section{LEASE OPERATIONS}

The BLM manages oil and gas leases on the Kenai Peninsula and North Slope under provisions of the National Petroleum Reserve Production Act and ANILCA. In 1996, the BLM administered 37 producing oil and gas leases on 264 square kilometers on the Kenai Peninsula. Additional production came from 0.65 square kilometers administered under a Compensatory Royalty Agreement, which prevents drainage and subsequent loss of Federal minerals; this agreement applied to the West Fork field, where two wells on private leases produce from neighboring Federal Estate. Royalty revenues from Federal onshore oil and gas production in Alaska rank tenth in the United States.

The BLM also managed 126 nonproducing leases that cover 16 square kilometers in four areas south of $68^{\circ}$ N. (fig. 11): Denali-Tiekel-Slana, Iditarod-George, Minchumina, and the Seward Peninsula. The four areas were made available for oil and gas leasing in compliance with section 1008 of ANILCA. As such, any exploration, development, or production activities on these lands are to be managed under the Federal Onshore Oil and Gas Leasing Reform Act of 1987 and the Energy Policy Act of 1992.

Five Applications for Permit to Drill were issued for the Kenai Peninsula: three for development wells in the Swanson River Gas Field, and two for exploratory wells. All of the Producing Areas in the Swanson River field were redefined to optimize development potential for the field; nine new gas pools were identified and added to the Tyonek Participating Area. The two exploratory wells, Corea Creek and Bufflehead, were both wildcat wells that were plugged and abandoned after testing and inspection. A request for a seismic exploration program near the Corea Creek well was processed.

The BLM's Inspection and Enforcement (I\&E) program guides leasehold operations associated with exploration, development, and production of oil and gas from Federal onshore lands; all active leases are located on the Kenai NWR. I\&E strategy evolves to reflect changing technical and economic conditions. Factors affecting I\&E strategy include determination of reservoir volumes, disposition of ancillary resources, and legal mandates. Data pertaining to these factors are tracked by the Automated Inspection Records System. The BLM and AOGCC met to discuss the feasibility of transferring the I\&E field functions to the State of Alaska.
RESOURCE EVALUATION

Arctic National Wildlife Refuge.-BLM investigations showed that oils from three distinct petroleum systems are present under the Arctic NWR Coastal Plain (Banet, 1995; Banet and Mowatt, 1996). The BLM assisted the USGS in reviewing geologic, geochemical, and seismic data for an updated USGS assessment of Coastal Plain reserves. For an FWS report on calving activities of the Porcupine caribou herd on the Coastal Plain, the BLM compiled maps comparing high-density calving areas with areas having highest potential for economically recoverable oil and gas resources (Banet, 1997). The BLM also briefed the FWS and DOI representatives on the potential for drainage under the Coastal Plain from any wells drilled on offshore lands adjacent to Arctic NWR.

National Petroleum Reserve-Alaska.-The BLM conducted briefings for DOI representatives concerning possible oil and gas lease sales in NPRA. These briefings described NPRA and its current relation to existing oil and gas developments and infrastructure. Topics included status of mineral estate, potential recoverable oil resources, types and disposition of exploration targets, tract selection and evaluation processes, concerns over possible drainage of resources by development of the Alpine Oil Field, other mineral resources, and environmental and wildlife resources.

Other--The BLM advised the FWS on conducting an assessment of leasable minerals in the Yukon Flats NWR, pertinent to a proposed land exchange. Leasable mineral reports were also prepared for six tracts of BLM lands proposed for sales in southwestern Alaska (two tracts) and in south-central Alaska (four tracts).

\section{PIPELINE MONITORING}

The JPO consolidates activities of 11 State and Federal regulatory agencies having specific and complimentary authorities. The JPO facilitates reviews of oil-spill contingency plans and promotes awareness of oilspill impacts and remediation activities. JPO's organizational structure includes Operations, Quality Assurance, Pipeline Surveillance, Engineering, Lands Administration, and a self-directed Oil Spill Team.

In April, a leak was discovered in TAPS near Pump Station 10 in east-central Alaska, and the JPO coordinated the clean-up and recovery of approximately 476 barrels of North Slope crude oil that had leaked from a faulty fitting on a bypass line. In November, lowered TAPS throughput produced increased flow turbulence in the oil descending Thompson Pass north of Valdez, which caused separation of the oil into liquid and vapor phases; collapse of the vapor 


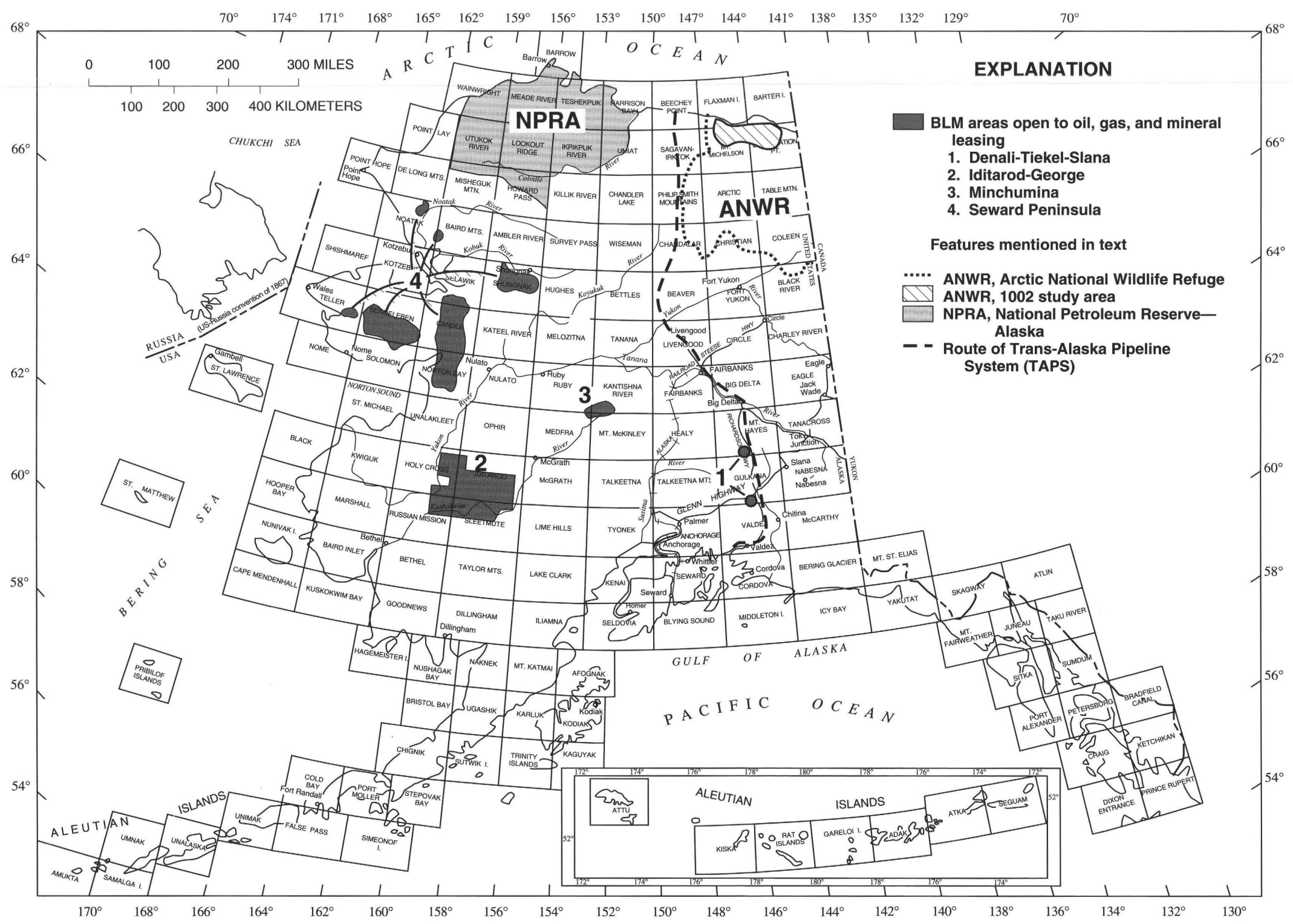

Figure 11. Selected Federal land units mentioned in text. 1:250,000-scale quadrangles are outlined and labeled. 
phase at the bottom of the pass produced a shock effect that was both felt and heard by observers along this section of TAPS. Testing at the site revealed no leakage from TAPS, but the JPO contracted an independent lab to assess TAPS engineering throughout this section of the route.

In 1996, the JPO received the Governor's special Excellence in Government Service Award for Compliance Monitoring, which assures open communications between the JPO, Alyeska Pipeline Service Company, and the North Slope Borough, and which allows each organizational section to exercise its authority in maintaining pipeline monitoring programs. The JPO also received favorable comments in an audit by the U.S. Department of Transportation for effectiveness in working with Alyeska Pipeline Service to correct deficiencies noted in TAPS audits.

\section{NATIONAL PARK SERVICE}

In 1996, the NPS commented on the draft EIS for the proposed OCS oil and gas leasing program, 1997-2002 (Minerals Management Service, 1996d). In its remarks, the NPS requested special recognition for the environmental resources associated with Federal and State reserves located in coastal areas affected by future lease activities. Sales proposed by the MMS could potentially affect the Aniakchak, Bering Land Bridge, Cape Krusenstern, Glacier Bay, Katmai, and Kenai Fjords units of the National Park System in Alaska (fig. 3).

\section{U.S. FISH AND WILDLIFE SERVICE}

KENAI NATIONAL WILDLIFE REFUGE

The Kenai NWR is the only refuge in Alaska where commercial oil and gas production is currently permitted. Surface operations are regulated by the FWS, and subsurface activities by the BLM. Data for 1996 production from the refuge's Swanson River and Beaver Creek Oil Fields are included in table 1.

A diesel fuel spill was discovered in 1990 in the Beaver Creek field, which is operated by Marathon Oil; the company's remediation plan was approved by the FWS, BLM, and Alaska Department of Environmental Conservation (ADEC) in 1994. Most of the fuel appears to have been recovered, but remediation will continue until the ADEC grants closure approval.

At the Swanson River Oil Field, an aromatic hydrocarbon spill was discovered in the pipe and supply yard in 1988. Initial efforts in 1990 to remove hydrocarbons from groundwater were successful, but the procedure is complex, and work continued in 1996; the FWS supports the cleanup levels established by the ADEC. A comprehensive review of remediation efforts at the yard was completed by the field operator in early 1995, and remediation was expected to continue through 1997. Also at the Swanson River field, an environmental audit was completed in 1991 of chronic crude oil spills and leaks at tank settings and flare pits. A remediation pilot project initiated in 1992 at one of the tank settings was expected to continue through 1997. Cleanup levels are being achieved, but a decision has not yet been made as to applicability for the remaining tank settings and flare pits. Unocal took over operation of the Swanson River field from ARCO-Ak in 1992.

The Bufflehead exploratory well was drilled north of the Swanson River Unit boundary in 1995 and 1996 by ARCO-Ak and the Cook Inlet Regional Corporation. Site closure was initiated in early July 1996, and the well was officially plugged and abandoned in early August.

\section{ACTIVITIES UNDER SECTION 1008 OF ANILCA}

Section 1008 of ANILCA provides for oil and gas studies on refuges in Alaska in order to gather information for use in future land-management decisions. In 1996, eight special-use permits were issued for minerals activities on the following national wildlife refuges in Alaska (number of permits in parentheses): Alaska Maritime-volcano studies (1), geologic exploration (1); Arctic-surface geology (1), glacier research (1), investigation of glacial deposits (1); and Izembek-geologic mapping with helicopter access (1), geologic mapping and installation of seismic station (1), geologic studies related to history of glaciation (1). All special-use permits include specific stipulations to ensure that the permitted activities remain compatible with the purposes of the refuge and to protect refuge resources and refuge users. Commercial permittees must post bonds. For oil and gas exploration on refuge lands, a report with specific data requirements must be submitted following the end of the permit authorization period. All data submitted are kept confidential to the extent permitted by law. The data may be used by the DOI in responding to Congress, but they will not be published.

\section{RESOURCE ACTIVITY IMPACT ASSESSMENT \\ Permitting.-Under Section 404 of the Clean Water} Act (CWA), Public Notice permits are required for certain activities on public and private lands and waters. In 1996, the FWS reviewed 28 CWA permit applications pertaining to oil and gas activities off refuges. These Public Notices included development and production operations at the Kuparuk, Lisburne, Milne Point, Point McIntyre, and Prudhoe Bay Oil Fields, as well as on TAPS. New developments were reviewed on the Colville River delta, onshore in Mikkelsen Bay, and offshore north of Storkersen Point for the Northstar Unit.

Lease Sales.-The FWS reviewed and commented 
on Federal OCS Lease Sales 144 and 177, both in the Beaufort Sea. The FWS also reviewed three proposed State offshore lease sales along the North Slope.

Monitoring.-In cooperation with the Environmental Protection Agency (EPA), the FWS collected snow samples in northern and northwestern Alaska for contaminant analysis. Results were to be compared to analyses of similar samples collected in and near the North Slope oil fields. In 1996, the FWS completed a 5-year bird banding project and a 2-year study of the impact of oil and gas facilities on the movement of Pacific black brant and their broods. Contaminant sampling of king and Steller's eiders found near Barrow was completed in 1996, and sample analysis was scheduled for 1997. A second year of monitoring nesting common eiders in Kasegaluk Lagoon was completed in 1996; the lagoon is monitored because it has been identified as a possible site for oil-development support facilities if oil were to be discovered in the Chukchi Sea.

ACTIVITIES UNDER SECTIONS 302 AND 303 OF ANILCA

Sections 302 and 303 of ANILCA stipulate that the FWS manage water quality and quantity in each refuge for the conservation of fish and wildlife and their habitats. Due to ongoing and possible oil and gas activities, 5-year waterresource inventories and assessments have been initiated in four refuges. In the Kenai NWR, where oil and gas are produced from the Swanson River and Beaver Creek Oil Fields, 15 stream-gaging stations were installed in 1994 and 1995. Two of these were destroyed by floods in late 1995 , and three were destroyed by bears. All damaged equipment was replaced in 1996, and the gages were restored to operating condition. In the Yukon Flats NWR, 11 stream-gaging stations were maintained (fig. 12). In 1996, two stations were installed on the Becharof NWR, and eight were installed on the Innoko NWR.

\section{REGULATION}

Section 101(a)(5) of the Marine Mammal Protection Act gives the Secretary of the Interior the authority to allow, on request by U.S. citizens engaged in a specified activity (other than commercial fishing) in a specified geographic region, the incidental, but not intentional, taking of small numbers of marine mammals. The rulings governing such authorizations are area-specific and are issued for 5 years. Under the implementing regulations, the FWS may issue Letters of Authorization (LOA's), with appropriate conditions, to those applicants requesting them. In accordance with the Marine Mammal Protection Act, monitoring and reporting programs are required for each LOA.

In 1996, two FWS rulings concerning the incidental take of marine mammals during oil and gas activities were active in Alaska. Regulations at 56 CFR 27443 authorized the incidental, but not intentional, take of small numbers of polar bears and Pacific walrus during open-water oil and gas exploration in the Chukchi Sea. These regulations expired in June 1996 and were not reissued due to a lack of industry interest. Regulations at 58 CFR 60402 and 60 CFR 42805 authorized the incidental, but not intentional, take of small numbers of polar bears and Pacific walrus during oil and gas industry operations (exploration, development, and production) year-round in the Beaufort Sea and adjacent coast of Alaska. These regulations were enacted in November 1993 and are authoritative through December 15, 1998. In 1996, nine LOA's were issued for the Beaufort Sea and adjacent northern coast of Alaska (table 8).

One FWS authorization for the intentional take (harassment only) of polar bears was issued in 1996. This ruling allows deterrent actions to prevent bears from endangering human life during oil and gas activities in the Beaufort Sea and adjacent oil fields.

EXXON VALDEZ OIL SPILL RESTORATION PROJECT

The FWS continued its investigations of the impacts of the Exxon Valdez oil spill on marine birds and mammals. 1995 project results (Kuletz, 1996) and 1996 project descriptions (Exxon Valdez Oil Spill Trustee Council, 1996) were published. A Seabird Restoration Workshop was held (Warheit, Harrison, and Divoky, 1997), and one restoration project issued its final report (Kuletz, Kendall, and Flint, 1996).

ARCTIC NATIONAL WILDLIFE REFUGE

Section 1002 of ANILCA sets out specific management constraints on the 6,070-square-kilometer area

Table 8. FWS Letters of Authorization issued in 1996.

[ARCO-AK, ARCO Alaska; BPX-Ak, BP Exploration Alaska; NGP, Northern Geophysical; WGP, Western Geophysical]

\begin{tabular}{|c|c|c|}
\hline Date & Company & Activity \\
\hline $5 / 15 / 96$ & BPX-Ak & Open water seismic survey \\
\hline $10 / 31 / 96$ & WGP & Winter vibroseis survey \\
\hline $10 / 31 / 96$ & NGP & Winter vibroseis survey \\
\hline $11 / 07 / 96$ & BPX-Ak & Exploration activities \\
\hline $12 / 10 / 96$ & BPX-Ak & $\begin{array}{l}\text { Year round oil and gas } \\
\text { operations }\end{array}$ \\
\hline $12 / 11 / 96$ & BPX-Ak & Exploration activities \\
\hline $12 / 20 / 96$ & $\mathrm{BPX}-\mathrm{Ak}$ & Development operations \\
\hline $12 / 24 / 96$ & WGP & Winter vibroseis survey \\
\hline $12 / 24 / 96$ & ARCO-Ak & Exploration activities \\
\hline
\end{tabular}




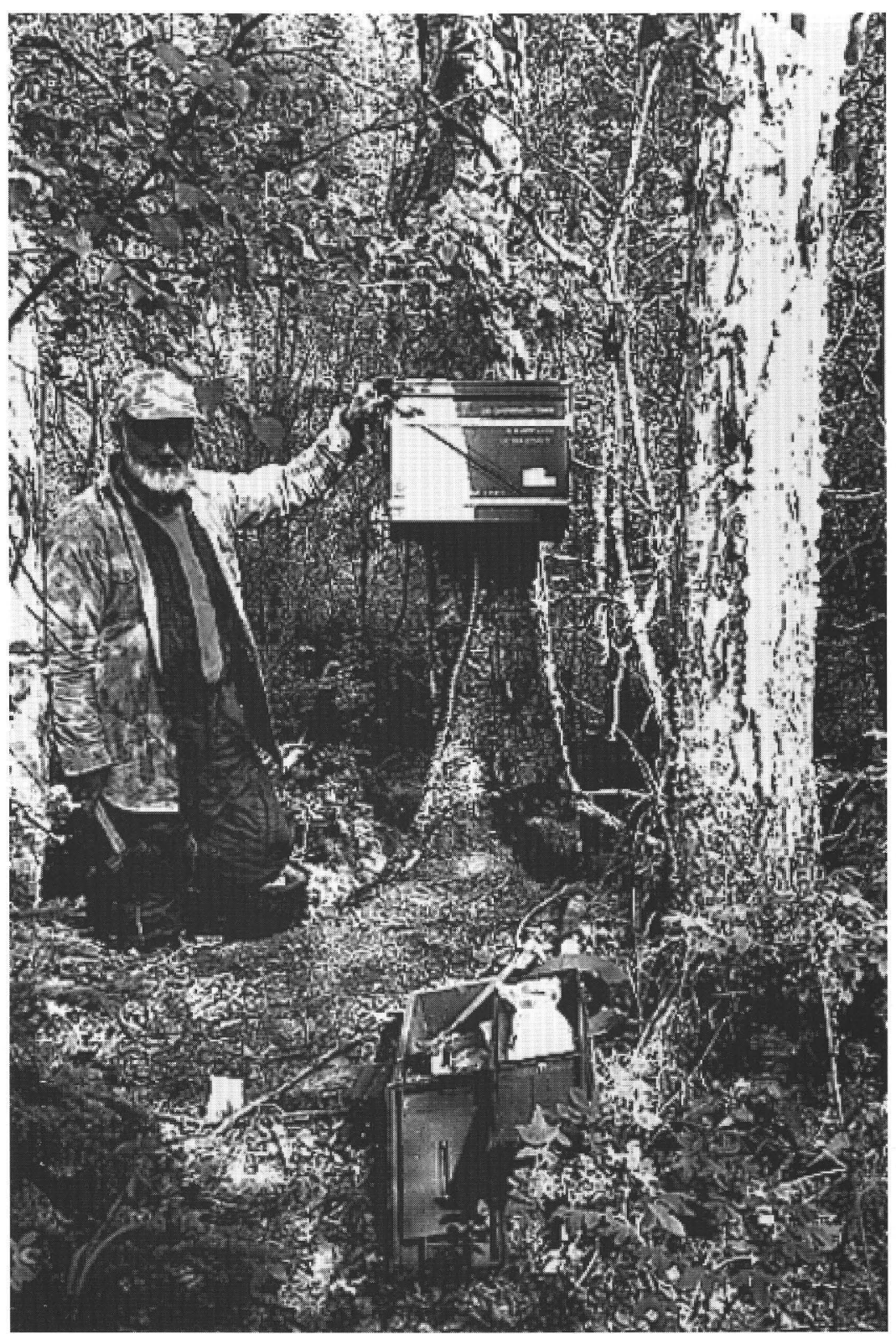

Figure 12. Stream-discharge gage on the Little Black River in Yukon Flats National Wildlife Refuge. An electrical conduit connects the tree-mounted data logger to a pressure transducer in a well in the streambank. The resultant data can be analyzed to provide information on quantity and speed of water flowing past this point in the stream. Photograph from FWS files.

in northwestern Arctic NWR defined as the Coastal Plain [16 USC 3142]; this strip is also known as the 1002 area (fig. 11). The FWS was designated as principal coordinator for a resource assessment required under ANILCA Section 1002 and subsequently conducted a baseline study of the area's fish, wildlife, and habitats. The Coastal Plain Resource Assessment summarized the area's fish, wildlife, and hydrocarbon resources; described the potential impacts of petroleum exploration and production; and outlined recommendations regarding possible oil and gas operations in the 1002 area, should they occur (Clough, Patton, and Christiansen, 1987). ANILCA Section 1003 prohibits oil and gas leasing or production in the Arctic NWR unless authorized by an act of Congress [16 USC 3143].

Additional field studies have been conducted since 1987 (U.S. Fish and Wildlife Service, 1995). In 1996, the FWS continued to monitor musk ox population dynamics, movements, and habitat use. The FWS also cooperated with the Alaska Department of Fish and Game to monitor caribou calving distribution, productivity, and early calf 
survival. Some studies initiated by the FWS were transferred to the National Biological Service in 1995 and to the USGS in 1996; a final report was being prepared. The final report on Coastal Plain fisheries (Underwood and others, 1995) and an adjunct report (Underwood, Millard, and Thorpe, 1996) were published.

A prototype lake elevation application was filed with the State of Alaska for water rights on Lake \#6 within the Coastal Plain. Criteria used to document the water rights application were published (Bayha, 1996). Ten additional lake applications were filed after review and approval of the prototype application by ADNR.

\section{U.S. DEPARTMENT OF ENERGY}

The DOE approved a 4-year cooperative research and development agreement with BP Exploration, Inc. (BPX) in 1995 to develop a recovery process for the heavy-oil component of the Prudhoe Bay Oil Field. The physical target of this research is an estimated 1.54 billion barrels of heavy oil contained in a 9- to 24-meter-thick layer that underlies the main oil-production zone in the southern part of the Prudhoe Bay field. BPX is contributing approximately $\$ 4.97$ million to the \$6.36-million project.

In 1996, laboratory research was conducted on oil and rock samples at the DOE's National Institute for Petroleum and Energy Research in Bartlesville, Oklahoma; studies included geochemical analyses; thin-section petrography; measurements of viscosity, density, and asphaltene content; and pressure-temperature experiments. Test results were analyzed to characterize the physical properties of the heavy oil for use in engineering simulations of proposed recovery methods. Should the results of laboratory research lead to an economically viable recovery process that is applicable to Prudhoe Bay's heavy-oil zone, BPX would then undertake a pilot study prior to initiating commercial operations.

\section{COAL AND PEAT RESOURCES}

The locations of coal deposits, mines, and areas of Federal agency activities described in this section are shown on figure 13; production statistics given in table 9 are derived from the State's preliminary report on 1996 mining activities (Swainbank and others, 1997).

\section{OVERVIEW OF PRODUCTION}

Alaska's 1996 coal production of 1.3 million metric tons was valued at $\$ 38$ million, an 11-percent decrease in volume and 8-percent decrease in value from 1995 levels. In contrast, total 1996 U.S. coal production increased 5 percent to a record high of 971 million metric tons. Coal totaled 6.5 percent of Alaska's mining production value in 1996.

The Usibelli Mine near Healy was the only active coal mine in the State and produced all commercial Alaskan coal from two open pits in the Nenana Coal Field (fig. 14). Approximately one-half of Alaskan coal was used in-state for power generation; the rest was exported to South Korea from a coal terminal in Seward. Other coal resources in Alaska include the Kuchiak Research Mine on the western North Slope, the Matanuska Coal Field northeast of Anchorage, and the Beluga Coal Field west of Cook Inlet.

Peat mined in Alaska is used solely in agriculture and greenhouses as a soil conditioner. Peat production increased 9 percent in 1996 to 29,053 cubic meters, valued at $\$ 175,000$. Fairbanks, Delta Junction, and Wasilla were the top peat-producing areas.

\section{COAL RESOURCES}

Arctic Slope Regional Corporation (ASRC) continued work at its Kuchiak Research Mine in the Deadfall Syncline of northwestern Alaska. Studies included safe mining methods, treatment of ore and mine wastes, protection of water quality, and postmining reclamation. Located along the Chukchi Sea between Point Lay and Cape Lisburne, the field contains approximately 2.7 billion metric tons of highrank coals that contain very little sulfur. ASRC was also investigating ocean transport of the coal to market directly from the mine site, rather than via overland conveyance.

The Matanuska Coal Field northeast of Palmer contains high-rank bituminous coals that have low sulfur and water contents and high heating value; two mines in the field are nearing development. The Alaska Office of Surface Mining issued a permit to Nerox Power Systems to reopen the underground Jonesville Mine near Sutton. Nerox planned to mine up to 363,000 metric tons per year from an estimated resource of 36 million metric tons. Usibelli Coal acquired an option to purchase the Wishbone Hill project from North Pacific Mining; the property is estimated to contain 14 million metric tons of surface-minable coal. Usibelli may blend this coal with their Healy coal to increase the heating value of the product for overseas markets.

The Beluga Coal Field is on the west side of Cook Inlet and contains over a billion metric tons of coal. Chuitna Coal Group and Beluga Coal Company hold State-owned leases in the eastern and western halves of the field, respectively. ADNR had approved the mining permit for the Chuitna Coal Mine in 1987, but the State Supreme Court ruled in 1991 that Chuitna needed to file additional permit 


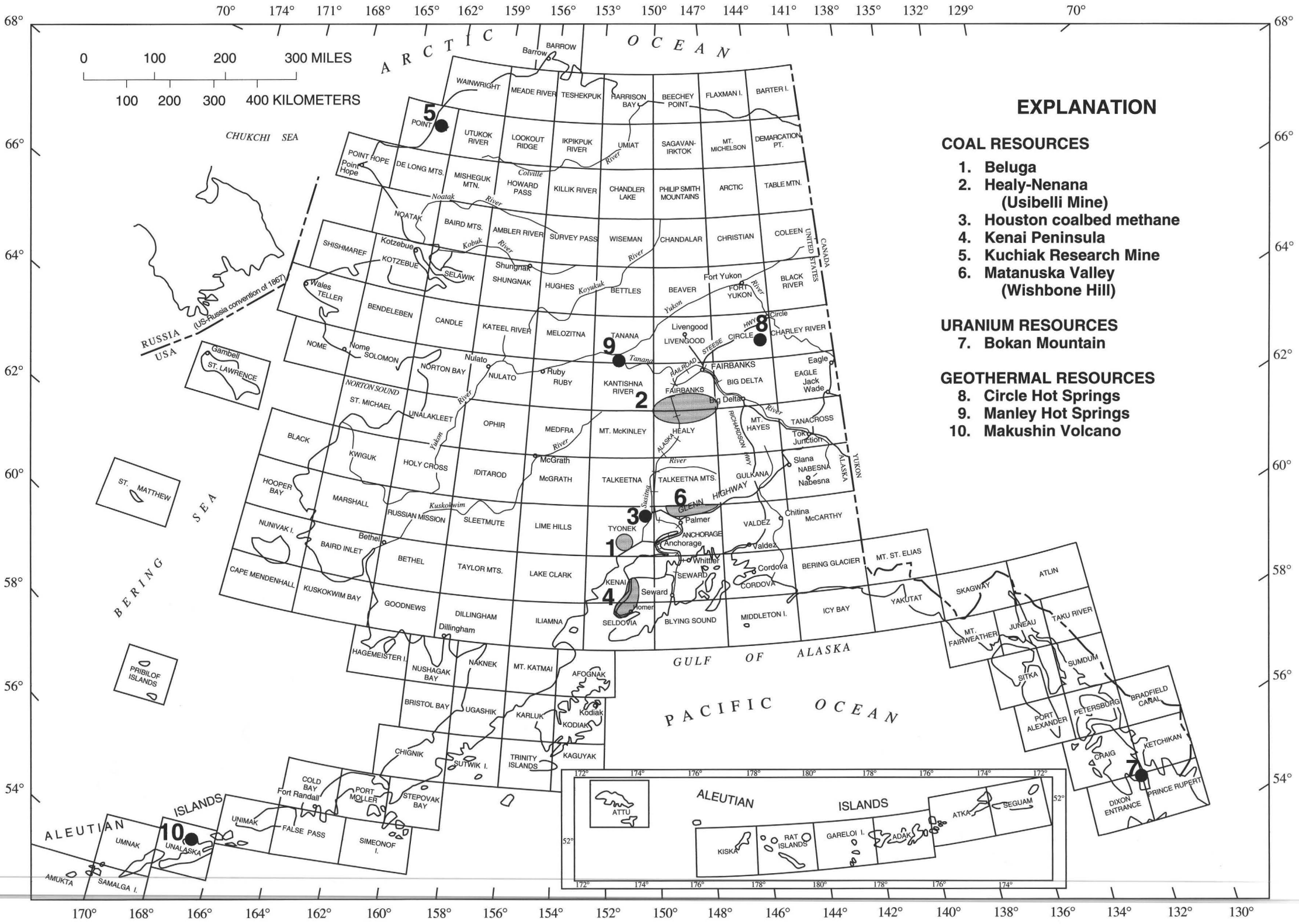

Figure 13. Areas of potential coal, uranium, and geothermal resources; industry activities; and agency activities mentioned in text. 1:250,000-scale quadrangles are outlined and labeled. 
Table 9. Mining production in Alaska, 1993-1996.

[Data from Swainbank and others (1997). Values calculated from 1996 price averages of zinc, lead, copper, gold, and silver, rounded to nearest thousand; other values supplied by mine operators]

\begin{tabular}{|c|c|c|c|c|c|c|c|c|}
\hline & \multicolumn{4}{|c|}{ VOLUME } & \multicolumn{4}{|c|}{ VALUE (x $\$ 1,000)$} \\
\hline & 1993 & 1994 & 1995 & 1996 & 1993 & 1994 & 1995 & 1996 \\
\hline Zinc (metric tons) & 243,823 & 298,466 & 326,541 & 332,737 & $\$ 236,517$ & $\$ 296,103$ & $\$ 345,552$ & $\$ 361,646$ \\
\hline Lead (metric tons) & 34,674 & 33,064 & 53,098 & 63,581 & 13,760 & 25,513 & 34,429 & 52,284 \\
\hline Copper (metric tons) & & & & 354 & & & & 803 \\
\hline Gold (kilograms) & 5,949 & 5,664 & 4,413 & 5,025 & 68,641 & 70,291 & 56,043 & 62,623 \\
\hline Silver (kilograms) & 176,013 & 61,212 & 38,124 & 114,336 & 24,334 & 10,391 & 6,656 & 19,078 \\
\hline $\begin{array}{l}\text { Sand and gravel } \\
\text { (million metric tons) }\end{array}$ & 12.0 & 12.3 & 8.9 & 9.0 & 40,637 & 40,951 & 30,887 & 32,203 \\
\hline $\begin{array}{l}\text { Building stone } \\
\text { (million metric tons) }\end{array}$ & 3.3 & 3.5 & 2.5 & 2.7 & 26,206 & 27,038 & 22,164 & 23,558 \\
\hline $\begin{array}{l}\text { Jade and soapstone } \\
\text { (metric tons) }\end{array}$ & 2.4 & 2.1 & 1.8 & 1.8 & 20 & 20 & 25 & 25 \\
\hline \multirow{3}{*}{$\begin{array}{l}\text { Coal (metric tons) } \\
\text { Peat (cubic meters) }\end{array}$} & $1,439,516$ & $1,351,705$ & $1,514,998$ & $1,343,540$ & 38,104 & 36,750 & 41,300 & 38,000 \\
\hline & 55,048 & 67,204 & 26,759 & 29,053 & 445 & 440 & 157 & 175 \\
\hline & & & & TOTALS & $\$ 448,664$ & $\$ \mathbf{5 0 7 , 4 9 7}$ & $\$ 537,213$ & $\$ 5 \mathbf{5 9 0 , 3 9 5}$ \\
\hline
\end{tabular}

applications for its proposed road, camp, and export terminal; the company was working to fulfill this requirement. Beluga Coal continued its option to use the existing Native-owned dock at Tyonek for exporting coal. Both companies would benefit from extension of the dock, an objective being pursued by Alyeska Alloys for its iron carbide exports (discussed in the "Production-Cook Inlet" section).

\section{HEALY CLEAN COAL PROJECT}

The Healy Clean Coal Project is one of 40 projects sponsored by the DOE in the United States being built to demonstrate new, clean-burning coal technologies that limit the emission of pollutants commonly cited as a cause of acid rain. The new 50-megawatt power plant will also contribute to energy resource conservation by burning a blend of Usibelli's commercial-grade coal and low rank, high-ash waste coal that could not normally be utilized. The \$267.2-million project, funded by the AIDEA and DOE, is also retrofitting the existing 25-megawatt power plant to lower the emissions of nitrogen oxides.

Construction of the new 50-megawatt plant was carried out from May to November of 1995, halted for the winter, then restarted in March 1996; construction and start-up testing was expected to be completed by late 1997 . After 18 months of testing and demonstration, full commercial operation is slated to begin in the summer of 1999. The bulk of this new electric-generating capacity will go to the Fort Knox Mine near Fairbanks.

\section{COALBED METHANE}

Coalbed methane is dry natural gas derived from coal seams. Matanuska Energy worked to develop its Coalbed Methane Project in the Houston area of southcentral Alaska. Project owners proposed to drill three 640meter-deep wells, which will intersect several coal beds and produce a total 17,000 cubic meters of gas per day. The company plans to develop similar coalbed methane wells in other parts of rural Alaska where the main energy source is high-priced diesel fuel.

Matanuska Energy also conducted geologic and economic studies to quantify the smallest Alaskan market that could be economically served by locally produced natural gas. Legislation was passed in 1996 to allow lowcost leasing and drilling on State-owned land solely for the development of shallow natural-gas resources within 914 meters of the surface. Potential coalbed gas reserves in Alaska have been estimated at 28 trillion cubic meters. 


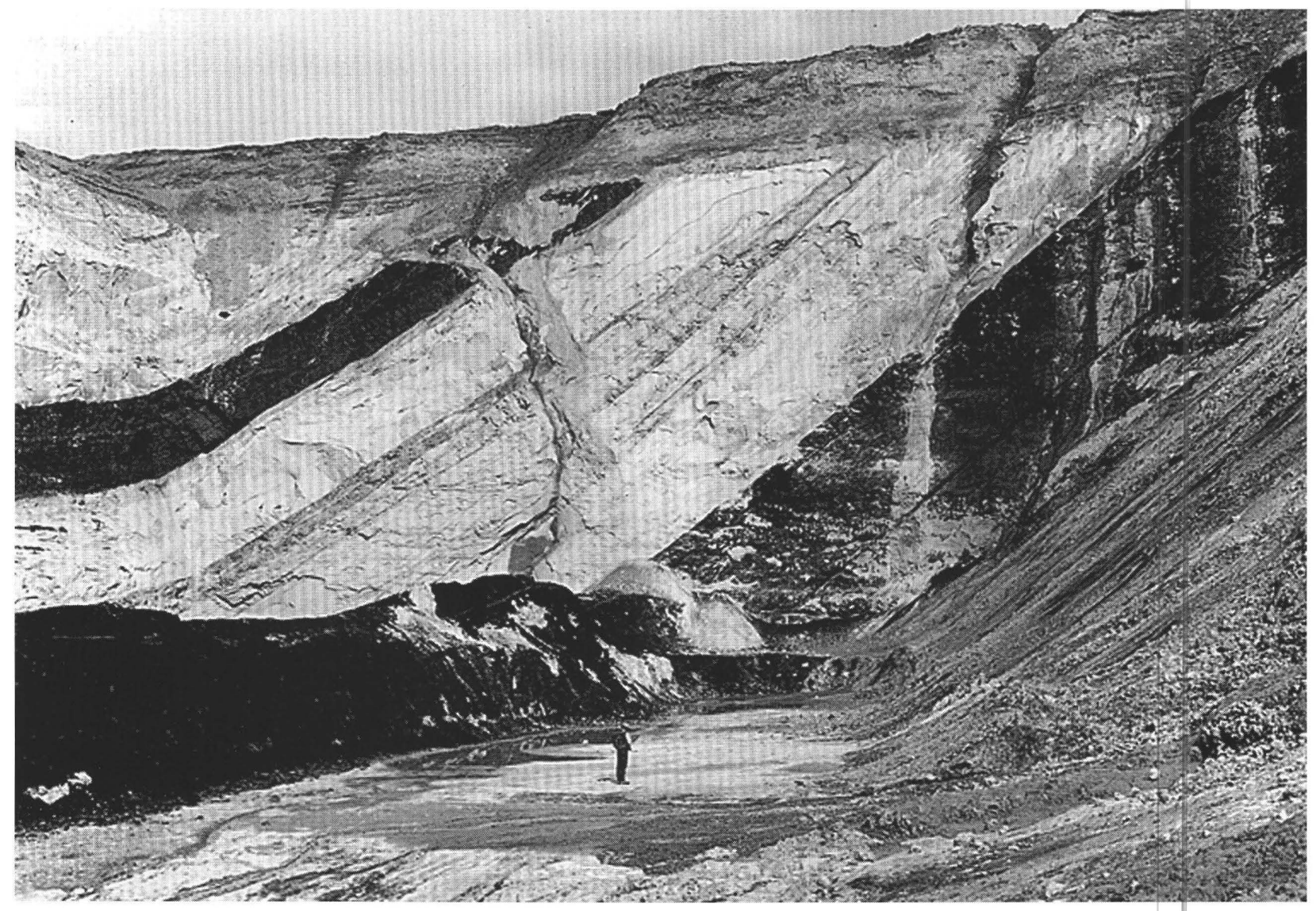

Figure 14. Coal seams in the Nenana Coal Field in east-central Alaska. Usibelli Coal operates the only commercial coal mine in Alaska, producing 1.3 million metric tons in 1996 from two open pits in the Nenana field. Photograph from USGS files.

\section{ACTIVITY BY FEDERAL AGENCIES}

\section{U.S. GEOLOGICAL SURVEY}

The USGS continued studies to compare and contrast the depositional environments of the coal-bearing Tyonek, Beluga, and Sterling Formations of the Kenai Group in south-central Alaska (Stricker and Flores, 1996). A study of coals in the Beluga Coal Field on the west side of Cook Inlet was completed (Flores, Stricker, and Stiles, 1997). USGS personnel also worked to quantify Alaska's coal resources for inclusion in the next National assessment.

\section{U.S. DEPARTMENT OF ENERGY}

HEALY CLEAN COAL PROJECT

The Healy Clean Coal Project is one of 40 DOE projects nationwide to demonstrate new and clean methods for burning coal while limiting the emission of pollutants commonly cited as a cause of acid rain. Using advanced combustion and flue-gas-cleanup technologies, the project is intended to illustrate the combined removal of particulate matter, nitrogen-oxide compounds, and sulfur dioxide from stack emissions. The Alaska Public Utilities Commission gave its approval to the project in September 1992, and the ADEC issued the necessary air-quality permit in early 1993. The DOE published the project's Final EIS in December 1993 (U.S. Department of Energy, 1993) and signed the Record of Decision in March 1994 to approve Federal funds to begin construction and operation of the project .

DOE funds of $\$ 117.3$ million are being provided under the Clean Coal Technology Program in a 1991 cooperative agreement monitored by the DOE's Federal Energy Technology Center in Pittsburgh. A consortium headed by the AIDEA will provide the remaining funds for the \$267.2-million project. The Healy Project, which is sited adjacent to the Golden Valley Electric Association's 
existing Healy Unit 1, will burn low-sulfur coal from the Usibelli Mine.

COAL-DIESEL PROJECT

The DOE is funding a second Clean Coal Technology demonstration project in Alaska at the University of Alaska-Fairbanks (UAF). The Coal-Diesel Project will install a 12-cylinder, 4.2-megawatt coal-fueled diesel engine for the generation of electricity at the UAF power plant; the engine will operate on a coal-water slurry prepared from coal mined by Usibelli Coal. The engine is expected to be 15 to 20 percent more efficient than conventional oil-fired boilers.

The project is being funded by $\$ 23.8$ million from DOE, $\$ 14$ million from UAF, $\$ 3.8$ million from the Alaska Science and Technology Foundation, and $\$ 3$ million in coal donated by Usibelli Coal. The Environmental Information Volume was prepared by the project managers in 1996; an Environmental Assessment document will also be completed. The DOE anticipated that the permitting process would be completed by mid1997.

\section{URANIUM RESOURCES}

No significant uranium exploration or development occurred in Alaska in 1996. In southeastern Alaska, limited exploration continued on claims at Bokan Mountain (fig. 13). Numerous uranium-thorium prospects there also hold potential for niobium and rare-earthelement production (Philpotts, Taylor, and Baedecker, 1996).

The USGS terminated its uranium program in 1994 and initiated research on radionuclide dispersal and its impact on the environment. In a volume on environmental mineral studies, the USGS summarized radioactivity concerns associated with uranium occurrences in Alaska and the abandoned Ross-Adams open-pit uranium mine at Bokan Mountain (Gray and Sanzolone, 1996).

\section{GEOTHERMAL RESOURCES}

Hot springs occur throughout Alaska and continue to be used locally for recreation, space heating, and agriculture; geothermally heated greenhouses are in operation at Circle Hot Springs and Manley Hot Springs. Widespread active volcanism in the Aleutian Islands and Alaska Peninsula sustains the potential for commercial geothermal energy production on a regional scale. A lease was active at the Makushin Valley geothermal area (fig. 13). No development occurred, but plans have been submitted to the Alaska Energy Authority for a 12megawatt geothermal power plant; the plant would furnish electrical power for Dutch Harbor and Unalaska, centers of the fishing industry in the northwestern Pacific Ocean. No Federal research was funded for geothermal studies in Alaska in 1996. 


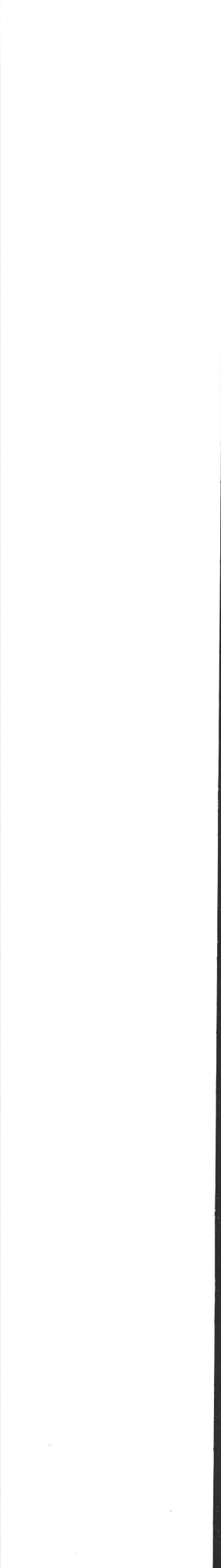




\section{- NONFUEL-MINERAL RESOURCES -}

\section{METALLIC MINERALS}

The locations of mines and mineral deposits discussed in the following review of industry activity are shown on figure 15; production data (table 9) and ore reserve statistics were derived from an annual report compiled by the ADGGS, Alaska Division of Mining and Water Management, and Alaska Division of Trade and Development (Swainbank and others, 1997). Federal activities related to many of these prospects are described under the appropriate agency heading following the industry review.

\section{ECONOMIC OVERVIEW}

The total value of Alaska's mineral industry exceeded \$1 billion in 1996, an increase of 43 percent from 1995 levels: production values rose 10 percent to $\$ 590$ million, exploration expenditures increased 30 percent to $\$ 44.5$ million, and development outlays almost tripled to $\$ 393.8$ million (Swainbank and others, 1997). At $\$ 496$ million, metallic minerals represented 84 percent of total mining production, and copper values were reported for the first time in 40 years. The Fort Knox gold mine near Fairbanks opened, and the Greens Creek polymetallic mine in southeastern Alaska reopened. Exploration efforts concentrated on lode gold near Fairbanks and in southwestern Alaska. Expansion and development work took place at the Greens Creek and Red Dog polymetallic mines and at the Fort Knox, Illinois Creek, Kensington, and Nixon Fork gold mines. The mining industry employed 3,760 people in 1996.

Zinc remained the most valuable metallic mineral at $\$ 361.6$ million, comprising 73 percent of metallic production and 61 percent of total mining production (table 9). The majority of zinc and lead was produced at the Red Dog Mine in northwestern Alaska, the world's largest zinc producer and contributor of 7 percent of worldwide zinc output in 1996. Improvements at the Red Dog mill allowed an increase in concentrate output while decreasing the amount of ore processed. Gold production, which had fallen when the Valdez Creek placer mine closed in late 1995, rebounded after two new lode-gold mines began production: the Nixon Fork Mine near McGrath and the Fort Knox Mine. Nixon Fork, Fort Knox, and the Alaska Gold placer near Nome were the top gold producers, contributing 48 percent of statewide output. Silver production also rebounded, after the Greens Creek Mine reopened in July 1996 and produced 67 percent of the State's silver. Copper was produced as a byproduct from both the Greens Creek and Nixon Fork Mines.

\section{LAND STATUS}

Land ownership in Alaska is divided among the Federal government ( 60 percent), the State and private entities (28 percent), and Alaska Native regional corporations (12 percent). On Federal lands, mineral activities are permitted in national forests, in BLM planning areas, and on grandfathered parcels in national parks, wildlife refuges, and wilderness areas. Federal agencies oversee and manage permitted mining activities on their respective lands and also deal with issues of access to, and environmental impacts from, adjacent, non-Federal lands. The Nixon Fork Mine is on BLM lands in western Alaska, and the Greens Creek, Jualin, and Kensington properties include NFS lands in southeastern Alaska.

Over 90 percent of State-owned land is open to mineral entry. In 1996, the State contracted airborne geophysical surveys in the Chulitna and Yentna Mining Districts of south-central Alaska, part of the Rampart Mining District in east-central Alaska, and the Bethel Basin in southwestern Alaska. The ADGGS also mapped the geology of the Rampart Mining District and the southern RubyPoorman Mining District. The Alaska Mental Health Trust (AMHT) Land Office issued four exploration permits: one to USMX Inc. in the Ophir Mining District, two to Placer Dome U.S. in the Chatanika and Livengood areas, and one to Teck Corporation in the Salcha block. The Fort Knox Mine in Fairbanks is also on AMHT lands. Alaska State mining claims increased 43 percent in 1996 to 36,002 (Swainbank and others, 1997); Federal mining claims totaled 9,642 .

The Alaska Native Claims Settlement Act in 1971 mandated conveyance of 161,875 square kilometers of land to 12 Alaska Native regional corporations; mineral values are one of the factors that influence final land decisions for some corporations. Many Native corporations are conducting or promoting mineral exploration and development on their lands: NANA Regional Corporation owns the Red Dog Mine in northwestern Alaska; Kennecott Exploration and Cominco American are exploring on Bering Straits Native Corporation lands on the Seward Peninsula; Placer Dome U.S. is exploring Donlin Creek on Calista Corporation lands in southwestern Alaska; and Consolidated Nevada Goldfields, WGM 


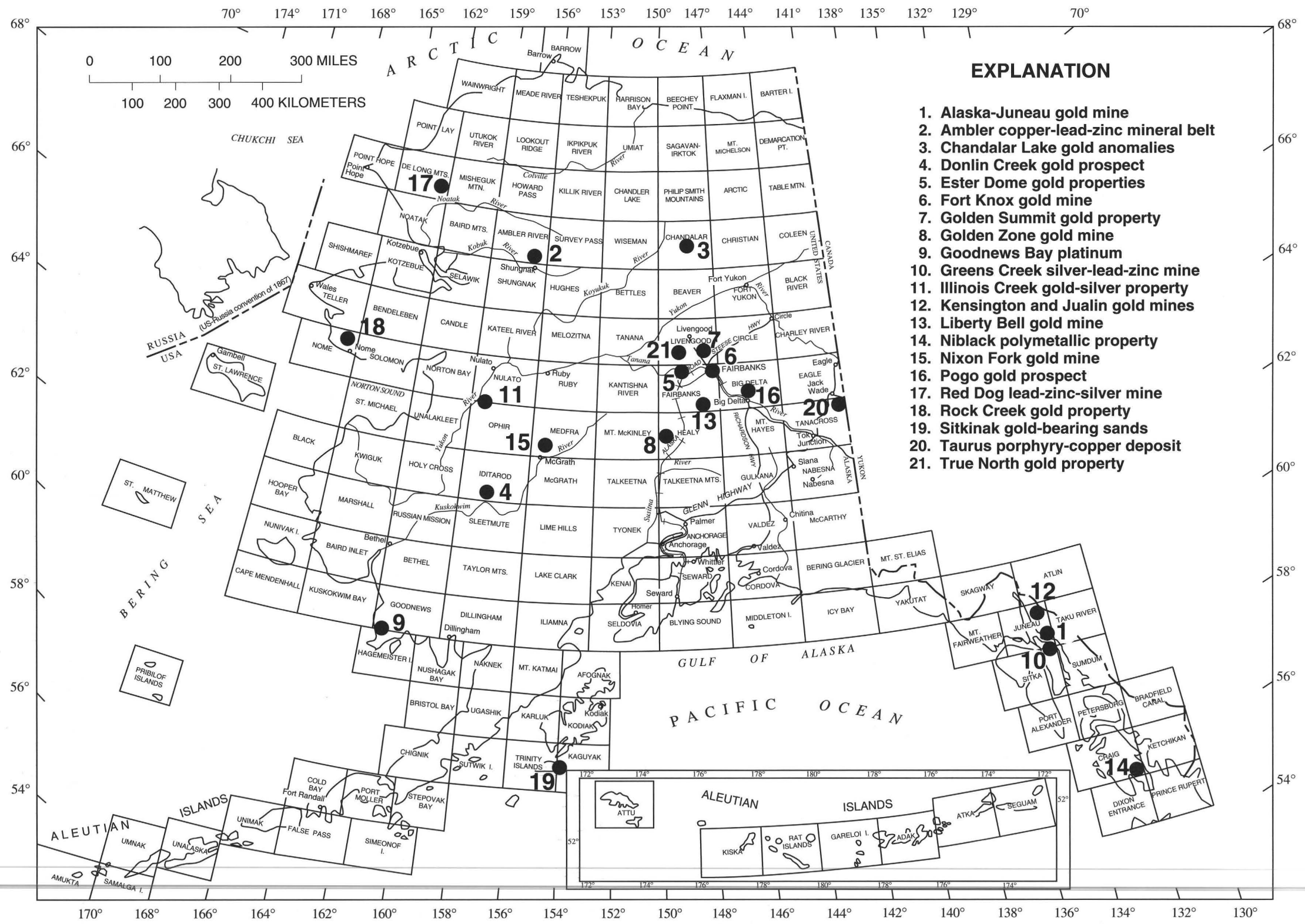

Figure 15. Locations of nonfuel metallic-mineral mines and deposits and areas of significant industry activity in 1996. 1:250,000-scale quadrangles and labeled. 
Incorporated, and ASA Incorporated prospected on Doyon lands adjacent to Nixon Fork, in the Seventymile district, and in the Rampart Mining District, respectively. Doyon Limited also contracted INAAlaska to explore 12,140 square kilometers of Doyon and Doyon-selected lands in the Coldfoot, Eagle/Fortymile, Flat, Tanana, and Wiseman areas; the multiyear agreement requires annual exploration expenditures of $\$ 1$ million.

\section{MINES AND PROSPECTS}

The following section describes major mineral activities made public by the mining industry in Alaska in 1996; there was also regional and site-specific exploration undocumented by published sources. The annual mining industry report published by the ADGGS (Swainbank and others, 1997) is a good source of information on mineral companies, mines, and production statistics.

\section{NORTHERN ALASKA}

Red Dog Mine.-The Red Dog polymetallic mine began production of lead-zinc-silver ore in 1990, becoming the world's largest zinc producer by 1994. Remaining reserves in the main open-pit deposit were estimated at 52 million metric tons of ore grading 19.5 percent zinc, 5.3 percent lead, and 100 grams of silver per metric ton. Just north of the mine, the Aqqaluk deposit was discovered in 1995, and delineation drilling was conducted in 1996. The Aqqaluk deposit was estimated to contain an inferred resource of 76 million metric tons of ore grading 13.7 percent zinc, 3.6 percent lead, and 66 grams of silver per metric ton. The Red Dog Mine is owned by NANA Regional Corporation and operated by Cominco Alaska.

DeLong Mountains Transportation System.-The AIDEA agreed to lend $\$ 85$ million to Cominco Alaska for enhancements to the DeLong Mountains Transportation System, which consists of the port, ore storage facility, and road that connects the Red Dog Mine to a port near Kivalina on Kotzebue Sound. Total project costs were estimated at $\$ 189$ million. Construction began in September 1996 and was scheduled for completion in 1998. The upgrades will allow the mine to expand production by 40 percent.

Ambler District.-The Ambler Mineral Belt contains the Arctic, Bornite, and Sun copper-lead-zinc massivesulfide deposits. Kennecott Exploration conducted a fixedwing geophysical survey of the belt in 1996 .

Eastern Brooks Range.-Far North leased a 50percent interest in 202 square kilometers of State mining claims in the Chandalar Lake area to Newcoast American and Footwall Explorations. The joint venture conducted rock and stream-sediment sampling, geologic mapping, geochemical sampling, and shallow drilling to explore and define several large gold anomalies on the property.

\section{WESTERN AND SOUTHWESTERN ALASKA}

Seward Peninsula.-Four mining companies continued work on the Seward Peninsula. Alaska Gold explored to expand reserves for its Cape Nome placer operation, and Nova Natural Resources tested a diver-assisted suction dredge on its offshore placer claims near Nome. Kennecott Exploration conducted drilling programs for lode gold at its Rock Creek and Mount Distin properties north of Nome. Cominco American explored for lode gold on Stateowned land near the Taylor Road and on Native lands northwest of Nome. Kennecott also completed an airborne geophysical survey of the Candle area on the eastern Seward Peninsula.

Illinois Creek Mine.-The Illinois Creek gold-silver property lies 400 kilometers west of Fairbanks near the Yukon River and contains reserves of 5 million metric tons of ore grading 2.5 grams of gold and 41 grams of silver per metric ton. The ore will be mined from an open pit, and the metals recovered from a zero-discharge heap-leach operation. In 1996, USMX of Alaska acquired ownership of Illinois Creek from North Pacific Mining, and ADNR issued permits for the mine's construction. The camp, office, and processing facility were built, and the first leach liner was laid; hydraulic testing of the liner was scheduled for May 1997, and production was anticipated by June. A limestone quarry at the mine provided low-grade rock for construction of the access road and will provide high-grade rock for production of quick-lime used in the leaching process.

Ophir District.-The Ophir District is located at the northern end of the Kuskokwim Mineral Belt, which parallels a series of intrusive centers stretching from Bethel to Medfra. Gold mineralization in the belt is disseminated with sulfides and also exists in stockwork veining associated with granite porphyry dikes. USMX Incorporated conducted an exploration program on AMHT lands in the Ophir District. Historic production from placers in the Ophir area was 18,700 kilograms of gold.

Nixon Fork Mine.-The Nixon Fork gold mine, operated by Consolidated Nevada Goldfields Corporation, was the largest gold mine in Alaska in 1996, producing 1,197 kilograms of gold and 160 metric tons of byproduct copper. Exploration at the mine increased reserves to 4,789 kilograms of gold. In addition, disseminated gold ore was discovered in the interior of the Nixon Fork intrusion, and gold-skarn mineralized rocks were identified adjacent to the intrusion.

Donlin Creek.-Placer Dome U.S. continued its exploration program at the Donlin Creek gold prospect, spending \$9.67 million in 1996 for a camp, airstrip, and 40,450 meters of hardrock core from 109 drill holes. Mineralized rock occurs in seven discrete deposits, and 
combined reserves from two of the deposits total 111,970 kilograms of gold. Ventures Resource Corporation staked the Donlin North property, a 36-square-kilometer parcel along the projected mineralized trend of the Donlin Creek deposit.

Goodnews Bay.-Goodnews Bay was the largest platinum producer in the United States until placer reserves ran out in 1975. In 1996, Alaska Earth Sciences and Corral Creek Corporation prospected on Calista Corporation lands for the lode source of the platinum.

\section{FAIRBANKS MINING DISTRICT}

The ADGGS released an aeromagnetic map of the Fairbanks Mining District in early 1995 that showed numerous strong magnetic anomalies trending southwestnortheast through the district (Alaska Division of Geological and Geophysical Surveys, Dighem, and WGM, 1995). Because some of the anomalies occurred over known mineral deposits, other anomalies were investigated for possible similar associations. Claim staking and regional exploration occurred in 1995, and site-specific programs focused on identified targets in 1996.

Twin Buttes/Juniper Creek.-La Teko Resources signed a 5-year lease agreement with the University of Alaska to explore the Twin Buttes property, 48 kilometers northeast of Fairbanks. Geochemical sampling was conducted on the prospect and on La Teko's adjacent Juniper Creek property, where ore has been found grading 8.5 grams of gold per metric ton.

True North.-Newmont Exploration explored La Teko's True North gold property, located 24 kilometers north of Fairbanks. The gold is associated with quartz-carbonate veins in metamorphic rocks, and La Teko has estimated the resource at more than 62,000 kilograms of gold. Hardrock core drilling was performed to determine continuity and limits of mineralized rock; geochemical prospecting was conducted outside the known deposit area. Homestake Mining agreed to purchase from Silverado Mines the Whiskey Gulch and Marshall Dome properties, which cover 59 square kilometers adjacent to True North.

Fort Knox Mine.-Amax Gold Incorporated completed construction of its Fort Knox Mine, 24 kilometers northeast of Fairbanks. Production was initiated in November 1996, and three 22-kilogram gold bars were poured in late December. The deposit contains proven and probable reserves of more than 127,500 kilograms of gold, and recent drilling results indicated an additional possible resource of 84,000 kilograms of gold; the gold is disseminated within igneous rocks. The mine has a projected life of 12 years.

Fish Creek.-Flame Petro-Minerals Corporation began drilling on their Fish Creek claims, which are adjacent to the Fort Knox deposit. Several 30-meter holes were drilled to explore specific targets; core samples were similar in geology to rocks of the Fort Knox deposit, and some contained visible gold.

Golden Summit.-International Freegold Development continued exploration at its Golden Summit property, which lies between the Fort Knox and True North properties and contains both vein and disseminated gold in 84 known lode occurrences. Drilling at the Dolphin Zone identified mineralized rocks over a strike length of almost 2 kilometers, and a preliminary estimate indicated resources of 9,000 kilograms of disseminated gold. At the Too Much Gold prospect, trenching and soil sampling outlined a 1.3kilometer-long zone of mineralized veins. Reconnaissance mapping and sampling were conducted on the Wolf Creek and Pilot Creek prospects. Exploration drilling was initiated at the Cleary Hill Mine, the district's largest past-producing underground mine.

Ester Dome.-The Ester Dome gold project is located approximately 10 kilometers west of Fairbanks and encompasses 52 square kilometers. Silverado Mines conducted trenching and drilling at the St. Paul, Rhyolite, and other prospects on the property.

Cripple Creek.-Exploration Orbite and Yellow Eagle Mining began production in June at their Cripple Creek gold placer near Ester. The partners expected to yield approximately 118 kilograms of gold per month, operating on a seasonal basis.

\section{EAST-CENTRAL ALASKA}

Stone Boy venture.-WGM Incorporated, Sumitomo Metal Mining Canada, and the Metal Mining Agency of Japan formed the Stone Boy joint venture in 1991 to explore 12 gold properties northeast of Delta Junction. After a regional reconnaissance program, exploration focused on the Pogo prospect, which encompasses 750 State mining claims and has a defined gold-in-soil anomaly measuring 1.2 kilometers by 1.8 kilometers. In 1996, WGM drilled 17 holes totaling 6,100 meters in the flat-lying, highgrade deposit.

Liberty Bell Mine.-Pacific Northwest Resources drilled the Liberty Bell gold-arsenic-copper deposit near Healy; reserves have been estimated at 1 million metric tons containing 3,560 kilograms of gold. Historic production from the underground mine was reported at 261 kilograms of gold from 15,900 metric tons of ore.

Other-Cyprus-Amax, Kennecott Exploration, and others staked claims around Tri-Valley's gold-silver property in the Richardson district west of Delta. American Copper and Nickel conducted geophysical and geochemical surveys at its Nikolai copper-nickel prospect south of Delta Junction; the company also conducted geophysical surveys and drilled 4,300 meters of core in the Delta Belt polymetallic district southwest of Tok. Reliance Geological Services conducted 
geochemical and geophysical surveys and a drill program on the Taurus porphyry copper-gold prospect north of Tok.

\section{SOUTH-CENTRAL ALASKA}

Golden Zone Mine.-The Golden Zone Mine produced gold for a short period in 1941 but shut down at the onset of World War II. Proven and probable reserves are currently estimated at 18,662 kilograms of gold with copper and silver by-products; potential reserves could yield up to 62,000 kilograms of gold. Airborne geophysics and a drilling program were conducted in 1996. The mine is located 421 kilometers north of Anchorage and is owned by the Mines Trust Company, which is developing the mine in partnership with Addwest Minerals and the Hawley Resource Group.

Gold-bearing sands.-Leader Mining International and Nugold Technology announced a program to sample, bulk test, and calculate reserves for gold-bearing beach sands on Sitkinak Island south of Kodiak. If results were favorable, they hoped to start production by 1997.

\section{SOUTHEASTERN ALASKA}

Kensington gold project.-The Kensington property is located in the Berners Bay Mining District at the northern end of the Juneau Gold Belt; calculated reserves total 60,650 kilograms of gold. Coeur Alaska acquired full ownership and operating interest in the property in 1995 and, after soliciting input on local environmental and fishing concerns, proposed changes in 1996 to the project's construction, operation, closure, reclamation, and overall environmental design. One major change would eliminate the need for large quantities of cyanide and chlorine at the mill by shipping the ore concentrate off-site for final gold recovery. Another major change would eliminate dam, tailings pond, and stream diversion by removing and recycling water from mine tailings and using a dry tailings disposal methodology: some dry tailings would be disposed underground, and the remainder used above ground for site reclamation. The FS, EPA, and ACE are cooperating in the preparation of a Supplemental EIS to address all proposed changes to the previously approved Plan of Operations.

Jualin gold prospect.-In 1996, Coeur Alaska and Hyak Mining conducted mostly maintenance operations at the Jualin gold prospect, 4 kilometers southeast of the Kensington property. Some limited surface exploration was conducted, but most operations were on hold pending approval of the Kensington project. Gold reserve estimates remained at 12,400 kilograms.

Alaska-Juneau Mine.-In response to an EPA review of its mining plan, Echo Bay Alaska began to redesign its ore recovery and tailings disposal plans for the Alaska-Juneau (A-J) gold mine in the State's capital city. However, after failing in 1994 to obtain the final permits necessary to reopen the mine, Echo Bay announced in early 1997 that the project was no longer economically viable in its planned form. Total costs for the operation would have reached $\$ 300$ million, with anticipated production of 9.3 million grams of gold per year. The company decided to either close down the project indefinitely or sell the property.

Greens Creek Mine.-After a 3-year shutdown, the Greens Creek Mine reopened in 1996. In the interim, reserve estimates were increased to 7.9 million metric tons of ore grading 660 grams of silver per ton, 5.5 grams of gold per ton, 4.8 percent lead, and 13.1 percent zinc; operations were streamlined; and metal prices had improved. During the hiatus, Kennecott Greens Creek Mining Company spent $\$ 88$ million for capital improvements, new equipment, improved water-treatment facilities, and 6.1 kilometers of new tunnels to reach the southwestern ore body. The mill was refurbished, and a gravity circuit for precious-metal recovery was added. Milling started in July, and the first concentrates were sent out in November. Annual production was expected to reach 342,000 kilograms of silver, 1,900 kilograms of gold, 36,290 metric tons of zinc, 18,144 metric tons of lead, and byproduct copper. The Greens Creek Exchange Act became law in 1996, allowing underground access to lands adjacent to the mine's patented claims, in return for royalty payments and land transfers by the mining company to the Federal government.

Niblack project.-Abacus Minerals conducted a drilling program at the Niblack polymetallic property, which is on Federal patented and unpatented claims on southern Prince of Wales Island. Drilling on the Lookout zone intersected up to three massive-sulfide horizons over a strike length of 275 meters; reserves were estimated at 1.63 million metric tons of ore grading 4.1 grams of gold per ton, 46.9 grams of silver per ton, 1.5 percent copper, and 2.64 percent zinc.

Mansfield Peninsula.-Westmin Resources and Kennecott Exploration each conducted exploration programs on the Mansfield Peninsula of Admiralty Island. Alaska Dano conducted surface exploration on their patented claims in the same area.

\section{ACTIVITY BY FEDERAL AGENCIES}

\section{INTERAGENCY MINERALS COORDINATING GROUP}

An Interagency Minerals Coordinating Group (IMCG), composed of personnel from the BLM, USGS, FS, and ADGGS, began meeting in March 1996. A memorandum on increasing cooperation and coordination of mineral activities in Alaska was signed by these agencies in May 1996. One of the group's goals was to develop a statewide plan for coordinated mineral-resource assessments 
and related activities. A draft 5-year plan was completed and presented to several user organizations for review.

Another goal of the IMCG was to develop a digital index of geologic information on Alaska. The IMCG produced a working prototype of an Internet-accessible bibliographic data base, which was demonstrated at the Alaska Miners Association Annual Convention and Trade Fair in November. The data base was expected to be enhanced and made available on the WorldWide Web during 1997 at http://imcg.wr.usgs.gov/.

\section{U.S. GEOLOGICAL SURVEY}

\section{MINERAL-RESOURCE ASSESSMENTS}

Much of the USGS Alaska program was conducted to implement the Alaska Mineral Resource Assessment Program (AMRAP) defined in Section 1010 of ANILCA, which requires the assessment of "mineral potential on all public lands in the State of Alaska." Assessments done under AMRAP employ field mapping, geochemical analyses, geophysical studies, and mineral-deposit modeling to define districts of potential mineral resources. The scope of AMRAP studies varies from Statewide projects to investigations of individual mineral deposits. Geologic and mineral-resource activities in Alaska at the regional, quadrangle-scale, and topical levels are shown on figures 16 and 17 and table 10 .

Statewide.-The Statewide Alaska Mineral Resource Assessment project (SAMRAP) was initiated in 1993 to (1) prepare maps, accompanied by tables of important deposits, showing permissive mineral-resource assessment tracts; and (2) prepare quantitative estimates of the undiscovered resources of copper, lead, zinc, gold, and silver in selected mineral-deposit types. The draft report was completed in 1996, and, following comprehensive review, final publication of SAMRAP will be in digital format.

Adjunct to this project was the compilation of the Alaska Resource Data File (ARDF), a 4,428-record data base of information on the lode and placer deposits of Alaska. A guide to terminology used in the ARDF was published (U.S. Geological Survey, 1996), and ARDF compilations were completed for the Adak (Wilson and Light, 1996), Demarcation Point (Kelley, 1997a), Holy Cross (Keith and Miller, 1996a), Iditarod (Keith and Miller, 1996b), Mount Michelson (Kelley, 1997b), Umiat (Kelley, 1997c), and Unalaska (Wilson, 1996) quadrangles; these reports are also available on the WorldWide Web at http://www-mrsak.wr.usgs.gov/ardf.

Regional.-Regional studies address large areas of the State, and resultant maps are generally published at a scale of $1: 500,000$ to $1: 1,000,000$. In 1996, assessment studies were underway for the Alaska Peninsula, eastern Alaska Range, Kuskokwim mineral belt, and Sitka area.
Table 10. USGS regional and topical studies in 1996.

[Asterisk indicates statewide project; other locations shown on figure 16]

Regional mineral-resource assessments

Alaska Peninsula--geology and mineral resources

Eastern Alaska Range--metallogenesis

Fortymile Mining District--placer gold deposits

Kuskokwim Mineral Belt--lode gold deposits

Sitka transect--geology and mineral resources

\begin{tabular}{l|}
\hline \multicolumn{1}{c||}{ Mineral deposit studies } \\
\hline Donlin Creek porphyry gold deposit \\
Greens Creek lead-zinc-silver massive-sulfide deposit \\
Juneau Gold Belt--lode gold deposits \\
Red Dog zinc-lead-silver massive-sulfide deposit \\
Southern Alaska gold veins--tectonic setting \\
Stuyahok River-Flat Creek mineral resources \\
\hline Framework or process studies
\end{tabular}

*Alaska--regional metamorphic-facies maps

East-central Alaska--syngenetic massive-sulfide deposits

Howard Pass--geologic map

Interior Alaska--geophysical data

Norton Bay-Unalakleet--geology and mineral resources

Rampart Mining District--geologic mapping

\begin{tabular}{l}
\hline \multicolumn{1}{c||}{ Regional geochemical studies } \\
\hline $\begin{array}{l}\text { Admiralty Island--geochemistry } \\
\text { Southwestern Alaska--epithermal mercury deposits }\end{array}$ \\
\hline Environmental geochemical studies \\
\hline Brooks Range--exhalative Zn-Pb-Ag deposits \\
Prince William Sound--massive-sulfide deposits \\
Southwestern Alaska--mercury deposits \\
Wrangell-St. Elias NP\&P--active and abandoned mine \\
lands
\end{tabular}

Fieldwork began on a study to characterize the geology and metallogeny of stratiform massive-sulfide deposits of eastcentral Alaska. Descriptions of mineral-resource-assessment tracts in southeastern Alaska were revised (Brew and others, 1996), and framework studies were published on the stratigraphy of the Alaska Peninsula (Detterman and others, 1996) and on the metamorphic rocks of southeastern and southwestern Alaska (Dusel-Bacon, Brew, and Douglass, 1996; Dusel-Bacon, Doyle, and Box, 1996).

A cooperative project between the USGS and the Alaska Division of Oil and Gas resulted in the compilation of aeromagnetic and gravity data for 25 quadrangles in 


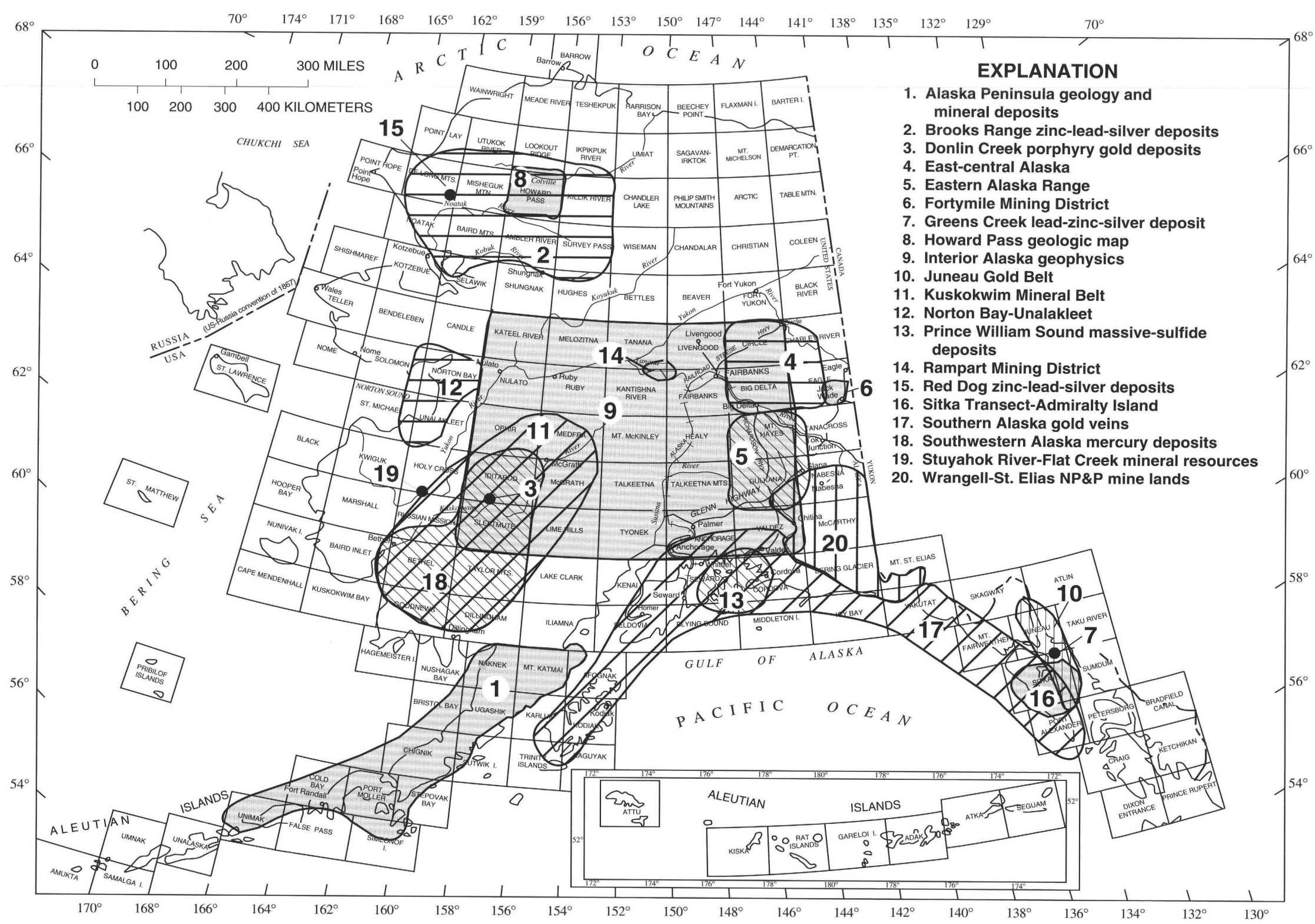

Figure 16. Locations of 1996 USGS regional and topical studies listed in table. 1:250,000 scale guadrangles are outlined and labeled. 


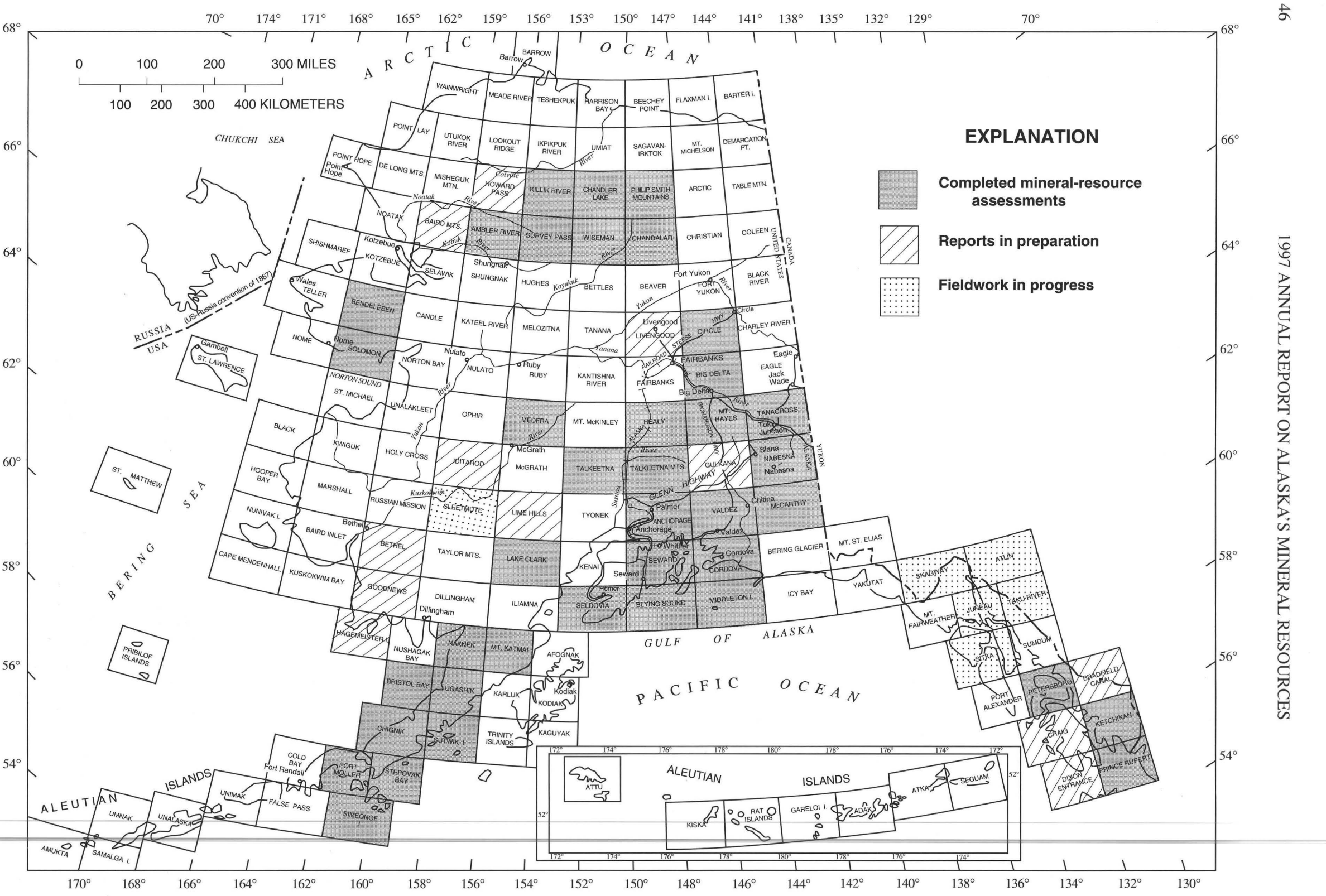

Figure 17. Status of USGS AMRAP quadrangle studies as of January 1997. 1:250,000-scale quadrangles are outlined and labeled. 
Interior Alaska; resultant maps were published at a scale of 1:500,000 (Meyer and Saltus, 1995; Meyer and others, 1996). The maps will be used for geologic framework studies (Saltus and others, 1997) and for regional mineraland energy-resource evaluations. The digital data from these compilations are available to the public from the National Geophysical Data Center, 325 Broadway, Boulder, CO 80303-3328.

Quadrangles.-Mineral-resource assessments of 1:250,000-scale quadrangles (fig. 17) have been the core of AMRAP for many years, complementing and supporting both regional and site-specific studies. Each multidisciplinary project has produced geologic, geochemical, and geophysical maps; mineral deposit and mineral-resource assessment maps; a table of mineral deposit descriptions; and a summary publication. By the end of 1996, 39 AMRAP quadrangles had been completed. In 1996, geologic maps were published for the Killik River quadrangle (Mull and others, 1996) and for the Craig and Dixon Entrance quadrangles (Brew, 1996). Resource assessments were published for the Chandler Lake quadrangle (Church, Kelley, and Bohn, 1996), the Survey Pass quadrangle (Grybeck and others, 1996), and the Port Moller, Stepovak Bay, and Simeonof Island quadrangles (Wilson and others, 1996). A gravity map was published for the Bethel quadrangle (Morin, 1996), and geochemical data were published for the Howard Pass quadrangle (Kelley and others, 1996).

Topical studies.-Topical studies consist of areal mineral-resource assessments, framework or process studies, and regional geochemistry; projects incorporate detailed mapping (1:63,360 or larger scale), sampling of individual mineral deposits or mining districts, and related field and laboratory research. Ongoing topical studies in Alaska are listed in table 10. Published reports included tectonic setting of southern Alaska gold deposits (Haeussler and Bradley, 1996), ages of lode gold deposits in the Nome District (Ford and Snee, 1996), and descriptions of the Pyramid porphyry copper (White and others, 1996) and Shumagin gold (White and Queen, 1996) deposits on the Alaska Peninsula. The Fortymile Mining District study (Yeend, 1996) included bedrock geology; geology, mineralogy, and genesis of the placer gold deposits; current mining operations; and a history of mining in the district.

Research summaries.-The USGS compiles an annual research report on USGS studies in Alaska. The volume on investigations carried out in 1994 has been published (Moore and Dumoulin, 1996); mineral-resource studies in this publication covered organic matter in rocks near Nixon Fork (Jacobson, Blodgett, and Babcock, 1996), the Bokan Mountain rare-earth deposit (Philpotts, Taylor, and Baedecker, 1996), environmental geochemistry of three mining districts (Kelley and Taylor, 1996; Gray and others, 1996; Trainor and others, 1996), and acid mine drainage in
Prince William Sound (Goldfarb and others, 1996).

The report on 1995 studies was also compiled (Dumoulin and Gray, 1997). Metallic-mineral resource studies in this volume include reports on silver-lead-zinc mineralization in the Howard Pass quadrangle (Kelley, Taylor, and Cieutat, 1997), newly discovered mineral occurrences in southwestern Alaska (Gray and Theodorakos, 1997), and molybdenum mineralization in the Taku River region of southeastern Alaska (Miller and others, 1997). Environmental studies related to Alaska mineral deposits include hydrogeochemistry of mine-drainage waters associated with low-sulfide gold-quartz veins (Goldfarb and others, 1997), environmental geochemistry of the Nabesna gold skarn and Kennecott stratabound copper deposits (Eppinger, Sutley, and McHugh, 1997) and of mercury in the Kuskokwim Mountains region of southwestern Alaska (Bailey and Gray, 1997), and trace-element sources in Denali National Park and Preserve (NP\&P) (Gough and Crock, 1997). Rocks containing lead-zinc-barite deposits in the Brooks Range are described (Dumoulin and Harris, 1997; Mull, Harris, and Carter, 1997). Two bibliographies of publications on Alaska by USGS authors are also included (Galloway and Toussaint, 1997a, 1997b).

\section{ENVIRONMENTAL STUDIES}

In recent years, the USGS initiated a program to study the environmental effects of elements and metals associated with mineral deposits, especially where these elements or metals may be toxic to humans or wildlife. In 1996, USGS personnel collected samples of soils, vegetation, stream sediments, stream waters, and fish at three abandoned mercury mines in southwestern Alaska; the research will study the occurrence and spatial distribution of the different chemical species of mercury at the mine sites, as well as the processes that control the distribution of mercury in the terrestrial and aquatic environments. In southeastern Alaska, geochemical samples were collected to determine the acidity and composition of waters in abandoned and active mines and to analyze the effects that these waters have on the surrounding ecosystems (fig. 18).

Knowing the baseline geochemistry of a mineralized area allows for better planning of mining and mitigation activities and for the assessment of undiscovered mineral deposits. USGS work in Wrangell-St.Elias NP\&P will characterize baseline geochemistry in unmined areas with active mineral claims and will evaluate environmental contamination from active and abandoned mines for remediation measures.

A report was released in 1996 that (1) included a discussion of the geochemical processes by which metals enter environments downstream from mineral deposits and (2) summarized studies of natural and manmade environmental interactions of selected mineral deposits in 


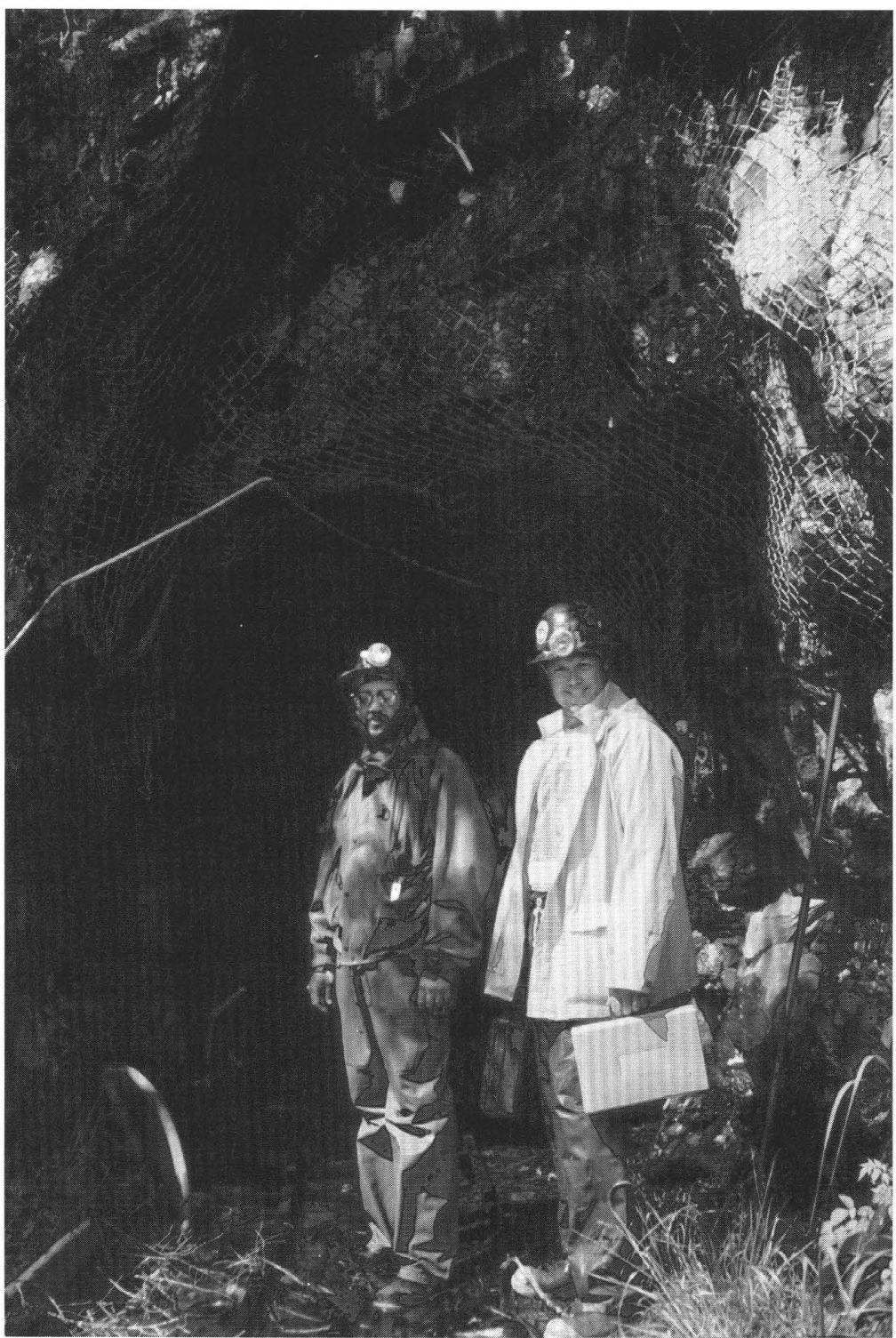

Figure 18. USGS geologists prepare to sample mine waters at the Golden Gate adit of the abandoned Hirst-Chichagof Mine on Chichagof Island in southeastern Alaska. The work is part of a study to investigate the effects that mine-drainage waters have on the surrounding ecosystems. Photograph by S. Karl, USGS.

Alaska (Gray and Sanzolone, 1996). Topics included the natural environmental effects of heavy-metal massivesulfide deposits in the northwestern Brooks Range and in Prince William Sound; environmental geochemistry of mercury mines in southwestern Alaska, of lode gold deposits in the Pacific Gulf Coast, of placer gold deposits in the Fairbanks and Nome Mining Districts, and of Alaska chromite deposits; and radioactivity concerns of uranium and thorium deposits at Bokan Mountain in southeastern Alaska.
COOPERATIVE WORK WITH FEDERAL AGENCIES

National Park Service.-The USGS and NPS have a cooperative project in Wrangell-St. Elias NP\&P to evaluate the environmental geochemistry of mineral deposits and mines within the park, in order to provide NPS land managers with premining and current baseline information to be used in the decision-making process. In unmined areas with active mineral claims, baseline geochemical data provides a framework for planning any 
mining activities that may occur. At active or abandoned mine sites, any mining-induced contamination and its areal extent can be identified for remediation purposes. USGS and NPS personnel collected samples of rock, sediment, water, mill tailings, and mine drainage at the Kennecott (frontispiece), Nabesna, Orange Hill, Gold Hill, and Bremner District Mines and deposits for analysis and interpretation.

Forest Service.-In the Hoonah ranger district of the Tongass National Forest, the USGS developed an Interagency Agreement with the FS to provide geologic expertise in several areas: a geologic base map (Karl, 1996) for the FS ecosystem study of the Northeast Chichagof area; an assessment of limestone resources as construction material and for use in mitigation of acid mine drainage; and a study of the surficial and glacial geology of southeastern Alaska, to help the FS deal more effectively with landslides in their road-building operations. In the Juneau ranger district, reconnaissance mapping in the Coast Mountains near Skagway was performed to assess the area's general mineralresource environment.

COOPERATIVE WORK WITH THE STATE OF ALASKA

The USGS also contributes its expertise to projects conducted by the ADGGS. A study of the Rampart-ManleyTofty area, located northwest of Fairbanks, is the most recent in a series of high-priority mining district studies carried out by the ADGGS. USGS scientists participated in geologic mapping, data interpretation, and report production for the project. Results of the airborne geophysical survey have been released (Alaska Division of Geological and Geophysical Surveys, Dighem, and WGM, 1996a, 1996b, 1996c, 1996d).

\section{COOPERATIVE WORK WITH ALASKA NATIVE CORPORATIONS}

The USGS had a cooperative research and development agreement with the Calista Native regional corporation to perform geologic mapping and geochemical sampling in the Stuyahok River-Flat Creek area of the Holy Cross quadrangle in southwestern Alaska, for the purpose of assessing the mineral resources in the area. Gold has been mined from area placer deposits, and rocks favorable for lode gold, tungsten, and mercury deposits are present. USGS and Calista personnel performed the fieldwork in 1995, and Calista provided additional proprietary geochemical data. The USGS published a geologic map and summary mineral-resource assessment (Miller and others, 1996) and geochemical data for rock samples (Keith and others, 1996) and soil, sediment, and water samples (Bailey and others, 1996). The Stuyahok project work will be integrated into a larger study of the Kuskokwim Mineral Belt.
COOPERATIVE WORK WITH FOREIGN SCIENTIFIC AGENCIES

The USGS collaborated with Russian, Canadian, and Alaska State geologists to evaluate the mineral resources of the Russian Far East and to develop an integrated metallogenic model for the Russian Far East, Alaska, and western Canada; in addition to maps and tables, digital data bases of mineral deposits and mining districts in the three areas were compiled. Detailed summaries and data for 1,079 lode deposits and 158 placer districts in the region were published (Nokleberg and others, 1996).

\section{BUREAU OF LAND MANAGEMENT}

MINING CLAIM MANAGEMENT

Recorded claims.-In 1996, the number of new Federal mining claims in Alaska increased sixfold, but total mining claims decreased: the BLM recorded 952 new claims and 9,642 total claims, in contrast to the 162 new claims and 9,705 total claims in 1995 . One mineral patent was issued for 58 claims covering 4 square kilometers, and 2 patent applications were withdrawn. The number of Federal mining claims in Alaska has declined annually since 1993.

Mining operations.-The BLM oversees mine development, production, and reclamation on BLMmanaged estate. Mining Plans of Operations are required for mining activities covering an area greater than 0.02 square kilometers, and Notices of Intent are required for areas less than or equal to 0.02 square kilometers. In 1996, the BLM processed 64 Plans and 131 Notices and completed 353 surface compliance inspections for mining operations throughout the State. Two of the compliance inspections were conducted at the Nixon Fork Mine in southwestern Alaska, the largest gold producer in Alaska on Federal mining claims and the first lode mine to come into production since the 1930's. Because the mine is on BLM lands, the BLM is responsible for operator compliance to the permitted Plan of Operations. To fulfill this obligation, the BLM conducted the on-site inspections and used aerial photography to document the surface impact of the operation. In east-central Alaska, the Valdez Creek Mine, North America's largest placer mine, ceased production in late 1995, and reclamation was completed in October 1996; Cambior Alaska, the mine's owner, was honored by the State and the BLM, jointly, for its reclamation work.

Mineral examinations.-The BLM has adjudication and review authority for all mineral validity and patent exams on Federal lands (fig. 19). In 1996, field 


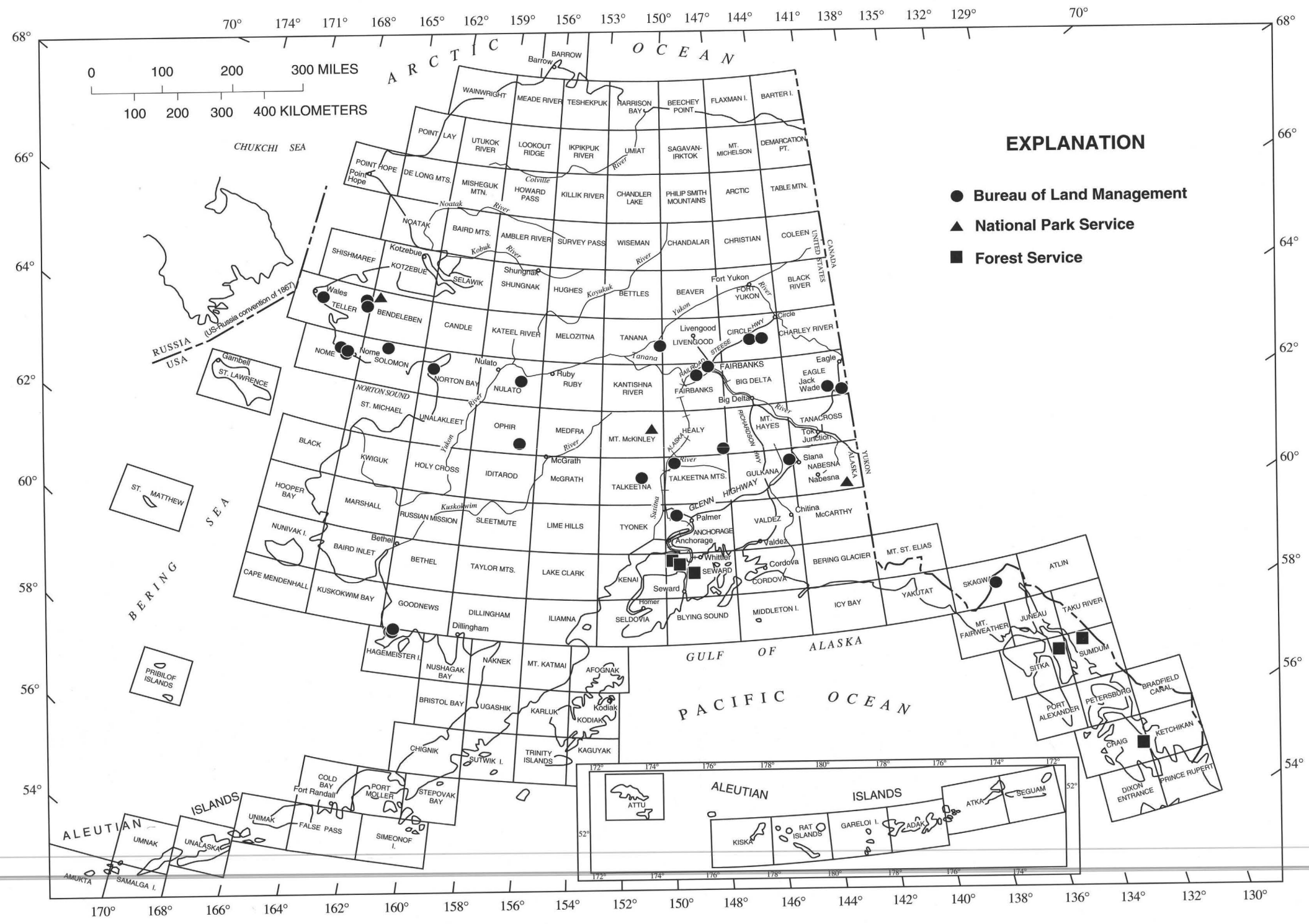

Figure 19. Locations of 1996 active Federal mineral patent case files. 1:250,000-scale quadrangles are outlined and labeled. 
examinations were conducted for four mineral patent applications. The BLM also reviewed four BLM mineral reports, two NPS mineral reports, and two FS mineral reports, and completed 103 mineral reports in support of Land Use Plans such as land conveyances or Recreation and Public Purpose Leases. The BLM is under legislative mandate to process, before October 1999, all mineral patent applications that had been submitted to the DOI before November 1995; this includes adjudication, field exams, and writing and review of the mineral reports.

Reclamation.-To ensure reclamation of mined lands, bonding is required for all mining Plans of Operations on Federal mining claims. Bonding for Notices is not required at this time, except if the operator has a history of noncompliance, in which case bonding for the calculated reclamation costs would be required. The BLM administers these bonding requirements for mining operations on BLM-managed lands. In 1996, a Memorandum of Understanding between the State of Alaska and the BLM was completed that would allow access to the State bonding pool by mining operators on Federal claims; if approved, the memorandum was scheduled to go into effect in March 1997.

The BLM Reclamation Standards working group identified two major activities critical to reclamation: cataloging and prioritizing watersheds, and monitoring the reclamation process to evaluate the outcome. Pilot projects were initiated to evaluate specific reclamation methods and vegetation requirements. In April 1997, the working group was expected to publish a draft reclamation handbook that would be finalized in late 1997 after the results of summer field studies were known.

Mining claim use and occupancy.-The BLM finalized its Use and Occupancy regulations in September 1996 [43 CFR 3715]. Under the new regulations, residences on all Federal mining claims are to be included in an environmental assessment; formerly, only Plans of Operations were required to meet the criteria of the National Environmental Policy Act. Residence on a mining claim must be reasonably incident to mining or exploration, and any residence not reasonably incident will be required to be removed. An occupant failing to meet these regulatory requirements can incur civil and/or criminal penalties. BLM mineral examiners are to conduct surface-use examinations on occupancies to determine if they are legitimately incidental to mining or exploration.

Abandoned mine lands.-The BLM continued to inventory abandoned mine lands (AML) in Alaska. Efforts were focused on literature searches in the MAS and MILS data bases and in existing mineral case files. Potential AML sites will be investigated as part of the BLM surfacemanagement program, using guidelines from the BLM Alaska AML Strategy and the BLM national database field checklist and data dictionary. The Department of Defense's Global Positioning System (GPS) will also be used to identify and map sites.

COOPERATIVE WORK WITH THE FOREST SERVICE

Sitka and Hoonah Ranger Districts.-The BLM continued the systematic evaluation of mines, prospects, and mineral occurrences in the Sitka and Hoonah Ranger Districts, which the former USBM had initiated in 1994. Additional field studies were conducted in 1996, and a progress report was released (Maas, Bittenbender, and Still, 1996).

Stikine Area.-The BLM performed a reconnaissance of the Stikine Area in 1996 in order to define the work required to perform a mineral assessment of the area, which includes the Petersburg and Kupreanof Mining Districts. A 3-year study of the Stikine Area was scheduled to begin in 1997.

Abandoned-mine land inventory.-The BLM continued the USBM project to evaluate abandoned and inactive mine sites in the Tongass National Forest (fig. 20). The MAS data base was used to develop a prioritized list of abandoned mine sites. In the Chatham Area, 50 high-priority sites were mapped and sampled for physical and environmental hazards in 1995; an additional 55 sites were evaluated in the Ketchikan and Stikine Areas during 1996.

\section{OTHER ACTIVITIES}

In 1996, the BLM completed the final season of fieldwork for its geologic guide to the Taylor Highway and Fortymile Wild and Scenic River area; during final field check, geologists described new outcrops created by road construction on the Taylor Highway. In addition to rock types and mineral occurrences seen in roadside and riverside outcrops, the guide describes the general geologic history of the area and relates the history of the Fortymile Mining District from early gold mining days to present status and land disposition. Target date for publication was the Klondike Centennial in 1997.

Public outreach remained an important component of the BLM minerals program. A bibliography of all USBM publications for Alaska was released (Bureau of Land Management, 1996). Geologists and mining engineers staffed the annual Outdoor Week programs of the Anchorage and Fairbanks school districts and gave classroom presentations on rocks, minerals, and fossils throughout the year. The BLM continued its work with the Anchorage School District to develop an improved earth-science curriculum by providing teachers with technical expertise on minerals activities and on the 


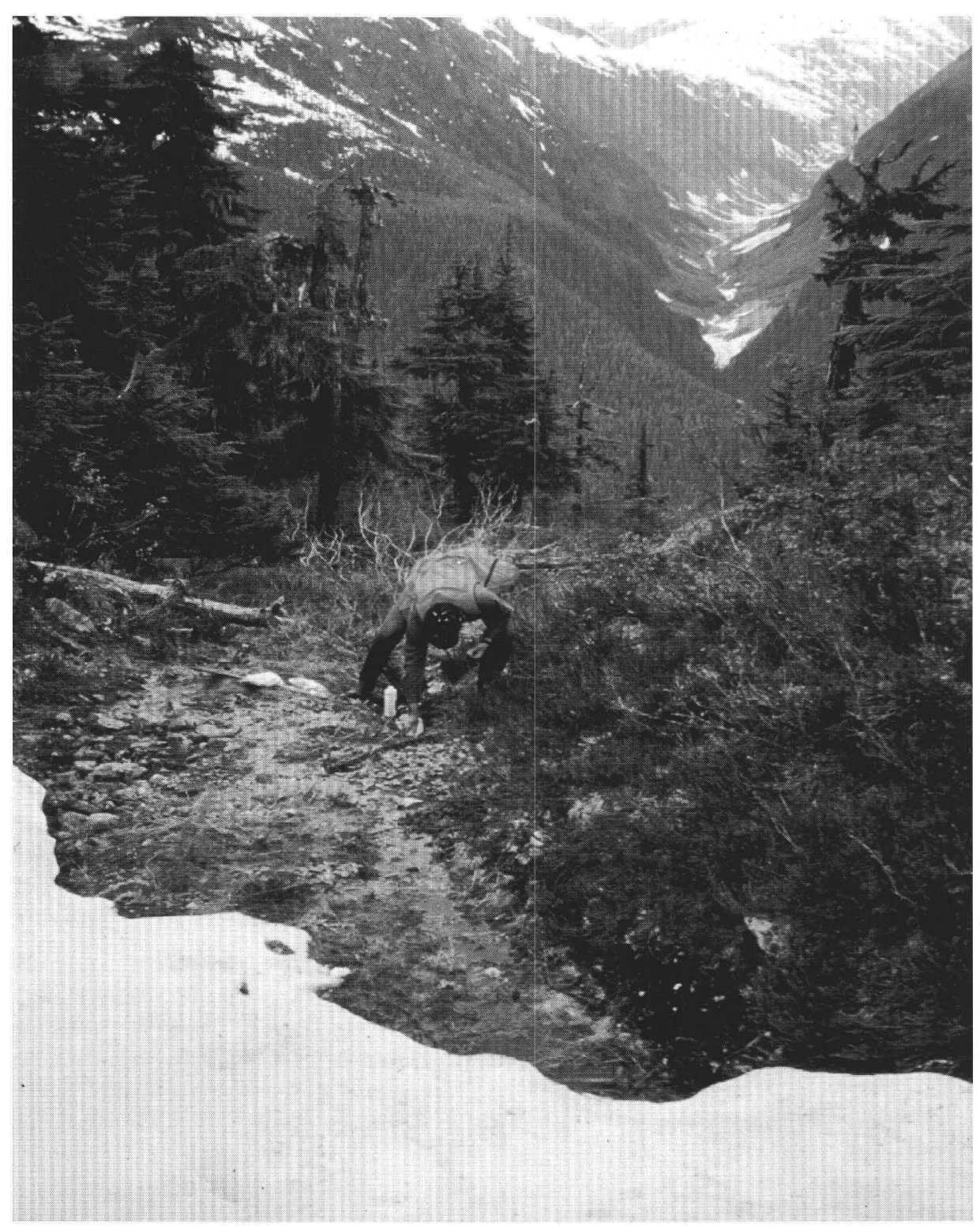

Figure 20. BLM geologist collects a water sample below the abandoned Ronan Mine, north of Hyder in southeastern Alaska. This work is part of a cooperative project with the FS to evaluate abandoned and inactive mine sites in the Tongass National Forest. Photograph from BLM files.

contribution of earth sciences to viable ecosystem management practices.

The Campbell Creek Science Center at the BLM's Campbell Tract in Anchorage was dedicated in November 1996. The center is a cooperative venture between State and Federal agencies, private concerns, industry, and the Anchorage School District to further scientific education in the community. The facility is adjacent to undeveloped lands where the natural processes of the Anchorage Bowl's sub-Arctic environment are available for studies. The curriculum will balance minerals activities and an environmentally aware scope of ecosystem management.

\section{NATIONAL PARK SERVICE}

MINERAL LANDS MANAGEMENT

Mining Plans of Operations.--In Denali NP\&P, six mining Plans of Operations were received in 1996. Two of these Plans, plus one Plan received in 1995, were reviewed and determined to be incomplete; one Plan was reviewed and denied. Appeals were filed for the denied Plan and one of the incomplete Plans. The three remaining Plans received in 1996 remained in review status, as did another 1995 Plan. In Wrangell-St. Elias NP\&P, the 
components of one Plan were informally reviewed by park staff. No mining Plans of Operations were approved by the NPS during 1996. Only two mining operations were under permit in Alaska units during 1996, but no activity took place at the claims in Bering Land Bridge National Preserve, and only a low level of activity occurred in Wrangell-St. Elias NP\&P. Both permits expired at the end of the 1996 field season.

Mineral validity examinations.-As of April 1996, there were 770 administratively valid, unpatented Federal mining claims in Alaska park units. Determination of the mineral-resource validity of these mining claims is a necessary component of mining Plan review and claim acquisition. NPS mineral examiners are certified by the BLM, and the BLM has final approval authority for NPS mineral validity examinations. In 1996, NPS mineral examiners investigated six mining claims in Denali NP\&P and one claim in Wrangell-St.Elias NP\&P; mineral reports for these claims were expected to be completed by 1998 . The BLM approved two NPS mineral reports on five claims within Denali NP\&P and reviewed an additional report on eight claims in Denali NP\&P.

Mining claim acquisition.-Since 1991, the NPS has acquired 30 patented mining claims and 7.5 unpatented mining claims in the Kantishna area of Denali NP\&P; these claims comprised 3.4 square kilometers. Expenditures for hazardous materials surveys, real estate appraisals, title
Land Surveys.-The NPS conducts cartographic surveys to determine the location and boundary lines of both patented and unpatented mining claims within park units. The NPS also performs photogrammetric control surveys and topographic ground surveys for the production of digital topographic maps at typical scales of 1:1,200 or 1:2,400. The maps are produced either on contract or by the NPS and are used to facilitate minerals and resource management projects, including claim acquisition, validity examinations, mining plan reviews, hazardous waste surveys, relocation projects, and property appraisals. In 1996, the NPS produced over 3,000 computer-generated cartographic, graphic, and engineering products in support of its management programs. Approximately 25 percent of these products was supplied to mining claimants, consultants, concessionaires, and other interested parties. In Wrangell-St. Elias NP\&P, a photogrammetric control survey and claim corner search was completed on 14 patented and 18 unpatented mining claims.

ABANDONED MINERAL LANDS RECLAMATION

Restoration program.-Within the NPS, abandoned mineral lands are managed under a multiphase Mineral Land Restoration program with eight major components: inventory, explosives removal, hazard signing and mitigation, hazardous material removal, debris removal, tailings and acid mine drainage remediation, recontouring and revegetation, is National Park, vith polyurethane f Denali NP\&P, as developed for n was completed taff spent 4 days ation effort; and ater quality were ion plans for the

S completed its bandoned placer of Denali NP\&P. ngs stabilization, stabilization, and transects were s of constructed er-mined stream. restored sections pruce Creek was observations of ation were made. portion of one patented claim and accepted an offer for four additional patented claims. Validity determinations, appraisal of fair market values, and other acquisition work will continue in Kantishna to support the NPS objective of purchasing all available mining claims in the area.

Cultural Resources Mining Inventory.-The Cultural Resources Mining Inventory and Monitoring Program ensures that all mining-related activities in Alaska's national parks are in full compliance with Federal historic and cultural resource protection laws and regulations. In 1996, research focused on historic activity in Wrangell-St. Elias NP\&P in the Gold Hill-Chisana Historic Mining District, where a team of archaeologists, historians, and architects continued to compile a Cultural Landscape Inventory for the district. The inventory includes many historic remains of both camps and operations of past placer mining in the area. In Denali NP\&P, research continued for the nomination of the Stampede Mine, the State's premier historic antimony mine, to the National Register of Historic Places. A draft report detailing 344 archaeological sites, primarily old lode and placer mining operations, in the Kantishna area of Denali NP\&P was completed (Saleeby, 1997). took place in two park units. In Kenai Fjor three adits and one large trench were sealed foam. In the Kantishna Mining District one mine adit was surveyed, and a plan $\mathrm{x}$ closing the adit in 1997; a reclamation pla for the Red Top Mine mill site, and NPS recontouring the site as an initial reclam background data on topography, soils, and compiled to support the design of reclama Slate Creek antimony prospect.

Reclamation research. $-\mathrm{The} \mathrm{NH}$ eighth year of reclamation studies on an mine on Glen Creek in the Kantishna Hills Research has focused on techniques for tail flood-plain and stream channel design and revegetation. Permanent cross-section resurveyed in 1996 to evaluate the succe stream channels and flood plains in the plac A study of macroinvertebrates on mined anc of Glen Creek and unmined sections of S completed (Major, 1996). Qualitative floodplain stabilization and upland revege 


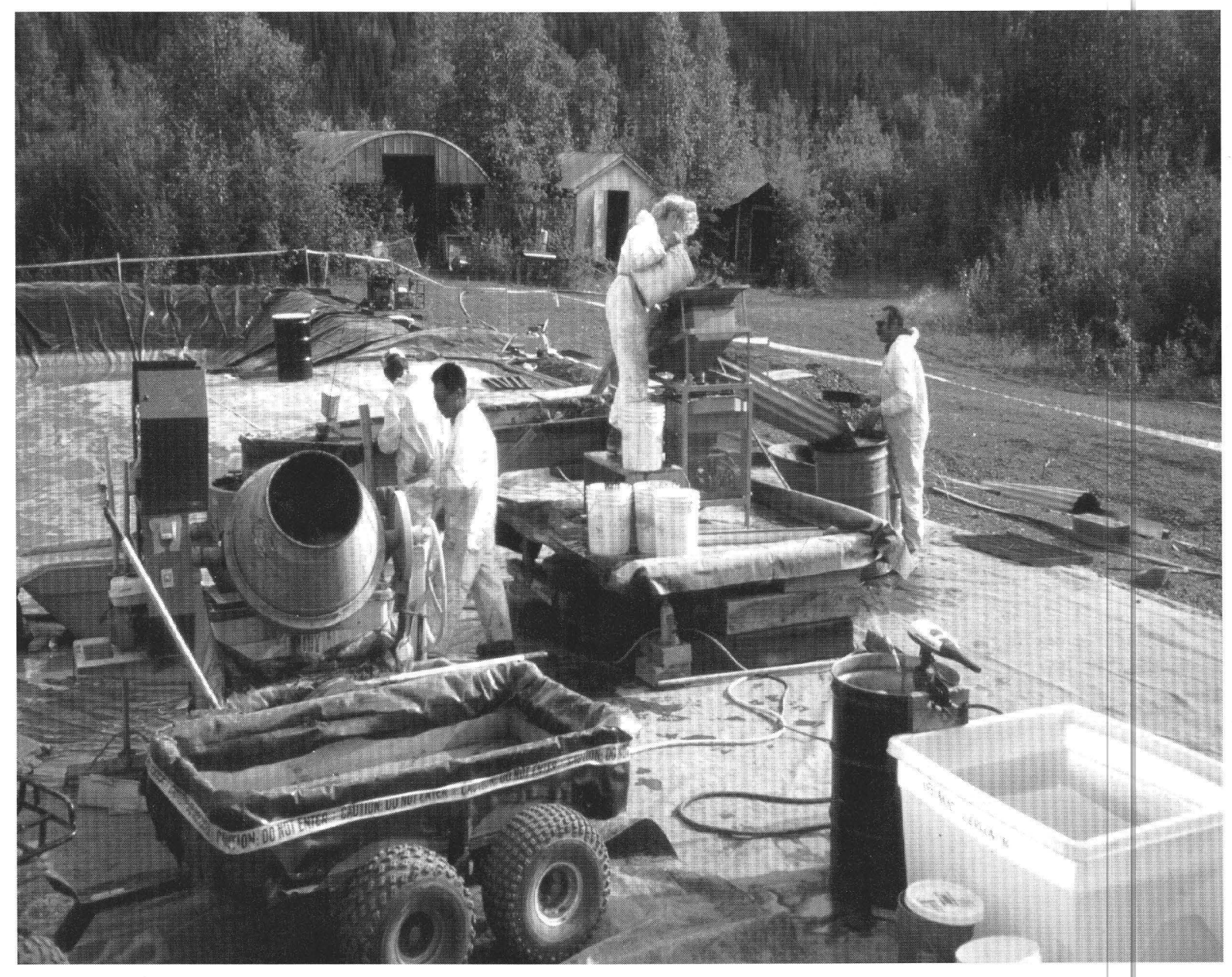

Figure 21. An NPS crew processes mercury-contaminated soil from a historic assay operation at Coal Creek in Yukon-Charley Rivers National Preserve. The contaminated soil was combined with ore-cleaning solution and reduced to slurry in a cement mixer, which assisted the physical agglomeration and separation of elemental mercury from the soil. Large mercury beads were extracted from the slurry using a soil-wash jig plant, and finer mercury particles were recovered on a copper plate. The recovered mercury was recycled for industrial use. Additional mitigation was scheduled for 1997. Photograph from NPS files.

AMRAP AUTHORIZATIONS

As mandated in Section 1010(b) of ANILCA, the NPS has regulations to authorize AMRAP activities within park units. No mineral-assessment projects were proposed by other Federal agencies during 1996.

\section{U.S. FISH AND WILDLIFE SERVICE}

Valid mining claims on lands established as national wildlife refuges by ANILCA in 1980 remain valid if they are kept active. In 1996, there were 56 active gold mining claims on 5 of the 16 refuges in Alaska, down from 68 in 1995; this reduction was due to the declaration of 12 claims as abandoned and void by the BLM. Claims were active on the Alaska Peninsula, Arctic, Innoko, Togiak, and Yukon
Major quantitative measurements of the revegetation plots were scheduled for 1998.

Remediation of hazardous waste.-Under its hazardous-waste remediation program, the NPS continued activities in three park units. In Yukon-Charley Rivers National Preserve, 3.8 cubic meters of lead-contaminated soil was removed at a historic blacksmith shop, and 11.5 cubic meters of mercury-contaminated soil was reclaimed at an abandoned assay operation associated with the former bucketline dredge at Coal Creek (fig. 21); additional cleanup at the assay was scheduled for 1997. In Kenai Fjords National Park, removal of arsenic-laden mine tailings was contracted, but the project was suspended due to bad weather and rescheduled for 1997. In Wrangell-St. Elias NP\&P, the NPS continued to evaluate abandoned mine tailings at the Nabesna Mine mill site. 
Delta NWR's. Off refuge lands, the FWS reviewed 56 CWA permit applications or permit modifications for miningrelated activities, including gold mining and gravel removal.

Mineral extraction activities occur in many drainages upstream from the Koyukuk, Nowitna, and Innoko NWR's. In 1996, the FWS published technical reports summarizing data from a study of water quality and metal and metalloid contaminants in sediments and fish in westcentral Alaska (Mueller, Snyder-Conn, and Bertram, 1996) and lynx sampling in interior Alaska (Moiteret, 1996). In addition, the FWS conducted studies at the Innoko NWR to assess the existing concentrations of metals in water, sediment, and fish tissue at the refuge boundaries.

In west-central Alaska, the FWS coordinated with State agencies, Native Alaskan organizations, and USMX to review development plans for a heap-leach gold mine at Illinois Creek, which is north and upstream of the Innoko NWR. The FWS conducted baseline monitoring activities on Illinois Creek and adjacent waterbodies, also in conjunction with State agencies and Alaska Native organizations. In northwestern Alaska, the FWS conducted breeding bird surveys at the Red Dog Mine in 1996 in cooperation with the NPS and Cominco Alaska. In the Fairbanks area, the FWS worked with the Alaska Work Group on Placer Mine Reclamation to facilitate the development of new reclamation techniques and monitored the start-up of the Fort Knox open-pit gold mine. In southeastern Alaska, the FWS reviewed task reports provided to the EPA by contractors preparing supplemental EIS's for the proposed A-J and Kensington gold mines.

\section{FOREST SERVICE}

The FS oversees minerals exploration and development on 93,000 square kilometers of NFS lands in 14 ranger districts in Alaska (fig. 5). Locatable mineralsrelated work on these lands requires FS authorization via approved Notices of Intent or approved Plans of Operation. The FS received 22 Notices and 120 Plans in 1996, up from 15 Notices and 71 Plans filed in 1995, marking renewed interest by industry in locatable minerals exploration on NFS lands.

MINERALS DEVELOPMENT ON NFS LANDS

Admiralty Island National Monument.-The Greens Creek Mine in Admiralty Island National Monument is the largest producing silver mine in the United States. The mine shut down in 1993 due to depressed metal prices, and the hiatus was used to upgrade facilities and operations. The FS approved a modified Plan of Operations in 1995, and the mine reopened in 1996 with increased reserves and improved metal prices. The Greens Creek Exchange Act became law in 1996. This agreement allows the Kennecott Greens Creek
Mining Company to explore and develop minerals in the subsurface of 30 square kilometers adjacent to its patented mining claims; access would be from the mine's underground workings. In exchange, the mining company will buy up to $\$ 1$ million of private lands within the monument and turn them over to the FS. The company will pay royalties on profits from mining on the exchange land, and ownership of the patented claims will revert to the FS in 100 years.

Juneau Ranger District.-The FS initiated a supplement to the Kensington gold project's Final EIS in order to analyze Coeur Alaska's proposed changes to the approved Plan of Operations. Major changes intended to reduce the environmental impacts of mining included offsite ore processing and tailings dehydration for dry disposal. The EPA and ACE were cooperating with the FS in preparation of the Supplemental EIS; Science Applications International Corporation, a private contractor, was preparing the analysis. The draft Supplemental EIS was released in February 1997, and the Final EIS was expected by July.

The FS cooperated with the BLM in preparing the original 1992 EIS for Echo Bay's A-J Mine project, which would have impounded Sheep Creek for the mine's tailings pond. In early 1996, the EPA began a Supplemental EIS to analyze the company's proposal for submarine tailings disposal. After Echo Bay's closure of the A-J project, the EPA stated that the Supplemental EIS would not be concluded, but the comparative risk-analysis conclusions pertaining to the submarine disposal alternative would be recorded as an interim findings report.

\section{MINERAL PATENT AND VALIDITY EXAMINATIONS}

Admiralty Island National Monument.-The Pyrola Partnership patent application involves four lode claims at Pyrola, a barite-bearing lead-zinc-silver massive-sulfide deposit on Admiralty Island. The field examination on this case was conducted in July 1993, and completion of the report was expected in April 1997.

Juneau Ranger District.-The Tracy Partnership applied for patent on three lode claims at the Tracy zinccopper-silver deposit in the Tracy Arm-Fords Terror Wilderness Area. The mineral report on this case was completed in 1994 and reevaluated in 1995, using additional data submitted by the applicants. The FS revision was forwarded to the BLM in 1996.

Thorne Bay Ranger District.-The Newman application sought patent for 11 lode claims and 2 millsite claims at the Poorman magnetite-copper-gold deposit on the Kasaan Peninsula, Prince of Wales Island. The FS mineral report, which recommended patent approval for only three of the lode claims, was approved by the BLM in 1995. The DOI asked for additional information in September 1996, and a supplemental report was forwarded to the DOI in December. 
Wrangell Ranger District.-A validity examination of the Dave's Dream claim block in the LeConte Wilderness Area was performed in 1995 in order to determine if a discovery existed on each of the four placer claims at the time specified in the Wilderness Act. However, in 1996, the BLM declared the claims null and void for lack of a small miner exclusion filing in 1995; the claimants appealed the decision, and the case is currently before the DOI Board of Land Appeals. The validity exam report was on hold pending settlement of the issue.

Chugach National Forest.-A patent exam for one placer claim on Falls Creek was in progress; the BBK \#2 claim supports a suction dredging operation for placer gold. BLM and FS personnel completed the field examination in 1995, and the report was expected by early 1997 .

EXPLORATION ON NFS LANDS

Craig Ranger District.-Exploration continued for various metals in this area: base-metal volcanogenic massive sulfides at Trocadero Bay, copper and zinc on the Ruby Tuesday claims in Cholmondeley Sound, zinc-copperlead at the Lucky Nell Mine, and gold on Lancaster Peninsula and the Nutka area.

Hoonah Ranger District.-Annual assessment work on the Apex-El Nido gold property, across Lisianski Inlet from Pelican, was the only work accomplished in 1996. The FS was awaiting receipt of the revised Plan of Operations from the project proponents, which was required as a result of the FS decision on the original environmental analysis.

Juneau Ranger District.-Echo Bay performed reclamation work at nine helicopter-supported drill sites in the Gold Fork area south of Juneau. On Admiralty Island's Mansfield Peninsula, Kennecott expanded its exploration drilling and geochemical survey on the Alaska Empire property, and Alaska Dano claimants continued a limited sampling program.

\section{COOPERATIVE WORK WITH THE BLM}

The BLM completed its 3-year assessment of mines, prospects, and mineral occurrences in the Sitka and Hoonah Ranger Districts. A progress report was released (Maas, Bittenbender, and Still, 1996), and the final report was in progress.

During 1996, the FS and BLM continued the Abandoned and Inactive Mines (AIM) inventory on the Tongass National Forest. The BLM completed reports on the 50 sites examined in the Chatham Area and the 4 sites examined in the Ketchikan Area in 1995. In 1996, BLM personnel inspected 47 additional sites in the Ketchikan Area and 8 sites in the Stikine Area, and final reports were expected by early 1997 .

\section{INDUSTRIAL MINERALS}

\section{ECONOMIC OVERVIEW}

Alaska's industrial minerals are sand, gravel, building stone, jade, and soapstone; their combined value was 10 percent of mining production in 1996. Production values of sand, gravel, and building stone rose 9 percent over 1995 levels: 9.1 million metric tons of sand and gravel was valued at $\$ 32.2$ million, and 2.7 million metric tons of building stone was valued at $\$ 23.6$ million (table 9). Quantities and values of jade and soapstone were level with 1995 production.

\section{GRAVEL}

The Anchorage Assembly approved a rezoning request that allowed the Flamingo Brothers partnership to expand its planned gravel mining operation in the northern part of the city. The permitted 22-percent increase enlarges the quarry to cover 0.11 square kilometers. A condition of the rezoning action limits mining to daytime hours.

\section{LIMESTONE}

Sealaska Corporation applied for State and Federal permits to mine the Calder limestone deposit on northern Prince of Wales Island, where a resource of 9.1 million metric tons has been identified. Mining plans include an open quarry, on-site crushing and screening operations, and a shipping facility on nearby Shakan Strait. Start-up and construction costs were anticipated at $\$ 14$ million. Production was expected to begin by July 1997 , and the deposit was expected to support 40 years of mining. Sealaska will market the limestone as a whitening agent for paper and plaster and as a buffering agent in antacids. Marble was mined at Calder in the early 1900's, but the operation shut down in 1920 after the stone proved too soft for building.

A limestone deposit was quarried near the Illinois Creek gold property for use in development and production activities at the mine. Lower-grade limestone near the top of the deposit was used to cap the access road from the airstrip and camp to the mine, leach heap, and processing facilities. The underlying, higher-grade limestone will be used to produce quick-lime for use in the gold-leaching process.

\section{GRANITE}

The National Bank of Alaska was granted a 20year conditional-use permit to remove 5.4 million metric tons of granite from company-owned land near Eklutna, northeast of Anchorage and adjacent to the Alaska Railroad Corporation's existing granite quarry. However, local residents opposed the quarry, and mining plans were deferred 


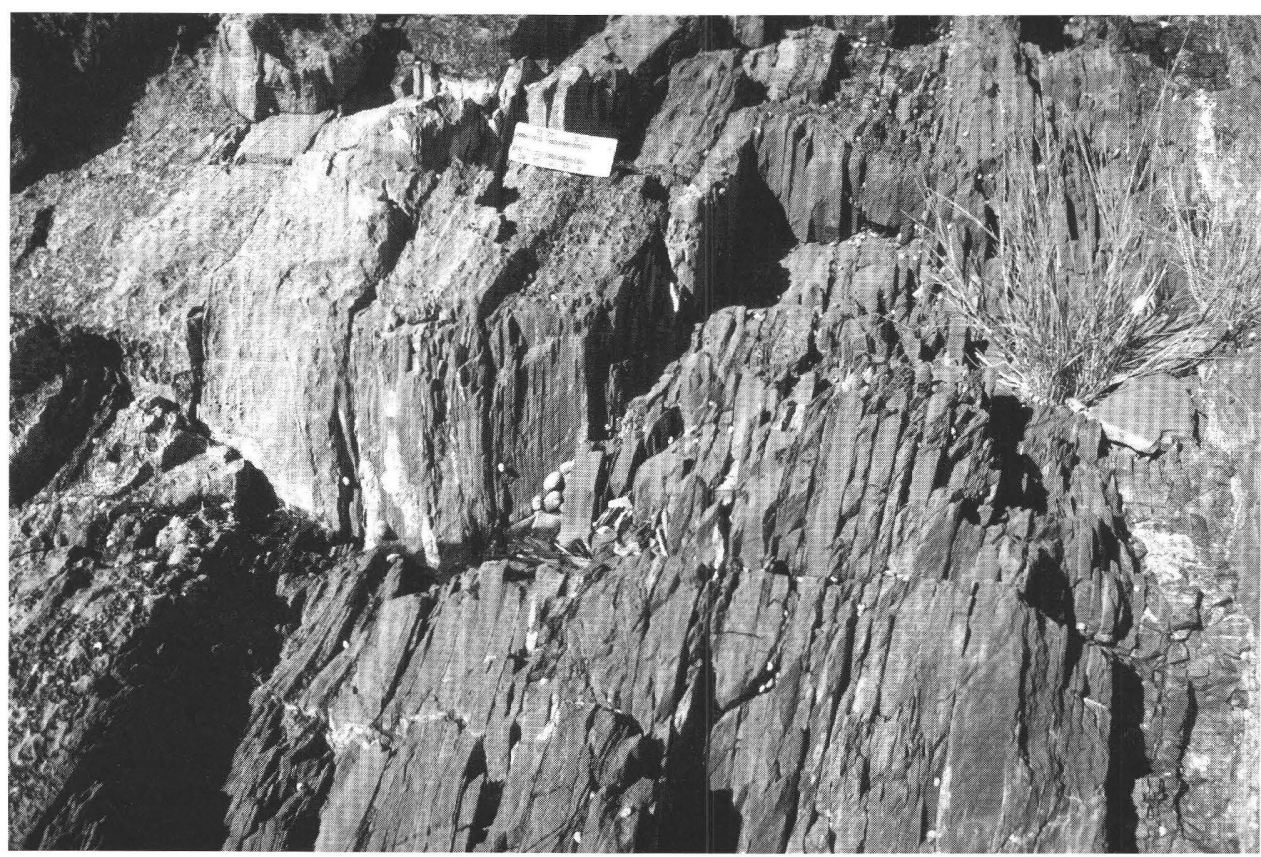

Figure 22. Kennel Creek limestone on northeastern Chichagof Island, a tract included in the USGS geologic map of an FS ecosystem study area. Limestone and marble were historically mined in southeastern Alaska for building stone, and Sealaska Corporation has applied for permits to reopen the Calder limestone mine on Prince of Wales island. Photograph by S. Karl, USGS.

after the discovery was announced of an alternate granite deposit in the Knik River valley.

\section{ACTIVITY BY FEDERAL AGENCIES}

\section{U.S. GEOLOGICAL SURVEY}

In the Tongass National Forest, the USGS developed an Interagency Agreement with the FS to provide geologic expertise for an assessment of limestone resources on Chichagof Island (fig. 22); fieldwork was performed in 1996. Limestone is used for construction and for mitigation of acid mine drainage.

A surficial geologic map for northeast Anchorage was published (Schmoll, Yehle, and Dobrovolny, 1996). The map shows the distribution of glacial debris; clay, silt, sand, and gravel deposits; engineered fill; peaty material; landslides; and bedrock. Such maps are useful for assessing the resource potential of industrial minerals in an area.

\section{BUREAU OF LAND MANAGEMENT}

The BLM began work in 1996 on a project for the FS to survey the mineral materials of the Chugach National Forest in south-central Alaska. Aggregate, shot-rock, rip- rap, and other construction materials were the main focus of the investigation; granite and granodiorite, limestone, marl, shales, and other building stone were also examined.

Fieldwork was conducted along road corridors in the southern part of the Seward Ranger District. Rock and sediment samples were gathered, and quality tests were performed on sand, gravel, and rock to determine their suitability for aggregate in road construction and pavement. Geophysical surveys using ground-penetrating radar were conducted at most of the accessible sites. This technique provided rapid imaging of the subsurface to show depths to groundwater and bedrock and was a low-cost alternative to trenching for thickness determination of sand and gravel deposits; however, it could not provide information on quality of buried materials. Where surveys identified usable volumes in gravel deposits, subsequent testing measured the construction quality and grade of the material. An administrative report detailing the results of 1996 fieldwork was to be completed in 1997.

\section{U.S. FISH AND WILDLIFE SERVICE}

When compatible with refuge purposes, the FWS issues special-use permits for the sale and extraction of sand and gravel to support development activities in rural communities. The FWS made the following gravel sales on 
the listed refuges in 1996: Alaska Maritime, 1; Arctic, 1; Izembek, 9; Yukon Delta, 3.

\section{FOREST SERVICE}

The FS annually conducts sales and issues permits for the removal of sand, gravel, and stone from NFS lands. Most of this material is used in the construction of timbersale roads and by State and local governments for the construction and maintenance of roads, breakwaters, and airports. Nearly 1.5 million cubic meters of shot rock, sand, and gravel was disposed through in-service use, material sales, and Free-Use Permits on the Tongass National Forest in 1996. Most of this material was utilized for FS and Native corporation timber road construction. On the Chugach National Forest, approximately 49,700 cubic meters was disposed through material sales and FreeUse Permits. The majority was used on construction of Native corporation timber roads on Montague Island in Prince William Sound. 


\section{_SELECTED REFERENCES-}

The following publications contain pertinent information about energy and nonfuel-mineral resources in Alaska. Reports by Federal or State agencies can generally be obtained from the agency offices in Alaska (see "Contacts for Further Information") or are available at the Alaska Resources Library and Information Services (ARLIS), 3150 C Street, Suite 100, Anchorage, AK 99503. Many reports are also available from the U.S. Government Printing Office in Washington, DC, or from the National Technical Information Service (NTIS) in Springfield, VA 22161.

Agler, B.A., Seiser, P.E., Kendall, S.J. and Irons, D.B. 1995, Winter marine bird and sea otter abundance of Prince William Sound, Alaska-Trends following the T/V Exxon Valdez oil spill from 1990-94: Anchorage, Alaska, U.S. Fish and Wildlife Service Administrative Report, 68 p.

Alaska Business Monthly [published monthly by Alaska Business Publishing Company, Box 241288, Anchorage AK 99524-1288].

Alaska Division of Geological and Geophysical Surveys, Dighem, and WGM, 1995, Total field magnetics and electromagnetic anomalies of the Fairbanks Mining District: Alaska Division of Geological and Geophysical Surveys Report of Investigations 95-4, 2 sheets, scale $1: 63,360$.

1996a, $900 \mathrm{~Hz}$ resistivity contours of the Rampart-Manley Mining District, Alaska: Alaska Division of Geological and Geophysical Surveys Report of Investigations 96-3, 2 sheets, scale 1:63,360.

1996b, 7200Hz resistivity contours of the Rampart-Manley Mining District, Alaska: Alaska Division of Geological and Geophysical Surveys Report of Investigations 96-4, 2 sheets, scale 1:63,360.

1996c, Total field magnetics of the Rampart-Manley Mining District, Alaska: Alaska Division of Geological and Geophysical Surveys Report of Investigations 96-2, 2 sheets, scale $1: 63,360$.

1996d, Total field magnetics and electromagnetic anomalies of the Rampart-Manley Mining District, Alaska: Alaska Division of Geological and Geophysical Surveys Report of Investigations 96-1, 2 sheets, scale 1:63,360.

Alaska Journal of Commerce [published weekly by OCA Publishing, 3710 Woodland Drive, Suite 2100, Anchorage AK 99517].

Alaska Oil and Gas Conservation Commission, 1997, 1996 Annual Report: Anchorage, Alaska, Alaska Oil and Gas Conservation Commission, $251 \mathrm{p}$.
Alaska Oil and Gas Conservation Commission Bulletin [published monthly by the State of Alaska, Alaska Oil and Gas Conservation Commission, 3001 Porcupine Drive, Anchorage, AK 99501].

Alaska Report [published weekly by Petroleum Information Corporation, P.O. Box 2612, Denver, CO 80201-2612].

American Society for Testing and Materials, 1980, Standard for metric practive: Philadelphia, PA, American Society for Testing and Materials Publication E380-79, 42 p.

Anchorage Daily News [published daily by Anchorage Daily News Incorporated, 1001 Northway Drive, Anchorage AK 99508].

Attanasi, E.D., and Bird, K.J., 1996, Economics and undiscovered conventional oil and gas accumulations in the 1995 National Assessment of U.S. oil and gas resources-Alaska: U.S. Geological Survey Open-File Report 95-75-J, 48 p.

Bailey, E.A., and Gray, J.E., 1997, Mercury in the terrestrial environment, Kuskokwim Mountains region, southwestern Alaska: U.S. Geological Survey Professional Paper 1574, p. 41-56.

Bailey, E.A., Keith, W.J., Bickerstaff, D., Dempsey, D., and Miller, M.L., 1996, Analytical results and sample locality maps of stream-sediment, panned concentrate, stream-water, and soil samples from the Stuyahok study area, part of Holy Cross A-4 and A-5 quadrangles, Alaska: U.S. Geological Survey Open-File Report 96-505-C, 46 p.

Banet, A.C., Jr., 1995, Chemical correlations among Arctic oils-Will the circle be unbroken? [abs.]: Geological Society of America Abstracts with Programs, v. 27, no. 5, p. 4.

1997, An overview of potential conflicts between high-density caribou calving areas and petroleum development in the Arctic Wildlife Refuge [abs.]: American Association of Petroleum Geologists Annual Convention, Dallas, Texas, April 6-9, 1997, Official Program, p. A6-A7.

Banet, A.C., Jr., and Mowatt, T.C., 1997, Enigmatic source of oil from the Chukchi Sea, northwest Alaska in Clough, J.C., ed., 1997, Short notes on Alaskan geology: Alaska Division of Geological and Geophysical Surveys Special Publication [in press].

Bayha, K.D., 1996, Criteria for instream water rights for selected 1002 area lakes, Arctic National Wildlife Refuge: Anchorage, Alaska, U.S. Fish and Wildlife Service, Water Resources Branch, Report WRB 96-5, 208 p.

Brew, D.A., compiler, 1996, Geologic map of the Craig, Dixon Entrance, and parts of the Ketchikan and Prince Rupert quadrangles, southeastern Alaska: U.S. Geological Survey 
Miscellaneous Field Studies Map MF-2319, 53 p., 1 sheet, scale 1:250,000.

Brew, D.A., Grybeck, D.J., Taylor, C.D., Jachens, R.C., Cox, D.P., Barnes, D.F., Koch, R.D., Morin, R.L., and Drinkwater, J.L., 1996, Undiscovered mineral resources of southeastern Alaska-Revised mineral-resourceassessment-tract descriptions: U.S. Geological Survey Open-File Report 96-716, 131 p., 1 sheet, scale $1: 100,000$.

Bundtzen, T.K., Swainbank, R.C., Clough, A.H., Henning, M.W., and Charlie, K.M., 1996, Alaska's mineral industry 1995: Alaska Division of Geological and Geophysical Surveys Special Report 50, 72 p.

_1996, Alaska's Mineral Industry 1995-Summary: Alaska Division of Geological and Geophysical Surveys, Information Circular 41, $12 \mathrm{p}$.

Bureau of Land Management, 1990, Federal lands in Alaska: Bureau of Land Management Land Status Map BLMAK-GI-90-030-112-924, 1 sheet, scale, 1:2,500,000.

_-1996, Bureau of Mines publications on Alaska-A bibliography: U.S. Bureau of Land Management, BLMAlaska Open File Report 63, 124 p.

Church, S.E., Kelley, J.S., and Bohn, D., 1996, Mineral-resource assessment of the Chandler Lake quadrangle, Alaska: U.S. Geological Survey Miscellaneous Field Studies Map MF-2144-E, 37 p., 1 sheet, scale 1:250,000.

Clough, N.K., Patton, P.C., and Christiansen, A.C., eds., 1987, Arctic National Wildlife Refuge, Alaska, coastal plain resource assessment-Report and recommendation to the Congress of the United States and Final Legislative Environmental Impact Statement: Washington, DC, U.S. Fish and Wildlife Service, U.S. Geological Survey, and Bureau of Land Management, 2 volumes, 208 p.

Collett, T.S., 1996a, Geologic assessment of the natural gas-hydrate resources in the onshore and offshore regions of the United States: International Conference on Natural Gas Hydrates, 2nd, Toulouse, France, June 2-6, 1996, Proceedings, p. 499-506.

$1996 \mathrm{~b}$, Sources of surficial methane flux associated with natural gas hydrate accumulations in northern Alaska [abs.]: Eos Transactions of the American Geophysical Union, v. 77, no. 46, Fall Meeting Supplement, p. F184.

Deming, D., Sass, J.H., and Lachenbruch, A.H., 1996, Heat flow and subsurface temperature, North Slope of Alaska: U.S. Geological Survey Bulletin 2142, p. 21-44.

Detterman, R.L., Case, J.E., Miller, J.W., Wilson, F.H., and Yount, M.E., 1996, Stratigraphic framework of the Alaska Peninsula: U.S. Geological Survey Bulletin 1969-A, 74 p.

Dodd, Stan, 1996, Donlin Creek Project, southwest Alaska [abs.], in Alaska mining-No longer just a dream: Alaska Miners Association Annual Convention, Anchorage, Alaska, 1996, [Abstracts], p. 27-28.

Duffy, D.C., compiler, 1996, APEX-Alaska Predator Ecosystem
Experiment: Anchorage, Alaska, U.S. Fish and Wildlife Service, Exxon Valdez Oil Spill Restoration Project Number 96163, Annual Report, 28 p.

Dumoulin, J.A., and Gray, J.E., eds., 1997, Geologic studies in Alaska by the U.S. Geological Survey, 1995: U.S. Geological Survey Professional Paper 1574, 328 p.

Dumoulin, J.A., and Harris, A.G., 1997, Kinderhookian (Lower Mississippian) calcareous rocks of the Howard Pass quadrangle, west-central Brooks Range: U.S. Geological Survey Professional Paper 1574, p. 243-268.

Dusel-Bacon, C., Brew, D.A., and Douglass, S.L., 1996, Metamorphic facies map of southeastern AlaskaDistribution, facies, and ages of regionally metamorphosed rocks: U.S. Geological Survey Professional Paper 1497-D, 42 p., 2 sheets, scale 1:1,000,000.

Dusel-Bacon, C., Doyle, E.O., and Box, S.E., 1996, Distribution, facies, ages, and proposed tectonic associations of regionally metamorphosed rocks in southwestern Alaska and the Alaska Peninsula: U.S. Geological Survey Professional Paper 1497-B, 30 p., 2 sheets, scale 1:1,000,000.

Eppinger, R.G., Sutley, S.J., and McHugh, J.B., 1997, Environmental geochemical study of the Nabesna gold skarn and Kennecott strata-bound copper deposits, Alaska: U.S. Geological Survey Professional Paper 1574, p. 19-39.

Exxon Valdez Oil Spill Trustee Council, 1996, Fiscal Year 1996 work plan-Detailed project descriptions, April 1996: Anchorage, Alaska, Exxon Valdez Oil Spill Trustee Council, Oil Spill Public Information Center.

Fairbanks Daily News-Miner [published 6 days a week by the Fairbanks Publishing Company, 200 North Cushman, Fairbanks AK 99701]

Flores, R.M., Stricker, G.D., and Stiles, R.B., 1997, Tidal influence on deposition and quality of coals in the Miocene Tyonek Formation, Beluga coal field, upper Cook Inlet, Alaska: U.S. Geological Survey Professional Paper 1574, p. 137156.

Ford, R.C., and Snee, L.W., 1996, ${ }^{40} \mathrm{Ar} /{ }^{39} \mathrm{Ar}$ thermochronology of white mica from the Nome District, Alaska-The first ages of lode sources to placer gold deposits in the Seward Peninsula: Economic Geology, v. 91, p. 213-220.

Galloway, J.P., and Toussaint, S., 1997a, Reports about Alaska in non-USGS publications released in 1995 that include USGS authors: U.S. Geological Survey Professional Paper 1574, p. 323-328.

1997b, U.S. Geological Survey reports on Alaska released in 1995: U.S. Geological Survey Professional Paper 1574, p. 317-321.

Gautier, D.L., Dolton, G.L., Takahashi, K.I., and Varnes, K.L., eds., 1995, 1995 National assessment of United States oil and gas resources-Results, methodology, and supporting data: U.S. Geological Survey Digital Data Series DDS-30, 1 CD-ROM. 
Goatcher, B., Zwiefelhofer, D., Esler, D. and Scribner, K., 1996, Differentiation and interchange of harlequin duck populations within the North Pacific: Kodiak, Alaska, U.S. Fish and Wildlife Service, Exxon Valdez Oil Spill Restoration Project Number 97161, Progress Report, $16 \mathrm{p}$.

Goldfarb, R.J., 1996, Metallogenic evolution of Alaska [abs.]: International Geological Congress, 30th, Beijing, 1996, Abstracts, v. 1, p. 395.

Goldfarb, R.J., Nelson, S.W., Taylor, C.D., d'Angelo, W.M., and Meier, A.L., 1996, Acid mine drainage associated with volcanogenic massive sulfide deposits, Prince William Sound, Alaska: U.S. Geological Survey Bulletin 2152, p. 3-16.

Goldfarb, R.J., Skinner, D., Christie, A.B., Haeussler, P.J., and Bradley, D.C., 1995, Mesothermal gold deposits of Westland, New Zealand and Southern AlaskaProducts of similar tectonic processes?, in Mauk, J.L., ed., Proceedings of the 1995 PACRIM Congress: Australian Institute of Mining and Metallurgy, p. 239244.

Goldfarb, R.J., Taylor, C.D., Meier, A.L., d'Angelo, W.M., and O’Leary, R.M., 1997, Hydrogeochemistry of minedrainage waters associated with low-sulfide, goldquartz veins in Alaska: U.S. Geological Survey Professional Paper 1574, p. 3-17.

Gough, L.P., and Crock, J.G., 1997, Distinguishing between natural geologic and anthropogenic trace element sources, Denali National Park and Preserve: U.S. Geological Survey Professional Paper 1574, p. 5771.

Grauch, V.J.S., and Castellanos, E., 1995, Revised digital aeromagnetic data for areas in and adjacent to the National Petroleum Reserve area (NPRA), North Slope, Alaska: U.S. Geological Survey Open-File Report 95-835, 11 p.

Gray, J.E., Meier, A.L., O’Leary, R.M., Outwater, C., and Theodorakos, P.M., 1996, Environmental geochemistry of mercury deposits in southwestern Alaska-Mercury contents in fish, stream-sediment, and stream-water samples: U.S. Geological Survey Bulletin 2152, p. 17-29.

Gray, J.E., and Sanzolone, R.F., eds., 1996, Environmental studies of mineral deposits in Alaska: U.S. Geological Survey Bulletin 2156, $40 \mathrm{p}$.

Gray, J.E., and Theodorakos, P.M., 1997, Areas favorable for metallic mineral resources and newly discovered mineral occurrences in the Buckstock Mountains area, southwestern Alaska: U.S. Geological Survey Professional Paper 1574, p. 111-123.

Grybeck, D.J., Nelson, S.W., Cathrall, J.B., Cady, J.W. and Le Compte, J.R., 1996, Mineral-resource potential map of the Survey Pass quadrangle, Brooks Range, Alaska: U.S. Geological Survey Miscellaneous Field Studies
MF-Map 1176-I, 16 p., 1 sheet, scale 1:250,000.

Haeussler, P.J., and Bradley, D.C., 1996, Structural characteristics of ridge-subduction related gold deposits in Southern Alaska [abs.]: Geological Society of America, Abstracts with Programs, v. 28, no. 5, p. 71-72.

Harris, A.G., Brenckle, P.L., Baesemann, J.F., Krumhardt, A.P., and Gruzlovic, P.D., 1997, Comparison of conodont and calcareous microfossil biostratigraphy and lithostratigraphy of the Lisburne Group (Carboniferous), Sadlerochit Mountains, northeast Brooks Range, Alaska: U.S. Geological Survey Professional Paper 1574, p. 195-219.

Hayes, D.L., and Spencer, T., 1996, A comparison of the breeding and feeding ecology of pigeon guillemots in Prince William Sound and Kachemak Bay, Alaska, Appendix F in Duffy, D.C., compiler, APEX-Alaska Predator Ecosystem Experiment: Anchorage, Alaska, U.S. Fish and Wildlife Service, Exxon Valdez Oil Spill Restoration Project Number 96163, Annual Report, p. 1-34.

Hayes, D.L., and Kuletz, K.J., 1997, Decline of pigeon guillemot populations in Prince William Sound and apparent changes in distribution and abundance of their prey, in The Role of Forage Fishes in Marine Ecosystems: Anchorage, Alaska, November 1996, Symposia Proceedings, Alaska Sea Grant Publication [in press].

Irons, D.B., Kuletz, K.J., and Suryan, R.M., 1996, Restoration and monitoring of other seabird species: Exxon Valdez. Oil Spill Seabird Restoration Workshop, Annual Report to the Exxon Valdez Oil Spill Trustee Council.

Irons, D.B., and Suryan, R.M., 1996, Kittiwakes as indicators of change in forage fish, Appendix E in Duffy, D.C., compiler, APEX-Alaska Predator Ecosystem Experiment: Anchorage, Alaska, U.S. Fish and Wildlife Service, Exxon Valdez Oil Spill Restoration Project Number 96163, Annual Report, p. 1-31.

Jacobson, S.R., Blodgett, R.B., and Babcock, L.E., 1996, Organic matter and thermal maturation of lower Paleozoic rocks from the Nixon Fork subterrane of the Farewell terrane, west-central and southwestern Alaska: U.S. Geological Survey Bulletin 2152, p.81-87.

Johnsson, M.J., and Howell, D.G., compilers, 1996a, Generalized thermal maturity map of Alaska: U.S. Geological Survey Miscellaneous Investigations Series Map I2494, 1 sheet, scale 1:2,500,000.

—eds., 1996b, Thermal evolution of sedimentary basins in Alaska: U.S. Geological Survey Bulletin 2142, 131 p., 1 sheet, scale 1:2,500,000.

1996c, Thermal maturity of sedimentary basins in AlaskaAn overview: U.S. Geological Survey Bulletin 2142, p. 1-9.

Johnsson, M.J., Pawlewicz, M.J., Harris, A.G., and Valin, Z.C., 1992, Vitrinite reflectance and conodont color alteration index data from Alaska-Data to accompany 
the thermal maturity map of Alaska: U.S. Geological Survey Open-File Report 92-409, three 1.44MB Macintosh diskettes.

Karl, S.M., 1996, Preliminary geologic map of northest Chichagof Island: U.S. Geological Survey Open-File Report 9653, 1 sheet, scale 1:63,360.

Keith, W.J., and Miller, M.L., 1996a, Alaska Resource Data FileHoly Cross quadrangle: U.S. Geological Survey OpenFile Report 96-685, 4 p.

1996b, Alaska Resource Data File-Iditarod quadrangle: U.S. Geological Survey Open-File Report 96-540, 36 p.

Keith, W.J., Miller, M.L., Bailey, E.A., Bundtzen, T.K., and Bickerstaff, D., 1996, Analytical results and sample locality maps of rock samples from the Stuyahok area, part of Holy Cross A-4 and A-5 quadrangles, Alaska: U.S. Geological Survey Open-File Report 96-505-B, 47 p., scale 1:63,360.

Kelley, J.S., 1997a, Alaska Resource Data File-Demarcation Point quadrangle: U.S. Geological Survey Open-File Report 96-678, 13 p.

1997b, Alaska Resource Data File-Mount Michelson quadrangle: U.S. Geological Survey Open-File Report, 96-681, 21 p.

_ 1997c, Alaska Resource Data File-Umiat quadrangle: U.S. Geological Survey Open-File Report 96-679, 6 p.

Kelley, K.D., Bailey, E.A., Briggs, P.H., Motooka, J.M., and Meier, A.L., 1996, Digital release of stream-sediment, heavymineral-concentrate, soil, water, and rock geochemical data collected in the Howard Pass $1^{\circ} \mathrm{X} 3^{\circ}$ quadrangle, Alaska: U.S. Geological Survey Open-File Report 96$711,3.5^{\prime \prime}$ diskette.

Kelley, K.D., Goldfarb, R.J., Gray, J.E., Taylor, C.D., and Plumlee, G.S., 1996, Geoenvironmental mineral deposit models of Alaska [abs.]: International Geological Congress, 30th, Beijing, 1996, Abstracts, v. 3, p. 53.

Kelley, K.D., and Taylor, C.D., 1996, Natural environmental effects associated with the Drenchwater zinc-lead-silver massive sulfide deposit with comparisons to the Red Dog and Lik deposits, west-central Brooks Range, Alaska: U.S. Geological Survey Bulletin 2152, p. 31-45.

Kelley, K.D., Taylor, C.D., and Cieutat, B.A., 1997, Silver-leadzinc mineral occurrences in the Howard Pass quadrangle, Brooks Range, Alaska: U.S. Geological Survey Professional Paper 1574, p. 101-110.

Kirschner, C.E., 1988, Map showing sedimentary basins of onshore and continental shelf areas, Alaska: U.S. Geological Survey Miscellaneous Investigations Series Map I-1873, 1 sheet, scale 1:2,500,000.

Krumhardt, A.P., Harris, A.G., and Watts, K.F., 1996, Lithostratigraphy, microlithofacies, and conodont biostratigraphy and biofacies of the Wahoo Limestone (Carboniferous), eastern Sadlerochit Mountains, northeast Brooks Range, Alaska: U.S. Geological Survey Professional Paper 1568, 81 p.

Kuletz, K.J., 1996, Developing a productivity index for murrelets [abs.], in 1996 Restoration Workshop: Anchorage, Alaska, January 1996, Abstracts of 1995 Restoration Project Results, Exxon Valdez Oil Spill Trustee Council.

Kuletz, K.J. and Agler, B., 1996, Status of the marbled murrelet in Alaska and restoration studies following the Exxon Valdez oil spill [abs.]: Fairbanks, Alaska, April 1996 Alaska Bird Conference, 6th, Abstracts.

Kuletz, K.J., Irons, D.B., Piatt, J.F., Agler, B., and Duffy, D.C., 1997, Long-term changes in populations and diets of piscivorous birds and mammals in Prince William Sound, Alaska, reflect a shift in prey species abundance, in The role of forage fishes in marine ecosystems: Anchorage, Alaska, November 1996, Symposia Proceedings, Alaska Sea Grant Publication [in press].

Kuletz, K.J., Kendall, S.J., and Flint, D.A., 1996, A marbled murrelet productivity index for Prince William Sound, Alaska, and factors affecting murrelet density at sea: Anchorage, Alaska, U.S. Fish and Wildlife Service, Exxon Valdez Oil Spill Restoration Project Number 95031, Final Report, 50 p.

Lappi, D., 1996, Development of coalbed methane gas: Alaska Miner, v. 24, no. 8, p. 14 and 18.

Lee, M.W., Hutchinson, D.R., Collett, T.S., and Dillon, W.P., 1996, Seismic velocities for hydrate-bearing sediments using weighted equation: Journal of Geophysical Research, v. 101 , no. B9, p. 20,347-20,358.

Leonard, K.R., and Huber, D.F., 1987, Status of Alaska Mineral Resources Data System: U.S. Geological Survey Circular 998, p. 15-18.

Maas, K.M., Bittenbender P.E., and Still, J.C., 1996, Mineral investigations on Baranof and Chichagof Islands and vicinity, southeast Alaska, 1995: Anchorage, Alaska, Bureau of Land Management, BLM-Alaska Open File Report 60, 112 p., 2 sheets, scale 1:316,800.

Major, E.B., 1996, Macroinvertebrate analysis to assess stream restoration for the U.S. National Park Service: Anchorage, Alaska, University of Alaska Environment and Natural Resources Institute, 24 p. + appendix.

Maniscalco, J.M., and Ostrand, W.D., 1997, Seabird behavior at forage fish schools in Prince William Sound, Alaska, in The role of forage fishes in marine ecosystems: Anchorage, Alaska, November 1996, Symposia Proceedings, Alaska Sea Grant Publication [in press].

Meyer, J.F., Jr., and Saltus, R.W., 1995, Merged aeromagnetic map of Interior Alaska: U.S. Geological Survey Geophysical Investigations Map GP-1014, 2 sheets, scale 1:500,000.

Meyer, J.F., Jr., Saltus, R.W., Barnes, D.F., and Morin, R.L., 1996, Bouguer gravity map of interior Alaska: U.S. Geological Survey Geophysical Investigations Map GP-1016, 2 sheets, scale 1:500,000.

Miller, L.D., and Goldfarb, R.J., 1996, Metallogeny of the Juneau gold belt-Alaska's largest gold system [abs.]: International Geological Congress, 30th, Beijing, 1996, Abstracts, v. 2, p. 780.

Miller, L.D., Goldfarb, R.J., Snee, L.W., McClelland, W.C., and 
Klipfel, P.D., 1997, Paleocene molybdenum mineralization in the eastern Coast batholith, Taku River region, and new age constraints on batholith evolution: U.S. Geological Survey Professional Paper 1574, p. 125-135.

Miller, M.L., Bundtzen, T.K., Keith, W.J., Bailey, E.A., and Bickerstaff, D., 1996, Geology and mineral resources of the Stuyahok area, part of Holy Cross A-4 and A-5 quadrangles, Alaska: U.S. Geological Survey OpenFile Report 96-505-A, 30 p., scale 1:63,360.

Minerals Management Service, 1994, Alaska environmental studies strategic plan-Fiscal years 1996-1997: Anchorage, Alaska, U.S. Department of the Interior, Minerals Management Service, Alaska OCS Region, $88 \mathrm{p}$.

-1995a, Beaufort Sea planning area oil and gas Lease Sale 144, draft Environmental Impact Statement: Minerals Management Service OCS EIS/EA, MMS 95-0043, variously paged.

1995b, Gulf of Alaska/Yakutat planning area oil and gas Lease Sale 158, draft Environmental Impact Statement: Minerals Management Service OCS EIS/EA, MMS 950054 , variously paged.

1995c, Outer Continental Shelf draft proposed leasing program, 1997 to 2002: Anchorage, Alaska, Minerals Management Service, $168 \mathrm{p}$.

1996a, An assessment of the undiscovered hydrocarbon potential of the Nation's Outer Continental Shelf: Minerals Management Service OCS Report, MMS 960034, $53 \mathrm{p}$.

1996b, Beaufort Sea planning area oil and gas Lease Sale 144, final environmental impact statement: Minerals Management Service OCS EIS/EA, MMS 96-0012, 2 volumes, variously paged.

1996c, Cook Inlet planning area oil and gas Lease Sale 149, final Environmental Impact Statement: Minerals Management Service OCS EIS/EA, MMS 95-0066, 2 volumes, variously paged.

1996d, Outer Continental Shelf oil and gas leasing program, 1997-2002-Draft Environmental Impact Statement: Minerals Management Service OCS EIS/EA, MMS 950006, 2 volumes, variously paged.

_1996e, Proposed final Outer Continental Shelf oil and gas leasing program, 1997 to 2002: Anchorage Alaska, Minerals Management Service, $160 \mathrm{p}$.

Mining Week [published weekly by the National Mining Association, 1130th Street NC, Washington DC, 20036].

Moitoret, C.S., 1996, Organochlorine pesticide and metal concentrations in two lynx from the Robertson River area, Alaska: Fairbanks, Alaska, U.S. Fish and Wildlife Service, Northern Alaska Ecological Services, Technical Report NAES-TR-96-01, 12 p.

Moitoret, C.S., Walker, T.R., and Martin, P.D., 1996, Predevelopment surveys of nesting birds at two sites in the Kuparuk oilfield, Alaska, 1988-1992: Fairbanks, Alaska, U.S. Fish and Wildlife Service, Northern Alaska Ecological Services, Technical Report NAES-TR-96-02, $104 \mathrm{p}$.

Molenaar, C.M., 1996, Thermal maturity patterns and geothermal gradients on the Alaska Peninsula: U.S. Geological Survey Bulletin 2142, p. 11-19.

Moore, T.E., and Dumoulin, J.A., eds., 1996, Geologic studies in Alaska by the U.S. Geological Survey, 1994: U.S. Geological Survey Bulletin 2152, $217 \mathrm{p}$.

Moore, T.E., Hemming, S., Sharp, W.D., 1997, Provenance of the Carboniferous Nuka Formation, Brooks Range, AlaskaA multicomponent isotope provenance study with implications for age of cryptic crystalline basement: U.S. Geological Survey Professional Paper 1574, p. 173-194.

Morin, R.L., 1996, Complete Bouguer and isostatic gravity maps of the Bethel and southern part of the Russian Mission quadrangles, southwestern Alaska: U.S. Geological Survey Miscellaneous Field Studies Map MF-2226-B, 2 sheets, scale 1:250,000.

Mueller, K.A., Snyder-Conn, E., and Bertram, M., 1996, Water quality and metal and metalloid contaminants in sediments and fish of Koyukuk, Nowitna, and the northern unit of Innoko National Wildlife Refuges, Alaska, 1991: Fairbanks, Alaska, U.S. Fish and Wildlife Service, Northern Alaska Ecological Services, Technical Report NAES-TR-96-03, $79 \mathrm{p}$.

Mull, C.G., Harris, A.G., and Carter, J.L., 1997, Lower Mississippian (Kinderhookian) biostratography and lithostratigraphy of the western Endicott Mountains, Brooks Range, Alaska: U.S. Geological Survey Professional Paper 1574, p. 221-242.

Mull, C.G., Moore, T.E., Harris, E.E., and Tailleur, I.L.,1996, Geologic map of the Killik River quadrangle, Brooks Range, Alaska: U.S. Geological Survey Open-File Report 94-679, 1 sheet, scale 1:125,000.

Nokleberg, W.J., Bundtzen, T.K., Dawson, K.M., Eremin, R.A., Goryachev, N.A., Koch, R.D., Ratkin, V.V., Rozenblum, I.S., Shpikerman, V.I., Frolov, Y.F., Gorodinsky, M.E., Melnikov, V.D., Diggles, M.F., Ognyanov, N.V., Petrachenko, E.D., Petrachenko, R.I., Pozdeev, A.I., Ross, K.V., Wood, D.H., Grybeck, D., Khanchuk, A.I., Kovbas, L.I., Nekrasov, I.Y., and Sidorov, A.A., 1996, Significant metalliferous and selected non-metalliferous lode deposits and placer districts for the Russian Far East, Alaska, and the Canadian Cordillera: U.S. Geological Survey Open-File Report 96-513 (A=460 p., B=CDROM).

Norcross, B.L., Holladay, B.A., Dressel S.C., and Frandsen, M., 1996, Recruitment of juvenile flatfishes in Alaska-Habitat preference near Kodiak Island-Final report and appendixes: Minerals Management Service OCS Study, MMS 96-0003, 2 vols.

Oakley, K.L., Wade, T.L., and Irons, D.B., 1997, Aliphatic and polycyclic aromatic hydrocarbons in eggs, livers, and 
stomach contents of black-legged kittiwakes in Prince William Sound, Alaska, after the Exxon Valdez oil spill: Anchorage, Alaska, U.S. Fish and Wildlife Service Administrative Report [in press].

Ostrand, W.D., Coyle, K.O., Drew, G.S., Maniscalco, J.M., and Irons, D.B., 1997, Selection of forage fish schools by murrelets and tufted puffins in Prince William Sound, Alaska, in The role of forage fishes in marine ecosystems: Anchorage, Alaska, November 1996, Symposia Proceedings, Alaska Sea Grant Publication [in press].

O'Sullivan, P.B., 1996, Late Mesozoic and Cenozoic thermo-tectonic evolution of the North Slope foreland basin, Alaska: U.S. Geological Survey Bulletin 2142, p. 45-79.

Philpotts, J.A., Taylor, C.D., and Baedecker, P.A., 1996, Rare-earth enrichment at Bokan Mountain, southeast Alaska: U.S. Geological Survey Bulletin 2152, p. 89-100.

Reiser, E.R., compiler, 1996, Reports about Alaska in non-USGS publications released in 1994 that include USGS authors: U.S. Geological Survey Bulletin 2152, p. 205-211.

-1996, U.S. Geological Survey reports on Alaska released in 1994: U.S. Geological Survey Bulletin 2152, p. 213-217.

Saleeby, B.M., 1997, The quest for gold-An overview of the Cultural Resources Mining Inventory and Monitoring Program: Anchorage, Alaska, National Park Service [in press].

Saltus, R.W., Meyer, J.F., Jr., Barnes, D.F., and Morin, R.L., 1997, Tectono-geophysical domains of interior Alaska as interpreted from new gravity and aeromagnetic data compilations: U.S. Geological Survey Professional Paper 1574, p. 157-171.

Schmoll, H.R., Yehle, L.A., and Dobrovolny, E., 1996, Surficial geologic map of the Anchorage A-8 NE quadrangle, Alaska: U.S. Geological Survey Open-File Report 96003, 49 p., 2 sheets, scale 1:25,000.

Schneider, J.L., ed., 1997, 1996 Annual report on Alaska's mineral resources: U.S. Geological Survey Circular 1142, 70 p.

Shelton, K.L., Underwood, M.B., Burstein, I.B., Heussler, G.T., and Howell, D.G., 1996, Stable isotopic and fluid inclusion studies of hydrothermal quartz and calcite veins from the Kandik thrust belt of east-central Alaska-Implications for thermo-tectonic history and terrane analysis: U.S. Geological Survey Bulletin 2142, p. 111-131.

Sherwood, K.W., Craig, J.D., and Cooke, L.W., 1996, Endowments of undiscovered conventionally recoverable and economically recoverable oil and gas in the Alaska Federal offshore, as of January 1995: Mineral Management Service OCS Report, MMS 96-0033, 17 p.

Smith, T.V., 1995, Coalbed methane potential for Alaska and drilling results for the upper Cook Inlet basin, in Undergoes '95, Proceedings of Symposium, Tuscaloosa, Alabama, p. 21.

Stricker, G.D., and Flores, R.M., 1996, Miocene fluvial-tidal sedimentation in a residual forearc basin of the northeast Pacific Rim-Cook Inlet, Alaska case study [abs.]: American Association of Petroleum Geologists Annual Meeting, San Diego, California, May 19-22, 1996, 1996
Annual Convention Official Program, p. A135.

Swainbank, R.C., Bundtzen, T.K., Clough, A.H., and Henning, M.W., 1997, Alaska's mineral industry 1996: Alaska Division of Geological and Geophysical Surveys Special Report $51,68 \mathrm{p}$.

Trainor, T.P., Fleisher, S., Wildeman, T.R., Goldfarb, R.J., and Huber, C.S., 1996, Environmental geochemistry of the McKinley Lake gold mining district, Chugach National Forest, Alaska: U.S. Geological Survey Bulletin 2152, p. 47-57.

Treacy, S.D., 1996, Aerial surveys of endanged whales in the Beaufort Sea, Fall 1995: Minerals Management Service OCS Study, MMS 96-0006, $130 \mathrm{p}$.

Underwood, M.B., Howell, D.G., Johnsson, M.J., and Pawlewicz, M.J., 1996, Thermo-tectonic evolution of suspect terranes in the Kandik region of east-central Alaska: U.S. Geological Survey Bulletin 2142, p. 81-110.

Underwood, T.J., Gordon, J.A., Millard, M.J., Thorpe, L.A., and Osborne, B.M., 1995, Characteristics of selected fish populations of Arctic National Wildlife Refuge coastal waters, final report, 1988-1991: Fairbanks, Alaska, U.S. Fish and Wildlife Service, Fairbanks Fishery Resource Office, Alaska Fisheries Technical Report 28, 590 p.

Underwood, T.J., Millard, M.J., and Thorpe, L.A., 1996, Relative abundance, length frequency, age, and maturity of Dolly Varden in nearshore waters of the Arctic National Wildlife Refuge, Alaska: Transactions of the American Fisheries Society, v. 125, p. 719-728.

U.S. Department of Energy, 1993, Final Environmental Impact Statement for the proposed Healy Clean Coal Project: Pittsburgh Energy Technology Center, DOE/EIS-0186, $1,100 \mathrm{p}$.

U.S. Fish and Wildlife Service, 1995, A preliminary review of the Arctic National Wildlife Refuge, Alaska, coastal plain resource assessment-Report and recommendations to the Congress of the United States and Final Legislative Environmental Impact Statement: Washington, D.C., U.S. Fish and Wildlife Service, $20 \mathrm{p}$.

U.S. Geological Survey, 1995a, 1995 National assessment of United States oil and gas resources: U.S. Geological Survey Circular 1118, 20 p.

1995b, Wrestling with uncertainty-The 1995 National assessment of United States oil and gas resources: U.S. Geological Survey video.

1996, Alaska Resource Data File-Explanation of fields used in the Alaska Resource Data File of mines, prospects, and mineral occurrences in Alaska: U.S. Geological Survey Open-File Report 96-79, 4 p.

Weast, R.C., ed., 1974, Handbook of chemistry and physics, 55th edition: Cleveland OH, CRC Press, p. F-284.

Werdon, M.B., Newberry, R.J., Burns, L.E., and Mull, C.G., 1996, Probabilistic estimate of mineral resources in the Colville Mining District, Alaska: Alaska Division of Geological and Geophysical Surveys Report of Investigations 96-5, $33 \mathrm{p}$. 
White, W.H., Christie, J.S., Wolfhard, M.R., and Wilson, F.H., 1996, Geology of the Pyramid porphyry copper deposit, Alaska Peninsula, Alaska: U.S. Geological Survey Miscellaneous Field Studies Map 2155-F, p. 30-39.

White, W.H., and Queen, L.D., 1996, Description of the Shumagin epithermal gold vein deposit: U.S. Geological Survey Miscellaneous Field Studies Map MF-2155-F, p. 40-44.

Wilson, F.H., 1996, Alaska Resource Data File-Unalaska quadrangle: U.S. Geological Survey Open-File Report 96-270, 48 p.

Wilson, F.H., and Light, T.D., 1996, Alaska Resource Data File-
Adak quadrangle: U.S. Geological Survey Open-File Report 96-269, 12 p.

Wilson, F.H., White, W.H., Detterman, R.L., and Case, J.E., 1996, Maps showing the resource assessment of the Port Moller, Stepovak Bay, and Simeonof Island quadrangles, Alaska, Peninsula: U.S. Geological Survey Miscellaneous Field Studies Map MF- 2155-F, 46 p., 2 sheets, scales 1:500,000 and 1:250,000.

Yeend, W.E., 1996, Gold placers of the historical Fortymile River region, Alaska: U.S. Geological Survey Bulletin 2125, 75 p., 1 sheet, scale 1:63,360. 



\section{ROLES OF FEDERAL AGENCIES IN MINERAL PROGRAMS}

\section{U.S. DEPARTMENT OF THE INTERIOR U.S. GEOLOGICAL SURVEY}

The mission of the USGS is to develop and interpret the geologic, topographic, and hydrologic data necessary for prudent management of the Nation's minerals, land, and water. The USGS carries out its mission through research that produces geographic, cartographic, and remotely sensed information; geologic, geochemical, and geophysical maps and studies; energy-, mineral, and water-resource assessments; and geohazards assessments, including environmental contaminant studies. Other mission work includes participation in multidisciplinary projects, maintenance of data bases, and publication of reports and maps.

Among other geologic activities in Alaska, the USGS is active in assessing the mineral potential of Federal lands in the State. Field and laboratory personnel gather information about petroleum, coal, metalliferous, and industrial mineral resources. Research and assessments are aimed at understanding the occurrence, quality, quantity, and environmental characteristics of mineral resources; understanding the fundamental processes that create and modify them; developing objective models for assessing the Nation's mineral-resource endowment; understanding the life cycle of energy and nonfuel minerals; and predicting the potential environmental impacts of mineral development. At the request of land-managing agencies, the USGS provides mineral-resource assessments, including wilderness studies, for land-planning purposes.

Within Alaska, the USGS maintains offices for its Geologic, National Mapping, Water Resources, and Biological Resources Divisions. Within the recently reorganized Geologic Division, the Alaska Section is the primary USGS office studying mineral resources in Alaska. The Alaska Section is part of the MRP Western Region Team, one of three regional minerals teams that assist the national program coordinator in Reston, Virginia, to prioritize and carry out the objectives of the USGS minerals program. The section is headquartered in Anchorage, and additional Alaska Section geoscientists are stationed in Menlo Park, California, and Denver, Colorado. Personnel of the ERP who work in Alaska are also stationed in Menlo Park and Denver.

\section{BUREAU OF LAND MANAGEMENT}

The BLM was created in 1946 by the merger of the General Land Office and the Grazing Service; its function was to continue the work of the two former agencies. In 1976, under the Federal Land Policy and Management Act, the BLM was given responsibility for the management of mining claims on all Federal lands and responsibility for ensuring environmentally sound mineral development on BLM lands. In 1984, the BLM was given responsibility for onshore leasable mineral activities. The BLM works cooperatively with the FWS, NPS, and FS to provide technical evaluation of mineral-related issues on lands managed by these agencies.

BLM-Alaska's mineral activities are addressed at several organizational levels. Leasable minerals are oil, gas, coal, phosphate, oil shale, and uranium. The BLM manages onshore leasable minerals for all Federal lands in Alaska and is responsible for leasehold operations. The BLM holds lease sales, conducts resource assessments and economic evaluations, grants permits for development, protects resource drainage, and inspects operations for permit compliance on leases. These activities are carried out by the Energy and Minerals Team in the Anchorage District Office. Locatable minerals are placer and lode deposits which have sufficient value for interested parties to file and patent claims thereupon; salable minerals are sand, gravel, and stone. The District Offices in Anchorage, Fairbanks, and Glennallen determine the value of salable minerals and conducts minerals sales for same. For locatable minerals, the District Offices process mining Plans of Operations and Notices of Intent, perform mineral and patent validity examinations and determinations, and conduct surface compliance inspections to ensure that mining operations are in accordance with stipulated conditions. The BLM State Office adjudicates all mineral patent applications on Federal lands and has technical approval authority for all mineral patent and validity examination reports; patent approval is granted by the Secretary of the Interior. Regional hardrock mineral assessments and mining district studies are administered by the Division of Lands, Minerals, and Resources Information at the Alaska State Office in Anchorage. This division also provides the coordination of all leasable, locatable, and salable minerals activities by Federal landmanagement agencies in Alaska.

Management decisions concerning all mineral estates of the 372,312 square kilometers of land currently managed by the BLM in Alaska (fig. 1) are made through the Resource Management Planning process. Through this process, the BLM identifies and defines planning units, and the mineral potential of each unit is analyzed. Effects of potential minerals exploration, development, production, and reclamation are determined and compared to 
analyses of coexisting cultural and biological resources. The BLM then develops land-management options to minimize adverse or competing land-use proposals involving mineral extraction activities. Active field monitoring of all phases of mineral activities ensures that unnecessary or undue degradation does not occur. The BLM provides similar resource-management information to other agencies for leasable Federal mineral estates on an additional 404,673 square kilometers.

The BLM maintains a professional minerals staff to ensure that minerals adjudication and operations are done in accordance with regulations and BLM management practices and standards. The BLM is also involved with public outreach programs that are incorporated into local school programs and local chapters of mining associations.

\section{MINERALS MANAGEMENT SERVICE}

The MMS was created in 1982 with a twofold mission: (1) to collect and disburse revenues generated from mineral leases on Federal and Indian lands, and (2) to oversee the orderly development of America's offshore energy and mineral resources while properly safeguarding the environment. The MMS supervises mineral leasing, exploration, development, and production on the OCS. It is responsible for oil rig safety, oil rig pollution control regulations, determination of the environmental impact of resource development, and estimation of oil and gas resources. The MMS also has the authority to lease the OCS for ocean mining of hard minerals. At present, revenues from the Alaska OCS are primarily derived from competitive leasing activities; no production is occurring on the OCS at this time. The responsibility of the MMS for onshore Alaskan minerals is limited to the collection of royalties, bonuses, and rents from Federal and certain Native lands.

The MMS holds synthesis meetings, information transfer meetings, regional technical working group meetings, coordination team meetings, and EIS public hearings. To determine public concerns for consideration and inclusion in an EIS, scoping meetings related to specific planning or subject areas are held in the villages local to the area of concern. The public is invited to attend these meetings and can contact the MMS Alaska OCS Region office for specific subjects, dates, and times.

In Alaska, the MMS is active in assessing the oil and gas potential of offshore basins through the analysis of geophysical and geologic data. This work is integrated into the Federal National Oil and Gas Resource Assessment and is a basis for evaluations of the potential monetary worth of individual OCS lease blocks, for appraisals of the resource potential of entire basins, and for the formulation of geologic models of basin development. The MMS conducts specialized studies of geological and geophysical data obtained from COST wells and exploratory wells drilled on OCS lands. The results of these studies are published through the MMS OCS Report series or in appropriate scientific journals. The MMS also sponsors resourceoriented geologic studies through the Program for Studies Related to Continental Margins, which funds research by State agencies and affiliated academic institutions.

\section{NATIONAL PARK SERVICE}

In 1916, Congress established the National Park Service and stated in its Organic Act that the fundamental purpose of the Nation's parks, monuments, and other reservations was "to conserve the scenery and natural and historic objects and wildlife therein and to provide for the enjoyment of the same in such manner and by such means as will leave them unimpaired for the enjoyment of future generations" [39 Stat. 535, NPS Organic Act]. NPS management policies are based on the concept of ecosystem stewardship, conservation, and preservation, while providing for appropriate public enjoyment of the natural and cultural resources within individual units of the National Park System.

Congress enacted the Mining in the Parks Act in 1976, declaring that the continued application of the Mining Law of 1872 on park lands conflicted with the purposes for which parks were established. The act closed all park lands to further mineral entry and stipulated that mining operations with prior existing rights “....be conducted so as to prevent or minimize damage to the environment and other resource values" [90 Stat. 1342].

The passage of ANILCA in 1980 increased NPS involvement with minerals-management issues. ANILCA expanded the National Park System in Alaska (fig. 3) to over 206,391 square kilometers and incorporated over 4,000 unpatented and 1,800 patented mining claims and other private inholdings within park unit boundaries. ANILCA identified specific minerals-management directives for some park units and directed the NPS to permit mineral-resource assessments by other Federal agencies under AMRAP.

The NPS manages mining-related activities on patented and unpatented mining claims via regulations found in 36 CFR 9(a); non-Federal oil and gas development via regulations found in 36 CFR 9(b); and AMRAP program activities via regulations found in 36 CFR 9(d). Since 1990, NPS minerals-management activities in Alaska have been directed by three EIS's on the cumulative impacts of mining in Denali NP\&P, Wrangell-St. Elias NP\&P, and YukonCharley Rivers National Preserve; these EIS's were approved by both the U.S. District Court and 9th Circuit Court. The Records of Decision in the three EIS's directed the NPS to acquire all mining properties within park boundaries, manage all future mining within the stringent guidelines of NPS regulations, and reclaim all lands impacted by mining. Since that decision, the NPS has developed and implemented a claim acquisition program, refined and expanded its claim management program, and developed and implemented a mineral lands restoration program. 


\section{U.S. FISH AND WILDLIFE SERVICE}

The FWS provides Federal leadership to conserve, protect, and enhance fish and wildlife and their habitats for the continuing benefit of people. In Alaska, the FWS seeks to accomplish this mission through programs that implement provisions of the Endangered Species Act, Marine Mammals Protection Act, Fish and Wildlife Coordination Act, National Wildlife Refuge System Administration Act, ANILCA, Rivers and Harbors Act, Clean Water Act, various migratory-bird laws and treaties, and other statutes.

Under ANILCA, 16 refuges in Alaska (fig. 4) were created or enlarged to conserve fish and wildlife populations and their habitats, as well as other values. Except for valid rights existing at the time of establishment, these refuges are closed to entry and location under mining laws. Excepting Arctic NWR, the refuges are open to entry under leasing laws but are closed to oil and gas leasing by Secretarial discretion [43 CFR 3101.5(b)], and to mining of coal by the Federal Coal Leasing Amendments Act of 1975. Refuges are closed to geothermal resource leasing by the Geothermal Steam Act of 1970 . Although many traditional activities have been deemed appropriate for these refuges, any uses will be permitted only when such activities are compatible with the purposes for which a specific refuge was established.

\section{U.S. DEPARTMENT OF ENERGY}

DOE's mission is to reduce the Nation's vulnerability to disruptions of energy supplies and to mitigate any adverse impacts on the Nation should a shortage occur. With regard to Alaska, resources currently being addressed by the DOE are the fossil fuels (petroleum, natural gas, and coal) and geothermal energy.

The strategy for responding to petroleum-supply interruptions is to rely on the free market, supplemented as necessary and appropriate with other measures, such as the Strategic Petroleum Reserve. DOE's Fossil Energy Research and Development Programs are aimed at careful consideration of the alternatives available and the relative chances for success in fostering an adequate supply of energy at a reasonable cost through long-term, high-risk research and development. Alternatives for increasing domestic petroleum supplies include (1) DOE's Natural Gas Technology Program, which emphasizes the development of advanced technologies for the extraction of natural gas from resources that are classified as nonconventional due to unique geologic settings and production mechanisms that are not now well understood, and (2) various DOE programs for developing tertiary oil recovery, tar sands, and heavy-oil deposits. DOE's cooperative research and development agreement with BPX for heavy-oil recovery on Alaska's North Slope is the first industrial partnership dealing with oil production concerns, and it is hoped that similar partnerships will be developed in the future.

The Clean Coal Technology Program is a partnership between the DOE and industry that has as its primary goal the successful demonstration of a new generation of advanced coalbased technologies and the resultant movement of the most promising technologies into the domestic and international marketplace. The demonstrations are at a scale large enough to generate the data needed to enable potential domestic and international users to make judgments about the commercial viability of a particular process. These technologies will improve the global environment and enhance global energy security through the use of systems and services provided by United States' industry.

The purpose of the DOE's Geothermal Energy Program is to develop the technology needed by industry for the use of geothermal resources. DOE research is aimed toward improving methods used to locate, extract, and convert geothermal heat to usable forms of energy. Through DOE funding in Alaska, Federal and State agencies have researched and published several studies of specific geothermal systems.

\section{U.S. DEPARTMENT OF AGRICULTURE}

\section{FOREST SERVICE}

The mission of the FS in relation to minerals management is to encourage, facilitate, and administer the orderly exploration, development, and production of mineral and energy resources on NFS lands to help meet the present and future needs of the Nation. It is the responsibility of the FS to encourage and support environmentally sound mineral enterprises on Federal lands under its administration. In managing the use of these resources, the FS objective is to minimize unnecessary adverse environmental impacts to surface and cultural features and values that might result from lawful exploration and development operations. This objective is accomplished through the application of reasonable conditions that do not interfere with well-planned mineral operations. The FS also provides research information and technology to help with postmining reclamation. In implementing this policy, the FS Chief directed that minerals-management professionals:

1. Process applications and other use authorizations efficiently and in a timely manner.

2. Ensure the integration of mineral-resource programs with the planning process, recognizing that mineral development can occur concurrently or sequentially with other resource uses.

3. Plan and provide for access to all NFS lands open to mineral entry; eliminate or prevent occupancy that is not reasonably 
incident to, and required for, the mineral operation; ensure that valid existing rights have been established before allowing mineral or energy activities on NFS lands withdrawn from mineral entry.

4. Ensure that the mineral character or potential of lands considered for administrative withdrawal from mineral entry are thoroughly evaluated for the value of the resource foregone, and ensure that only certified mineral examiners perform site visits and prepare reports that address the mineral or geologic character of the subject lands.

5. Coordinate with all Federal, State and local agencies having authority and expertise in minerals-related activities.

6. Maintain a professional administrative, technical, and managerial work force that is knowledgeable in FS mineralsmanagement responsibilities and activities.

7. Ensure the uniform application of exploration, development, reclamation, and monitoring standards, and require, for all mineral activities involving significant surface disturbance, a bond and reclamation plan to return the land to other productive uses consistent with FS minerals-management and land-use planning goals. 


\section{LISTING OF USGS CIRCULARS IN ANILCA SECTION 1011 ANNUAL MINERAL REPORT SERIES}

Schneider, J.L., ed., 1998, 1997 Annual report on Alaska's mineral resources: U.S. Geological Survey Circular 1154, 67p. _ 1997, 1996 Annual report on Alaska's mineral resources: U.S. Geological Survey Circular 1142, 70 p.

1995, 1995 Annual report on Alaska's mineral resources: U.S. Geological Survey Circular 1127, 67 p.

1994, 1994 Annual report on Alaska's mineral resources: U.S.

Geological Survey Circular 1113, 69 p.

1993, 1993 Annual report on Alaska's mineral resources: U.S.

Geological Survey Circular 1102, 70 p.

Bohn, D., and Schneider, J.L., eds., 1992, 1992 Annual report on Alaska's mineral resources: U.S. Geological Survey Circular 1091, 65 p.

Schneider, J.L., ed., 1991, 1991 Annual report on Alaska's mineral resources: U.S. Geological Survey Circular 1072, 69 p. -1990, 1990 Annual report on Alaska's mineral resources: U.S. Geological Survey Circular 1056, 67 p.
—1989, 1989 Annual report on Alaska's mineral resources: U.S. Geological Survey Circular 1040, 70 p.

Bohn, Diedra, ed., 1988, 1988 Annual report on Alaska's mineral resources: U.S. Geological Survey Circular 1023, 57 p.

—1987, 1987 Annual report on Alaska's mineral resources: U.S. Geological Survey Circular 1012, 59 p.

U.S. Geological Survey, 1986, 1986 Annual report on Alaska's mineral resources: U.S. Geological Survey Circular 983, $47 \mathrm{p}$.

1985, 1985 Annual report on Alaska's mineral resources: U.S. Geological Survey Circular 970, 58 p.

1984, 1984 Annual report on Alaska's mineral resources: U.S. Geological Survey Circular 940, 54 p.

1983, 1983 Annual report on Alaska's mineral resources: U.S. Geological Survey Circular 908, 48 p.

1982, 1982 Annual report on Alaska's mineral resources: U.S. Geological Survey Circular 884, 59 p. 



\section{Selected Series of U.S. Geological Survey Publications}

\section{Books and Other Publications}

Professional Papers report scientific data and interpretations of lasting scientific interest that cover all facets of USGS investigations and research.

Bulletins contain significant data and interpretations that are of lasting scientific interest but are generally more limited in scope or geographic coverage than Professional Papers.

Water-Supply Papers are comprehensive reports that present significant interpretive results of hydrologic investigations of wide interest to professional geologists, hydrologists, and engineers. The series covers investigations in all phases of hydrology, including hydrogeology, availability of water, quality of water, and use of water.

Circulars are reports of programmatic or scientific information of an ephemeral nature; many present important scientific information of wide popular interest. Circulars are distributed at no cost to the public.

Fact Sheets communicate a wide variety of timely information on USGS programs, projects, and research. They commonly address issues of public interest. Fact Sheets generally are two or four pages long and are distributed at no cost to the public.

Reports in the Digital Data Series (DDS) distribute large amounts of data through digital media, including compact discread-only memory (CD-ROM). They are high-quality, interpretive publications designed as self-contained packages for viewing and interpreting data and typically contain data sets, software to view the data, and explanatory text.

Water-Resources Investigations Reports are papers of an interpretive nature made available to the public outside the formal USGS publications series. Copies are produced on request (unlike formal USGS publications) and are also available for public inspection at depositories indicated in USGS catalogs.

Open-File Reports can consist of basic data, preliminary reports, and a wide range of scientific documents on USGS investigations. Open-File Reports are designed for fast release and are available for public consultation at depositories.

\section{Maps}

Geologic Quadrangle Maps (GQ's) are multicolor geologic maps on topographic bases in 7.5- or 15-minute quadrangle formats (scales mainly 1:24,000 or 1:62,500) showing bedrock, surficial, or engineering geology. Maps generally include brief texts; some maps include structure and columnar sections only.

Geophysical Investigations Maps (GP's) are on topographic or planimetric bases at various scales. They show results of geophysical investigations using gravity, magnetic, seismic, or radioactivity surveys, which provide data on subsurface structures that are of economic or geologic significance.
Miscellaneous Investigations Series Maps or Geologic Investigations Series (I's) are on planimetric or topographic bases at various scales; they present a wide variety of format and subject matter. The series also incudes 7.5-minute quadrangle photogeologic maps on planimetric bases and planetary maps.

\section{Information Periodicals}

Metal Industry Indicators (MII's) is a free monthly newsletter that analyzes and forecasts the economic health of five metal industries with composite leading and coincident indexes: primary metals, steel, copper, primary and secondary aluminum, and aluminum mill products.

Mineral Industry Surveys (MIS's) are free periodic statistical and economic reports designed to provide timely statistical data on production, distribution, stocks, and consumption of significant mineral commodities. The surveys are issued monthly, quarterly, annually, or at other regular intervals, depending on the need for current data. The MIS's are published by commodity as well as by State. A series of international MIS's is also available.

Published on an annual basis, Mineral Commodity Summaries is the earliest Government publication to furnish estimates covering nonfuel mineral industry data. Data sheets contain information on the domestic industry structure, Government programs, tariffs, and 5-year salient statistics for more than 90 individual minerals and materials.

The Minerals Yearbook discusses the performance of the worldwide minerals and materials industry during a calendar year, and it provides background information to assist in interpreting that performance. The Minerals Yearbook consists of three volumes. Volume I, Metals and Minerals, contains chapters about virtually all metallic and industrial mineral commodities important to the U.S. economy. Volume II, Area Reports: Domestic, contains a chapter on the minerals industry of each of the 50 States and Puerto Rico and the Administered Islands. Volume III, Area Reports: International, is published as four separate reports. These reports collectively contain the latest available mineral data on more than 190 foreign countries and discuss the importance of minerals to the economies of these nations and the United States.

\section{Permanent Catalogs}

"Publications of the U.S. Geological Survey, 1879-1961" and "Publications of the U.S. Geological Survey, 19621970" are available in paperback book form and as a set of microfiche.

"Publications of the U.S. Geological Survey, 1971-1981" is available in paperback book form (two volumes, publications listing and index) and as a set of microfiche.

Annual supplements for 1982, 1983, 1984, 1985, 1986, and subsequent years are available in paperback book form. 


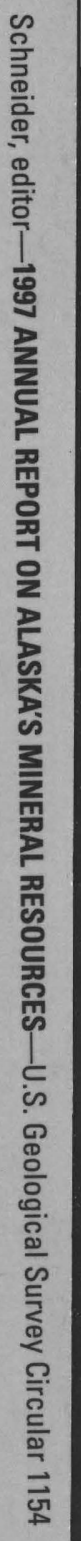

ISBN 0-607-97เ15-X

||| |||||||||||||||| ||||||| 